Prepared in cooperation with the Sisseton Wahpeton Oyate

Characterization of Factors Affecting Groundwater Levels in and near the Former Lake Traverse Indian Reservation, South Dakota, Water Years 1956-2017

Scientific Investigations Report 2020-5151 



\section{Characterization of Factors Affecting Groundwater Levels in and near the Former Lake Traverse Indian Reservation, South Dakota, Water Years 1956-2017}

By Kristen J. Valseth and Daniel G. Driscoll

Prepared in cooperation with the Sisseton Wahpeton Oyate

Scientific Investigations Report 2020-5151 


\section{U.S. Geological Survey, Reston, Virginia: 2021}

For more information on the USGS - the Federal source for science about the Earth, its natural and living resources, natural hazards, and the environment—visit https://www.usgs.gov or call 1-888-ASK-USGS.

For an overview of USGS information products, including maps, imagery, and publications, visit https://store.usgs.gov/.

Any use of trade, firm, or product names is for descriptive purposes only and does not imply endorsement by the U.S. Government.

Although this information product, for the most part, is in the public domain, it also may contain copyrighted materials as noted in the text. Permission to reproduce copyrighted items must be secured from the copyright owner.

Suggested citation:

Valseth, K.J., and Driscoll, D.G., 2021, Characterization of factors affecting groundwater levels in and near the former Lake Traverse Indian Reservation, South Dakota, water years 1956-2017: U.S. Geological Survey Scientific Investigations Report 2020-5151, 64 p., https://doi.org/10.3133/sir20205151.

Associated data:

U.S. Geological Survey, 2019, USGS water data for the Nation: U.S. Geological Survey National Water Information System database, https://doi.org/10.5066/F7P55KJN.

ISSN 2328-0328 (online) 


\section{Contents}

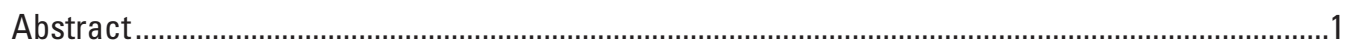

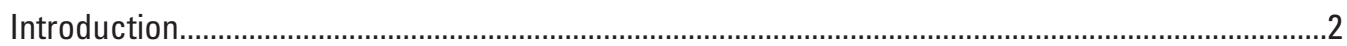

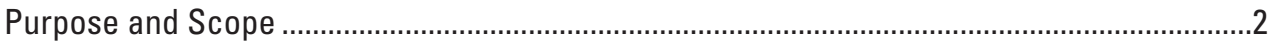

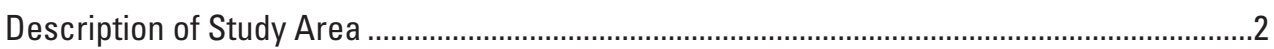

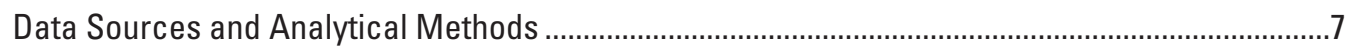

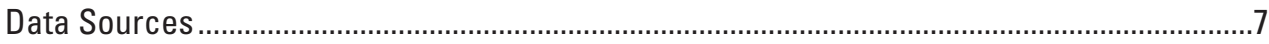

Climate Data............................................................................................................

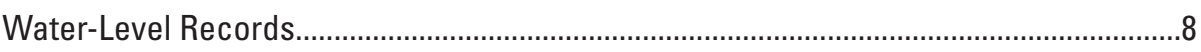

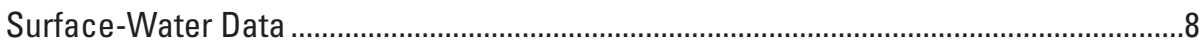

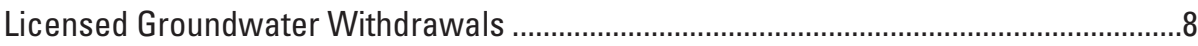

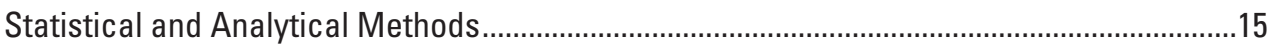

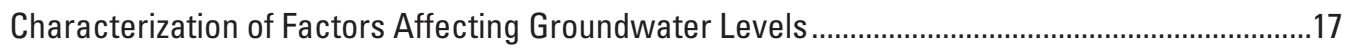

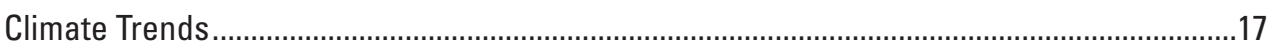

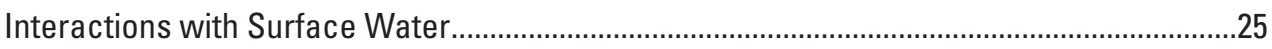

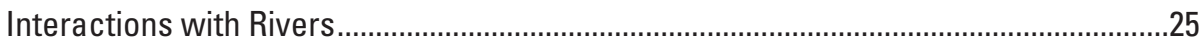

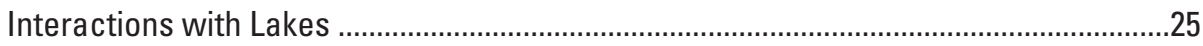

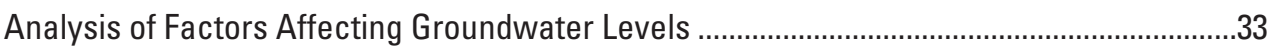

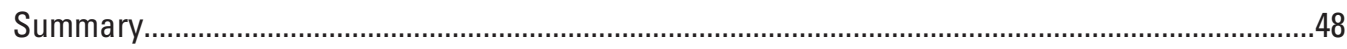

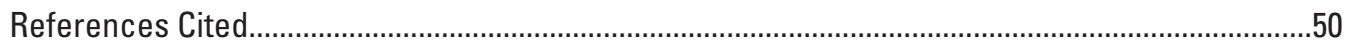

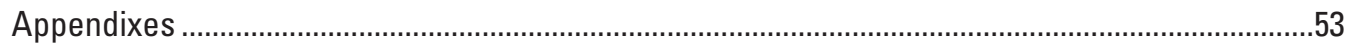

\section{Figures}

1. Map showing location of the study area, observation wells, lakes, streamgages, extents of select aquifers, and the historical 1867 boundary of the former Lake Traverse Reservation in northeastern South Dakota and southeastern North Dakota

2. Hydrogeologic section $A-A$ ' showing the Roslyn outwash group and the Veblen, Milnor Channel, Rosholt, and Fairmount aquifers or aquifer systems in

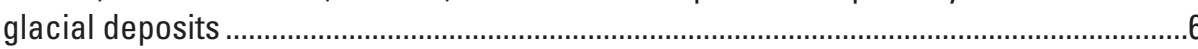

3. Maps showing locations of licensed groundwater withdrawals within the study area, relative to locations of observations wells

4. Graph showing summary of groundwater withdrawals over time for the study area ....14

5. Graphs showing example analysis that includes three graphs showing trends in measured groundwater levels and annual precipitation totals, lake levels for a selected lake, and proximal groundwater withdrawals for observation well DA-78C

6. Maps showing spatial distribution of statistically significant trends in annual climate data within the study area, water years 1956-2017.

7. Maps showing spatial distribution of statistically significant trends in seasonal (October-December) climate data within the study area, water years 1956-2017.........19

8. Maps showing spatial distribution of statistically significant trends in seasonal (January-March) climate data within the study area, water years 1956-2017

9. Maps showing spatial distribution of statistically significant trends in seasonal (April-June) climate data within the study area, water years 1956-2017 
10. Maps showing spatial distribution of statistically significant trends in seasonal (July-September) climate data within the study area, water years 1956-2017..............22

11. Graphs showing annual total precipitation and departures from mean for the study area, water years 1956-2017.......

12. Graphs showing annual total precipitation and departures from mean for the study area, water years 1896-2017.

13. Hydrographs of annual mean streamflow for selected streamgages within the study area

14. Hydrographs of measured lake levels for selected lakes within the study area.............30

15. Map showing wells completed in the North Big Sioux aquifer with statistically significant trends for at least one water-level parameter.

16. Map showing wells completed in the Prairie Coteau outwash group with statistically significant trends for at least one water-level parameter

17. Map showing wells completed in the Coteau Lakes aquifer system with statistically significant trends for at least one water-level parameter.....

18. Map showing wells completed in the Veblen aquifer with statistically significant trends for at least one water-level parameter

19. Map showing wells completed in the Fairmount aquifer with statistically significant trends for at least one water-level parameter.

20. Map showing wells completed in the Revillo aquifer with statistically significant trends for at least one water-level parameter

21. Map showing wells completed in the Rosholt aquifer with statistically significant trends for at least one water-level parameter

\section{Tables}

1. Summary of water use for calendar year 2015 for selected major categories for South Dakota counties in the study area.

2. Summary of selected characteristics for glacial aquifers and named glacial outwash groups within the study area. .5

3. Selected site information for observation wells within the study area............................9

4. Site information for selected streamgages within the study area .................................11

5. Site information for selected lakes with water-level records within the study area ......11

6. Results of trend analyses for annual total precipitation for the study area for three time periods.

7. Correlation matrix of annual median water level for observation wells versus annual mean streamflow for streamgages

8. Correlation coefficients for annual median and annual maximum water levels for observation wells versus annual median water level for selected lakes... .26

9. Correlation matrix for annual median lake levels for selected lakes

10. Summary of results of trend analyses for water levels and annual total precipitation at observation wells 


\section{Conversion Factors}

U.S. customary units to International System of Units

\begin{tabular}{|c|c|c|}
\hline Multiply & By & To obtain \\
\hline \multicolumn{3}{|c|}{ Length } \\
\hline inch (in.) & 2.54 & centimeter $(\mathrm{cm})$ \\
\hline inch (in.) & 25.4 & millimeter (mm) \\
\hline foot $(\mathrm{ft})$ & 0.3048 & meter \\
\hline mile (mi) & 1.609 & kilometer $(\mathrm{km})$ \\
\hline \multicolumn{3}{|c|}{ Area } \\
\hline square mile $\left(\mathrm{mi}^{2}\right)$ & 2.590 & square kilometer $\left(\mathrm{km}^{2}\right)$ \\
\hline \multicolumn{3}{|c|}{ Flow rate } \\
\hline cubic foot per second $\left(\mathrm{ft}^{3} / \mathrm{s}\right)$ & 0.02832 & cubic meter per second $\left(\mathrm{m}^{3} / \mathrm{s}\right)$ \\
\hline gallon per minute (gal/min) & 0.06309 & liter per second $(\mathrm{L} / \mathrm{s})$ \\
\hline million gallons per day (Mgal/d) & 0.04381 & cubic meter per second $\left(\mathrm{m}^{3} / \mathrm{s}\right)$ \\
\hline million gallons per day (Mgal/d) & 1.54723 & cubic foot per second $\left(\mathrm{ft}^{3} / \mathrm{s}\right)$ \\
\hline inch per year (in/yr) & 25.4 & millimeter per year (mm/yr) \\
\hline
\end{tabular}

\section{Datum}

Vertical coordinate information is referenced to the National Geodetic Vertical Datum of 1929 (NGVD 29) unless otherwise specified.

Horizontal coordinate information is referenced to the North American Datum of 1983 (NAD 83) unless otherwise specified.

Elevation, as used in this report, refers to distance above the vertical datum.

\section{Supplemental Information}

Water year (WY) is the 12-month period, October 1 through September 30, and is designated by the calendar year in which it ends. 


\section{Abbreviations}

$\begin{array}{ll}\text { LOESS } & \text { locally estimated scatterplot smoothing } \\ p \text {-value } & \text { probability value } \\ \text { PRISM } & \text { Parameter-elevation Regressions on Independent Slopes Model } \\ \text { SDDENR } & \text { South Dakota Department of Environment and Natural Resources } \\ \text { STP } & \text { short-term persistence } \\ \text { SWO } & \text { Sisseton Wahpeton Oyate } \\ \tau & \text { tau from Kendall's tau nonparametric test } \\ T_{\max } & \text { maximum air temperature } \\ T_{\min } & \text { minimum air temperature } \\ \text { USGS } & \text { U.S. Geological Survey } \\ \text { WY } & \text { water year }\end{array}$




\title{
Characterization of Factors Affecting Groundwater Levels in and near the Former Lake Traverse Indian Reservation, South Dakota, Water Years 1956-2017
}

\author{
By Kristen J. Valseth and Daniel G. Driscoll
}

\section{Abstract}

The U.S. Geological Survey (USGS), in cooperation with the Sisseton Wahpeton Oyate, completed a study to characterize water-level fluctuations in observation wells relative to driving factors that affect water levels in and near the historical 1867 boundary of the Lake Traverse Indian Reservation. The study investigated concerns regarding potential effects of groundwater withdrawals and climate conditions on groundwater levels within an area that includes the historical boundary of the reservation and a surrounding area that extends 10 miles in all directions within South Dakota. Characterization of water-level fluctuations in observation wells and relative driving factors was accomplished by statistical trend analysis.

Monthly data from the Parameter-elevation Regressions on Independent Slopes Model (PRISM) were aggregated to obtain annual and seasonal datasets for total precipitation, minimum air temperature $\left(T_{\min }\right)$, and maximum air temperature $\left(T_{\max }\right)$ for the study area and a surrounding buffer area. Trend tests for gridded data for total precipitation, $T_{\min }$, and $T_{\max }$ were completed for annual and seasonal time series for water years 1956-2017, which is about 2 years before the earliest available water-level measurements. A 2-year offset was arbitrarily selected because scrutiny of water-level and precipitation data indicated that responses of groundwater levels for many of the observation wells lagged major changes in precipitation patterns by about 2 years. Statistically significant upward trends were detected for annual precipitation and annual $T_{\min }$ for most of the study area and the surrounding buffer area. Statistically significant downward trends in $T_{\max }$ were detected for only a few 2.5 arc-minute grid cells; however, the sparsity of the spatial coverage reduces confidence that these are true trends, in contrast to the near completeness of the spatial coverage in upward trends for $T_{\min }$. Spatial distributions of statistically significant trends in seasonal climate data were generally similar to the annual trends, but with substantial differences in the spatial density of the trends.

Potential interactions among water levels in observation wells and streamflow were examined through correlation analyses of the annual median water level for each of 76 observation wells versus the annual mean streamflow for each of four area streamgages. Potential interactions among water levels in observation wells and lake levels were examined through correlation analyses involving 25 area lakes. Resulting correlation coefficients were used as part of an approach for selecting a lake to be plotted in conjunction with water-level and precipitation data for each observation well.

Groundwater trends for 76 observation wells were analyzed for three separate water-level parameters (minimum, median, and maximum) because wells are measured sporadically, and data are biased towards more frequent measurements during periods of heaviest irrigation demand. Trends in the time series of annual precipitation (from PRISM) starting 2 years earlier than the associated water-level trend also were analyzed for the location of each individual observation well. Sen's slope and Mann-Kendall $p$-values were computed for the three water-level parameters and for the annual precipitation time series. Graphs showing results of trend analyses for each observation well also showed changes with time in the sum of licensed groundwater withdrawals within six specified radii $(0.5,1.0,2.0,3.0,4.0$, and 5.0 miles) of each well as a qualitative indicator of proximal groundwater demand.

Trends in groundwater levels in observation wells in the study area are predominantly upward, with 43 of 76 wells having significant upward trends for at least one of the three water-level parameters and only 8 wells having significant downward trends for at least one water-level parameter. The upward groundwater trends are driven by predominantly upward precipitation trends, with 43 wells (not all the same wells) also having significant upward trends and no wells having significant downward trends. Significant upward precipitation trends were detected for only two of the eight wells with significant downward groundwater trends. Groundwater levels in some observation wells likely are also substantially affected by interactions with surface water, especially with lakes. Water levels in many area lakes increased in response to wet conditions of the early 1990s and have maintained high water levels ever since. It is recognized that in many cases lakes that were selected for plotting with groundwater hydrographs likely are not hydraulically connected with a groundwater system or 
aquifer associated with an individual well; however, interactions also are plausible for numerous other lakes for which water-level records are not available.

\section{Introduction}

There are many extensive and complex interconnections between surface-water and groundwater resources in the Prairie Potholes Region of northeastern South Dakota and southeastern North Dakota, which is home to the Sisseton Wahpeton Oyate (SWO). The historical 1867 boundary of the Lake Traverse Indian Reservation, which was established by the Lake Traverse Treaty of 1867, is shown in figure 1 (Sisseton Wahpeton Oyate, 2019). Numerous glacial aquifers exist along and near the Coteau des Prairies (fig. 1), a prominent glacial feature (Martin and others, 2004) where a myriad of wetlands and lakes are interspersed with farmland and pastureland. In recent years, increasing commodity prices have driven the agricultural industry towards more intensive agricultural practices aimed at increased crop production, which has potential to increase irrigation demand. The SWO is concerned about potential effects of groundwater withdrawals and climate conditions on water levels in area aquifers, which are critical for municipal, domestic, and agricultural water supplies. To help address these concerns, the U.S. Geological Survey (USGS), in cooperation with the SWO, completed a study to characterize water-level fluctuations in observation wells to examine driving factors that affect water levels in and near the former Lake Traverse Indian Reservation. The results of this study can be used to identify areas of groundwater change that may require further investigation and to identify areas with limited data that could be enhanced with data collection tools, such as real-time well recorders.

The State of South Dakota has jurisdiction for issuing water rights for non-Tribal lands, which are interspersed with Tribal lands within the historical boundary of the reservation. The SWO historically has had water-rights jurisdiction only for Tribal lands.

\section{Purpose and Scope}

The purpose of this report is to describe trends in groundwater level fluctuations in observation wells relative to selected driving factors that affect groundwater levels in and near the former Lake Traverse Reservation. The study area (fig. 1) includes the historical boundary of the reservation and a surrounding area that extends 10 miles (mi) in all directions within South Dakota. Driving factors considered that affect groundwater levels include climate conditions, interactions with surface water, and groundwater withdrawals. Temporal trends were analyzed for water-level records during 1957-2017 for 76 observation wells operated by the South Dakota Department of Environment and Natural Resources (SDDENR) and for estimated precipitation at the well locations. Interactions with surface water (rivers and lakes) and groundwater withdrawals within $5 \mathrm{mi}$ of each observation well also are qualitatively considered as driving factors. Development of quantitative relations among water levels and driving factors is beyond the scope of the study; however, results of the study could inform future efforts to do so.

\section{Description of Study Area}

The study area (fig. 1) includes the historical 1867 boundary of the former Lake Traverse Reservation and a surrounding buffer area that extends $10 \mathrm{mi}$ in all directions within South Dakota. The historical boundary of the reservation includes most of Roberts County and parts of Codington, Day, Grant, and Marshall Counties in South Dakota. The small parts of Richland and Sargent Counties in North Dakota are excluded from the study area.

Land use within the study area is largely driven by a combination of topography and surficial/soil conditions. Data regarding area soil surveys are available from an online database hosted by the U.S. Department of Agriculture Natural Resources Conservation Service (2019). Agriculture is the largest land use, with numerous crops grown in areas that are suitable for cultivation. Irrigation systems, most typically using sprinkler systems (Carter and Neitzert, 2008), have been developed in a small percentage of cultivated fields. Grazing and hay land are the most typical agricultural land uses in areas where cultivation is precluded by several glacially influenced factors that can include rocky soils, steep topography, and a myriad of wetlands.

A perspective on irrigation usage and other major groundwater usage is provided by table 1 , which summarizes major water-use categories during 2015 for the counties in the South Dakota portion of the study area, as reported by Dieter and others (2018). As a comparison, table 1 also shows reported usage for Minnehaha and Spink Counties, which have the largest groundwater usage for public supply and irrigation in South Dakota, respectively. Combined groundwater usage for all five counties in the study area was only 16.42 million gallons per day, which is less than for Minnehaha County, which is dominated by public supply, and Spink County, which is dominated by irrigation. Only 0.60 percent of the combined area for the five South Dakota counties in the study area is irrigated, compared to 2.65 percent for Spink County.

Water resources of the former reservation and the rest of Roberts County were described in detail by Thompson (2001), whose work followed an earlier water-resource appraisal of the reservation by Lawrence (1989). Thompson (2001) described 11 glacial aquifers and 6 named glacial outwash groups (table 2) that are considered aquifers within the study area. Thompson (2001) and Lawrence (1989) also described physiography and climate within the former reservation and the rest of Roberts County. Descriptions of hydrogeology, physiography, and climate for other counties partially within the study area in South Dakota were provided by Koch (1972, 


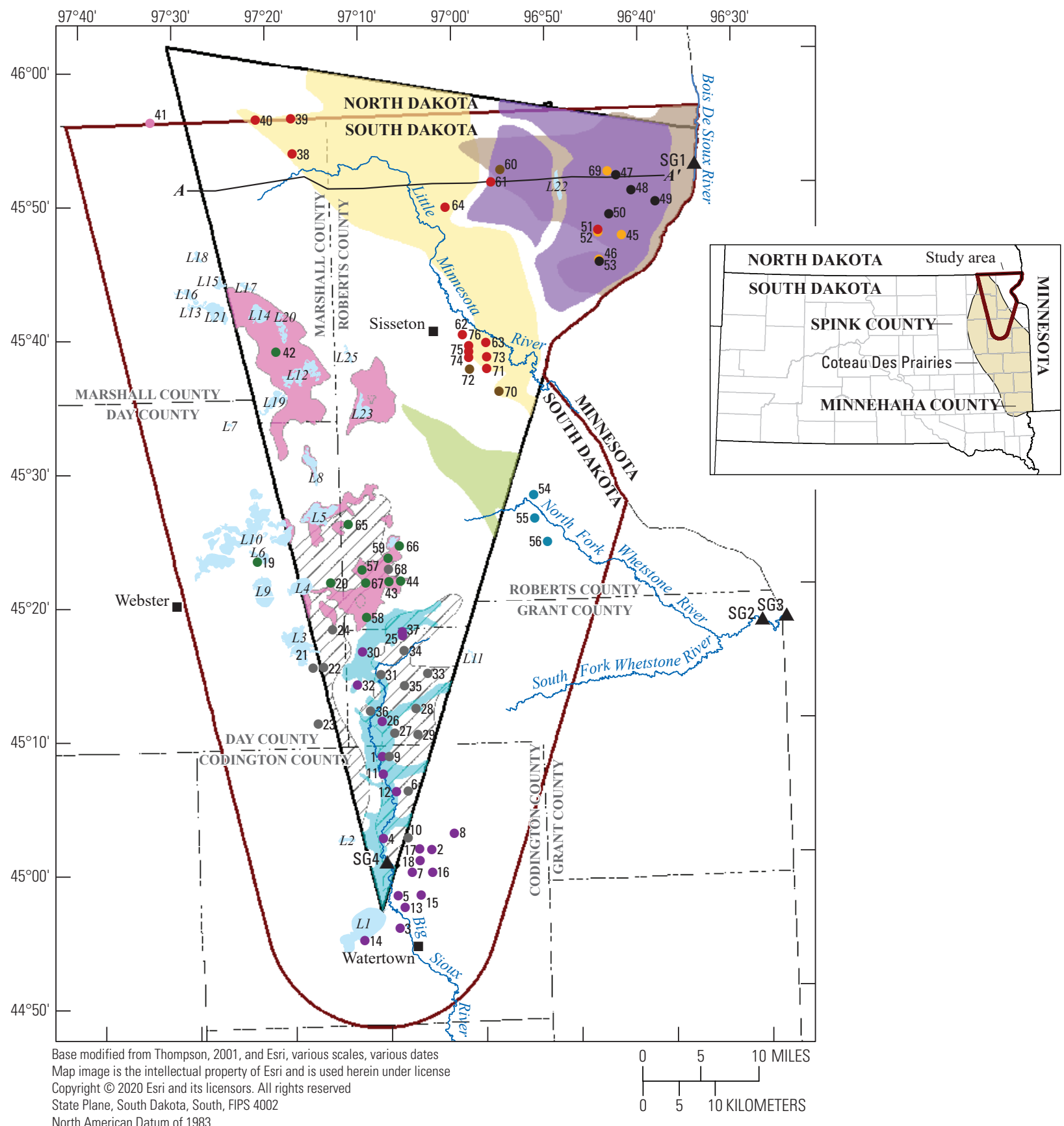

EXPLANATION

Select aquifers within the former Lake Traverse Reservation

North Big Sioux aquifer

Coteau Lakes aquifer system

Fairmount aquifer

Prairie Coteau outwash group

Revillo aquifer

Rosholt aquifer

Veblen aquifer system
Select lakes and identifier monitored by the South Dakota Department of Environment and Natural Resources (table 5)

$A-A^{\prime}$ Line of hydrogeologic section

Study area boundary

Former Lake Traverse Reservation boundary

SG1 U.S. Geological Survey streamgage and identifier (table 4)
South Dakota Department of Environment and Natural Resources observation wells in select aquifers (table 3)

37 - North Big Sioux aquifer

42 Coteau Lakes aquifer system

69 Fairmount aquifer

41. Middle James aquifer

68 Prairie Coteau outwash group

54 Revillo aquifer

47 Rosholt aquifer

40. Veblen aquifer

60 Pleistocene outwash deposit

Figure 1. Location of the study area, observation wells, lakes, streamgages, extents of select aquifers, and the historical 1867 boundary of the former Lake Traverse Reservation in northeastern South Dakota and southeastern North Dakota. 
Table 1. Summary of water use for calendar year 2015 for selected major categories for South Dakota counties in the study area.

[Water use data from Dieter and others (2018); Area of counties from U.S. Census Bureau (2018); GW, groundwater; Mgal/d, million gallons per day; SW, surface water]

\begin{tabular}{|c|c|c|c|c|c|c|c|c|c|c|}
\hline County & $\begin{array}{l}\text { Total for all } \\
\text { GW } \\
\text { (Mgal/d) }\end{array}$ & $\begin{array}{l}\text { GW public } \\
\text { supply } \\
\text { (Mgal/d) }\end{array}$ & $\begin{array}{l}\text { GW self- } \\
\text { supplied } \\
\text { domestic } \\
\text { (Mgal/d) }\end{array}$ & $\begin{array}{l}\text { GW live- } \\
\text { stock } \\
\text { (Mgal/d) }\end{array}$ & $\begin{array}{l}\text { Irrigation } \\
\text { GW } \\
\text { (Mgal/d) }\end{array}$ & $\begin{array}{l}\text { Irrigation SW } \\
\text { (Mgal/d) }\end{array}$ & $\begin{array}{c}\text { Irrigation } \\
\text { total } \\
\text { (Mgal/d) }\end{array}$ & $\begin{array}{c}\text { Irrigated area } 1 \\
\text { (thousands of } \\
\text { acres) }\end{array}$ & $\begin{array}{c}\text { Area of county } \\
\text { (thousands of } \\
\text { acres) }\end{array}$ & $\begin{array}{c}\text { Percent } \\
\text { irrigated }\end{array}$ \\
\hline Codington & 7.59 & 3.74 & 0.05 & 0.31 & 3.49 & 0.48 & 3.97 & 5.54 & 458.53 & 1.21 \\
\hline Day & 0.83 & 0.09 & 0.04 & 0.18 & 0.52 & 0.05 & 0.57 & 1.28 & 698.37 & 0.18 \\
\hline Grant & 4.34 & 0.63 & 0.05 & 0.4 & 3.26 & 0.1 & 3.36 & 5.9 & 440.26 & 1.34 \\
\hline Marshall & 0.75 & 0.21 & 0 & 0.47 & 0.07 & 0 & 0.07 & 0.36 & 566.58 & 0.06 \\
\hline Roberts & 2.91 & 0.58 & 0.05 & 0.45 & 1.83 & 0.13 & 1.96 & 4.15 & 726.45 & 0.57 \\
\hline Totals & 16.42 & 5.25 & 0.19 & 1.81 & 9.17 & 0.76 & 9.93 & 17.23 & $2,890.19$ & 0.60 \\
\hline Minnehaha² & 21.24 & 19.65 & 0 & 0.45 & 1.14 & 0.31 & 1.45 & 1.77 & 520.63 & 0.34 \\
\hline Spink $^{2}$ & 13.34 & 0.03 & 0.01 & 0.5 & 12.8 & 2.58 & 15.38 & 25.66 & 966.63 & 2.65 \\
\hline
\end{tabular}

1Irrigated area includes groundwater and surface-water sources.

2Provided as basis for comparison because Minnehaha and Spink Counties have the largest groundwater usage for public supply and irrigation in South Dakota, respectively. 
Table 2. Summary of selected characteristics for glacial aquifers and named glacial outwash groups within the study area.

[Data from Thompson (2001) for all aquifers except Pleistocene; NR, not reported]

\begin{tabular}{|c|c|c|c|c|c|c|c|}
\hline Name & $\begin{array}{l}\text { Areal extent } \\
\text { (square } \\
\text { miles) }\end{array}$ & $\begin{array}{c}\text { Maximum } \\
\text { thickness } \\
\text { (feet) }\end{array}$ & $\begin{array}{c}\text { Mean } \\
\text { thickness } \\
\text { (feet) }\end{array}$ & $\begin{array}{c}\text { Range in } \\
\text { depth below } \\
\text { land surface } \\
\text { to top of } \\
\text { aquifer or out- } \\
\text { wash material } \\
\text { (feet) }\end{array}$ & $\begin{array}{l}\text { Mean depth below } \\
\text { land surface to } \\
\text { top of aquifer or } \\
\text { outwash material } \\
\text { (feet) }\end{array}$ & $\begin{array}{c}\text { Artesian (A) or } \\
\text { water-table (WT) } \\
\text { (primarily) }\end{array}$ & $\begin{array}{l}\text { Suitability for } \\
\text { irrigation }\end{array}$ \\
\hline \multicolumn{8}{|c|}{ Glacial aquifers } \\
\hline Coteau Lakes system 1 & 102.9 & 65 & 25.4 & $0-45$ & 7.2 & WT, A & Yes \\
\hline North Big Sioux ${ }^{1}$ & 61.7 & 59 & 22.4 & $0-9$ & 3.1 & WT & Yes \\
\hline Altamont & 217.1 & 132 & 42.3 & $358-701$ & 464.7 & A & Yes \\
\hline Revillo $^{1}$ & 86.7 & 141 & 56.8 & $107-661$ & 252.3 & A & Yes \\
\hline Middle James 1 & 2.0 & 108 & 108 & NR & 677 & A & NR \\
\hline Veblen system ${ }^{1}$ & 277.2 & 191 & 47.1 & $11-179$ & 86.3 & WT, A & Yes \\
\hline Spiritwood & 19.4 & 98 & 49.0 & $1-180$ & 102.7 & A & Yes \\
\hline Hankinson & 15.2 & 10 & 10.0 & $22-27$ & 24.5 & A & Yes \\
\hline Rosholt $^{1}$ & 200.3 & 101 & 37.8 & $1-123$ & 37.6 & WT, A & Yes \\
\hline Milnor Channel & 54.8 & NR & NR & NR & NR & WT & NR \\
\hline Fairmount ${ }^{1}$ & 177.8 & 138 & 36.1 & $94-263$ & 186.0 & A & Yes \\
\hline \multicolumn{8}{|c|}{ Bedrock aquifer } \\
\hline Dakota & $1,738.0$ & NR & NR & $469-1,000$ & 705.8 & A & No \\
\hline \multicolumn{8}{|c|}{ Named, discontinuous outwash groups } \\
\hline Prairie Coteau ${ }^{1}$ & NR & 45 & 18.5 & $46-278$ & 132.4 & A & Yes \\
\hline Lonesome Lake & NR & 58 & 20.9 & 190-399 & 286.1 & A & Yes \\
\hline Marday & NR & 47 & 19.6 & $124-377$ & 216.7 & A & Yes \\
\hline Eden & NR & 40 & 18.8 & $256-508$ & 390.5 & A & Yes \\
\hline Roslyn & NR & 40 & 23.8 & $76-627$ & 363.9 & A & Yes \\
\hline Wilmot & NR & 54 & 17.9 & $2-78$ & 30.6 & WT & Yes \\
\hline \multicolumn{8}{|c|}{ Unnamed, discontinuous outwash groups } \\
\hline Pleistocene 1 & NR & NR & NR & NR & NR & NR & NR \\
\hline
\end{tabular}

${ }^{1}$ Indicates an aquifer for which water-level records are considered within this report.

1975), Leap (1972, 1988), and Hansen (1990). Descriptions of hydrogeology, physiography, and climate for Richland and Sargent Counties within North Dakota were provided by Paulson (1953), Powell (1956), Baker and Paulson (1967), and Armstrong (1982).

Glacial deposits within the study area include outwash deposits, lake deposits, and till (fig. 2). The glacial deposits are underlain by several Cretaceous-age sedimentary bedrock formations. The Cretaceous-age formations shown in figure 2 are underlain by the Cretaceous-age Dakota Formation, which is underlain by Precambrian-age crystalline rocks (Thompson, 2001).

A hydrogeologic section for line of section $A-A$ ' (fig. 1) is shown in figure 2, which is adapted from Thompson (2001), and provides an example of the complex hydrogeology within the study area. Test hole 128-49-21DDAD-R is about $8 \mathrm{mi}$ west of the eastern extent of the line of section and just east of Cottonwood Lake (North) (shown as lake L22 on fig. 1) in northeastern Roberts County. This test hole penetrates three unnamed outwash deposits in a vertical sequence beneath the Rosholt aquifer and above the Fairmount aquifer. About 5 or 6 mi east of this test hole, the Fairmont aquifer is discontinuous, which was interpreted from other proximal test holes not shown on figure 2 (Thompson, 2001). The Rosholt aquifer also is interpreted to be discontinuous where the Milnor Channel aquifer underlies Cottonwood Lake (North). About 5 or $6 \mathrm{mi}$ west of Cottonwood Lake (North), the outwash deposit containing the Rosholt aquifer is exposed at land surface and is penetrated by test hole 128-50-21CCCC-R. The glacial aquifers and outwash deposits receive recharge from precipitation 


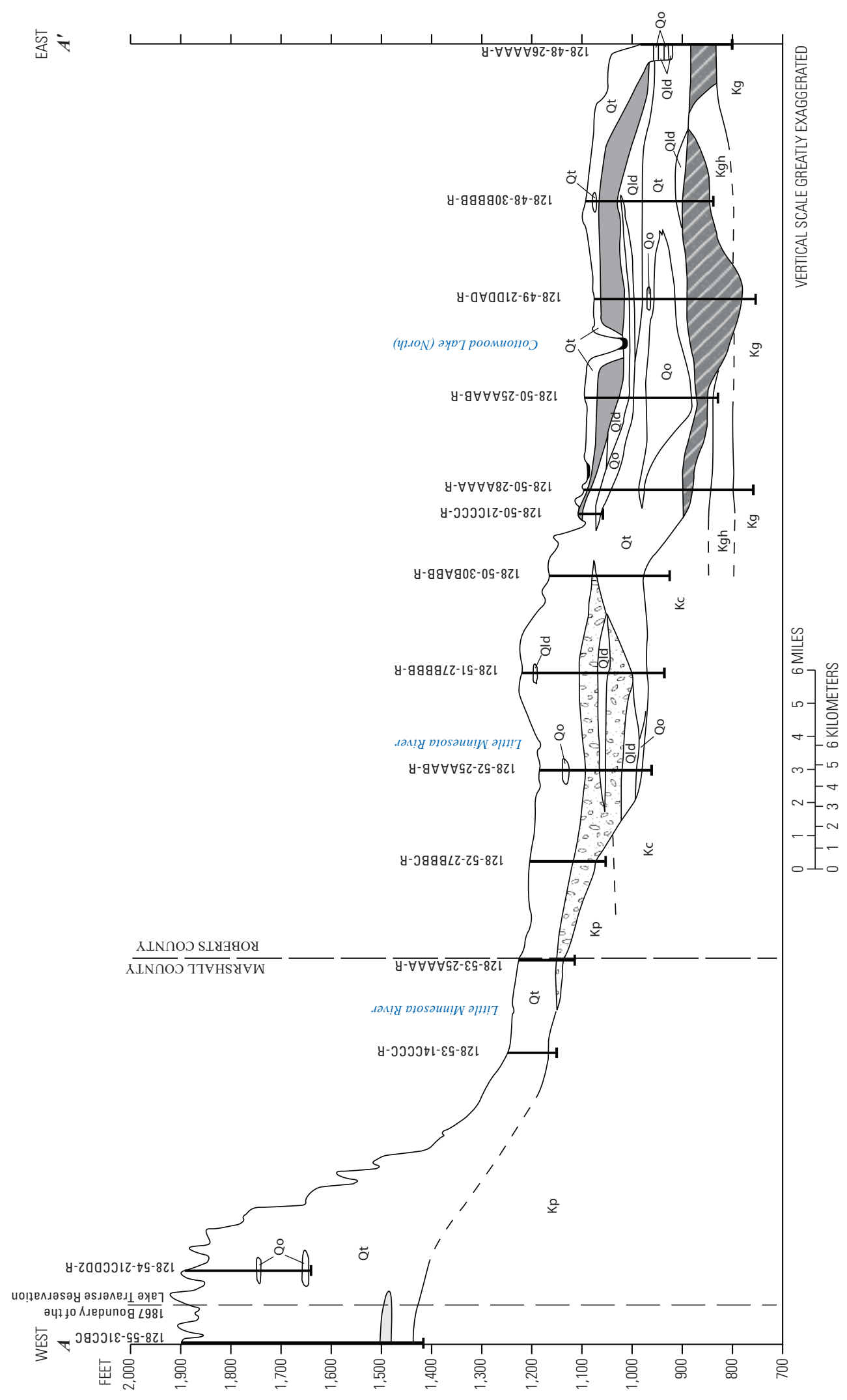

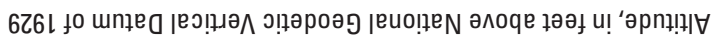

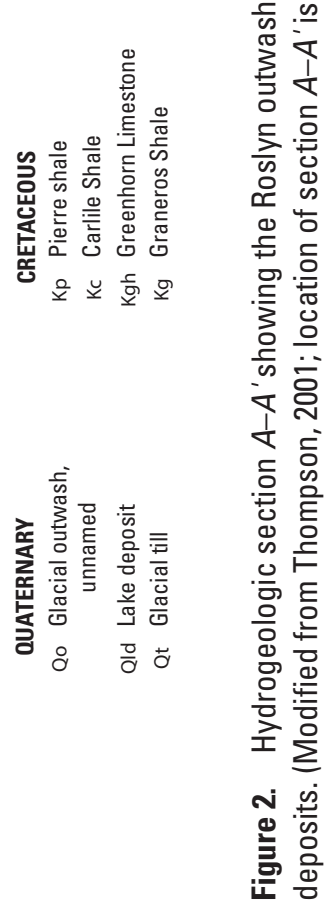


in outcrop areas such as this (Thompson, 2001), and watertable conditions typically occur in such areas. Farther east of test hole 128-50-21CCCC-R, the Rosholt aquifer is overlain by deposits of glacial till, which form an upper confining layer, and in combination with decreasing elevation for the Rosholt aquifer, provide a means for the artesian (confined) conditions indicated in table 2. Under artesian conditions, the water level in a well will rise above the elevation at which the aquifer is penetrated, as described in more detail by Erickson (1955).

Nine aquifers for which water-level records are considered within this report are identified in table 2. Areal extents of seven of these aquifers, as mapped by Thompson (2001) within the former reservation, are shown on figure 1; however, figure 1 does not show mapped extents for the Middle James and Pleistocene aquifers. Maps showing extents of glacial aquifers and outwash groups for areas in the 10-mi buffer area that are beyond the former reservation boundary and the rest of Roberts County were provided by Hansen (1990) for Codington and Grant Counties, Leap $(1972,1988)$ for Day County, and Koch $(1972,1975)$ for Marshall County. Development of maps showing the full extent of all of the glacial aquifers and outwash groups considered within the full study area would require joining of the maps from Thompson (2001) with those of the other aforementioned investigators. The effort required for joining of such maps is beyond the scope of this report; thus, readers are referred to the references cited for such information.

The glacial aquifers and outwash groups are underlain by a series of bedrock formations that were described by Thompson (2001). The Dakota aquifer is contained in the Dakota Formation (not shown in fig. 2) and has artesian conditions throughout the study area (Thompson, 2001). Winter (1994) provided water-level data for five wells completed in the Dakota aquifer in the study area; however, none of those wells have been monitored as part of SDDENR's observation well network. Thus, those data are not considered within this report.

Much of the study area is poorly drained, with numerous wetlands and lakes, many of which are within "closed basins" that typically do not contribute to streamflow. Thompson (2001) identified interactions between surface water and water levels in the glacial aquifers and outwash groups within the study area. Many of the numerous lakes in the study area are known to have connections with groundwater. The North Big Sioux aquifer is hydraulically connected to the Big Sioux River, which drains the southern part of the study area, and the Veblen aquifer is hydraulically connected to the Little Minnesota River, which drains the eastern flank of the Coteau des Prairies (Thompson, 2001).

Climate conditions and groundwater withdrawals are widely recognized as two primary factors that affect water levels for any given aquifer. Climate conditions can affect groundwater levels primarily through changes in recharge conditions. Groundwater discharge from some aquifers can provide base flow to streams or rivers. Thus, groundwater levels in some aquifers can decline naturally during prolonged periods of below-mean recharge associated with prolonged drought conditions. Groundwater levels can rise somewhat quickly in response to large episodic recharge associated with periods of above-mean precipitation; however, declines in response to prolonged below-mean precipitation typically are slower. Declining groundwater levels may be further affected by increased groundwater withdrawals during dry periods. Lack of detailed records regarding actual versus permitted groundwater withdrawals further complicates quantification of the complex interactions among recharge, groundwater withdrawals, groundwater discharge, and other factors. Thus, this study precluded quantitative analyses of factors driving groundwater response, and only qualitative analyses are performed.

\section{Data Sources and Analytical Methods}

Analyses primarily involved (1) temporal trends for measured water levels in observation wells and for estimated precipitation at each observation well, (2) qualitative consideration of interactions between groundwater and surface water, and (3) qualitative consideration of effects of groundwater withdrawals on groundwater levels. All datasets considered are compiled by water year (WY), which is a 12-month period from October 1 through September 30 and is designated by the calendar year in which it ends. Within this report, all references to years involving water-related data are for WYs, unless specifically noted as calendar years.

\section{Data Sources}

Five primary datasets are considered within this report, including three datasets obtained from SDDENR (2018) that include records of water levels in observation wells, water levels in lakes, and data regarding licensed groundwater withdrawals in the study area. Climate data are from the Parameter-elevation Regressions on Independent Slopes Model (PRISM; Daly and others, 1994, 2002, 2008). Streamflow data from the USGS (U.S. Geological Survey, 2019) also are considered.

\section{Climate Data}

Climate data were estimated using total precipitation, minimum air temperature $\left(T_{\min }\right)$, and maximum air temperature $\left(T_{\max }\right)$ outputs from PRISM (Daly and others, 1994, 2002, 2008). PRISM interpolates monthly total precipitation, monthly means of daily $T_{\min }$, and monthly means of daily $T_{\max }$ from weather stations to a 2.5 arc-minute grid for the conterminous United States. Monthly PRISM data for total precipitation, $T_{\min }$, and $T_{\max }$ were aggregated to obtain datasets of annual total precipitation and annual means of $T_{\min }$ and $T_{\max }$ for the study area and a surrounding buffer area. These gridded data were used to display spatial distributions of trends 
in climate data. The time-series data for annual precipitation were used to further evaluate precipitation trends for the study area.

Monthly PRISM data were summed to annual total precipitation for individual well locations for comparisons to water-level records for all observations wells that were considered. Before summing, monthly precipitation for each well was estimated by inverse weighting by distance to cell centers of the four closest cell centers of the 2.5 arc-minute grid cell for each well location. PRISM data generally become progressively less reliable before about 1960 (Gibson and others, 2002) because of decreasing density of source data. This lack of reliability was not considered an issue, however, because precipitation data before 1960 were used only minimally for comparisons with water-level records. PRISM data for total precipitation dating back to 1895 , which is the oldest extent of available PRISM data (Gibson and others, 2002), were used to provide a perspective on long-term precipitation trends for the study area.

\section{Water-Level Records}

The primary dataset includes publicly available records of measured water levels for 76 observation wells (table 3 ) monitored by SDDENR (2018) that are within $5 \mathrm{mi}$ of the historical reservation boundary (fig. 1). The 5-mi buffer is used to fill data gaps along the historical boundary and to evaluate potential effects of withdrawals near the former reservation. Consideration of observation wells in Minnesota and North Dakota was beyond the scope of the study. All wells are assigned map numbers in table 3 that identify the wells on figure 1. Most of the wells follow a naming convention that identifies the county, calendar year it was drilled, and a "sequential" letter. For example, well CD-76D (map number S9, fig. 1) is the fourth of four wells drilled in Codington County during calendar year 1976. Seven wells in Roberts County (map numbers 70-76) are named using only the county and sequential identifiers.

The oldest water-level records date back to August 28, 1957 (table 3), for two wells in Codington County (CD56A and CD-57A) and one well in Grant County (GT-57A). Only seven wells have records that start before calendar year 1976 - five wells in Codington County and one each in Grant and Marshall Counties. The water-level records consist of sporadic (approximately monthly) measurements of water levels made primarily during or near months of typical irrigation demand, with minimal measurements during nonirrigation months. Water-level records are biased towards more frequent measurements during irrigation periods; thus, trends in water levels were analyzed as three annual datasets (minimum, median, and maximum water level) for each observation well (hereinafter referred to as "water-level parameters").

\section{Surface-Water Data}

Thompson (2001) described interactions between groundwater and surface water within the study area. Thus, streamflow data and water-level data for selected lakes were considered for qualitative comparison with water-level records for observation wells within the study area. Data for four streamgages (table 4, fig. 1) operated by the USGS (U.S. Geological Survey, 2019) are considered. The Bois de Sioux River flows north and is a tributary to the Red River of the North (not shown on fig. 1). The Whetstone and Little Minnesota Rivers are tributaries to the Minnesota River (not shown on fig. 1). Additional streamgages have been operated by the USGS within the study area; however, only streamgages shown on figure 1 are considered for analyses.

Site information for 25 selected lakes within the study area (fig. 1) where SDDENR has collected water-level records is provided in table 5 (SDDENR, 2019b). Several additional lakes that are measured by SDDENR are excluded from table 5 because (1) in some cases periods of record are less than 10 years and (2) records for some lakes are similar to records for one or more of the selected lakes and do not provide additional useful information.

\section{Licensed Groundwater Withdrawals}

Licensed groundwater withdrawals primarily include withdrawals for irrigation and municipal use and exclude minor withdrawals for uses such as domestic and stockwater supplies, as described further within this section. The USGS National Water Information System database (U.S. Geological Survey, 2019) lists a total of 4,309 groundwater withdrawal wells in the five counties within the study area, as of October 29, 2019. However, only licensed groundwater withdrawals are used in this report for accumulating estimates of withdrawals within specified radii of each observation well.

Locations of licensed groundwater withdrawals in the study area are shown in figures $3 A$ and $3 B$. Circles with radii of 0.5 and $1.0 \mathrm{mi}$ are plotted around each observation well to provide a perspective on the number of licensed groundwater withdrawals within those radii of each observation well.

The State of South Dakota has jurisdiction for issuing water-right permits and licenses for non-Tribal lands within the former Lake Traverse Reservation. Locations of permitted/licensed groundwater withdrawals and records of (maximum allowable) groundwater usage were obtained from the SDDENR (2017) for consideration in qualitative assessments of potential effects of withdrawals on water-level records for observation wells. The issuance of a water right by SDDENR is a two-step process that essentially consists of initial issuance of a water-right permit that is followed by issuance of a water-right license after a required inspection is performed (SDDENR, 2019a). A 5-year period is allowed for development of water-use infrastructure before the inspection is required. In most cases, inspections are performed and licenses are issued before the 5-year period has elapsed; however, 
Table 3. Selected site information for observation wells within the study area.

[M, month; DD, day; YYYY, year; NGVD 29, National Geodetic Vertical Datum of 1929]

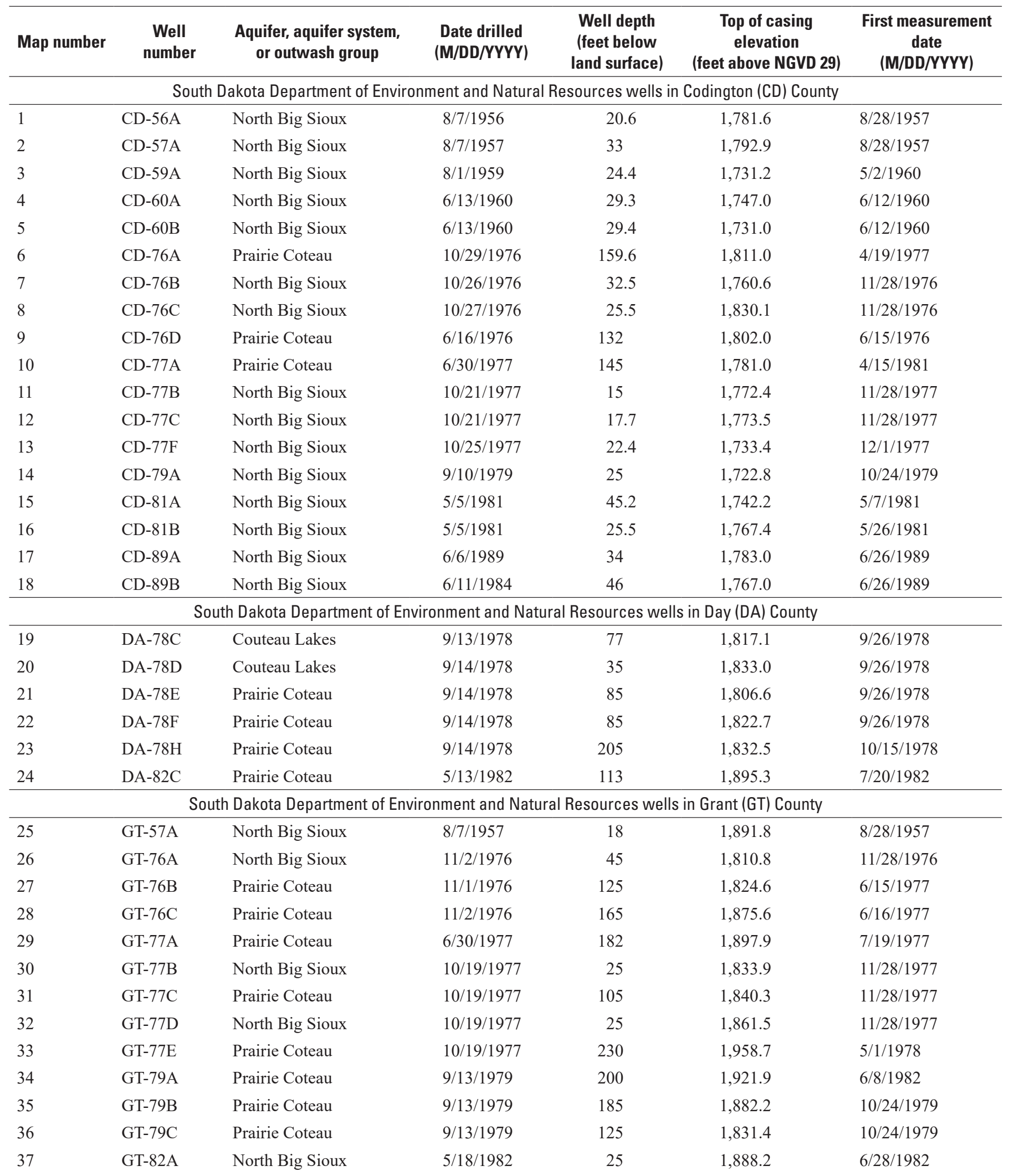


Table 3. Selected site information for observation wells within the study area._-Continued

[M, month; DD, day; YYYY, year; NGVD 29, National Geodetic Vertical Datum of 1929]

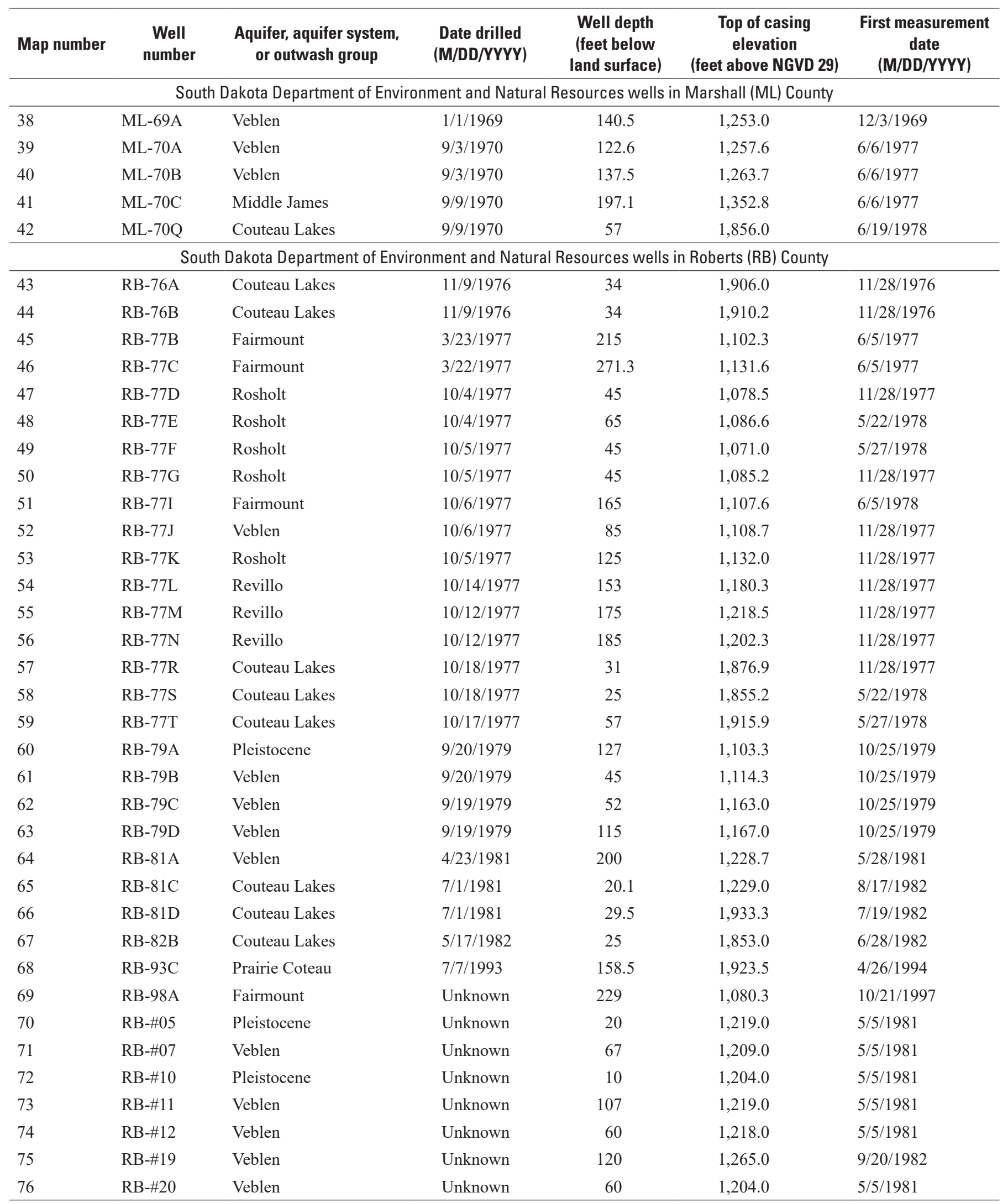


Table 4. Site information for selected streamgages within the study area.

\begin{tabular}{|c|c|c|c|c|c|}
\hline $\begin{array}{c}\text { Map } \\
\text { number }\end{array}$ & $\begin{array}{l}\text { Streamgage } \\
\text { number }\end{array}$ & Station name & Short name & $\begin{array}{l}\text { Drainage area } \\
\text { (square miles) }\end{array}$ & $\begin{array}{c}\text { Period of } \\
\text { record used } \\
\text { (water years) }\end{array}$ \\
\hline SG1 & 05050000 & $\begin{array}{l}\text { Bois De Sioux River near White Rock, } \\
\text { South Dakota }\end{array}$ & Bois De Sioux River & 1,160 & $1942-2017$ \\
\hline SG2 & 05291000 & $\begin{array}{l}\text { Whetstone River near Big Stone City, } \\
\text { South Dakota }\end{array}$ & Whetstone River & 389 & $1931-2017$ \\
\hline SG4 & 06479438 & Big Sioux River near Watertown, South Dakota & Big Sioux River & 1,007 & $1973-2017$ \\
\hline
\end{tabular}

Table 5. Site information for selected lakes with water-level records within the study area.

[Last measured, date of last measurement through water year 2017; M, month; DD, day; YYYY, year;]

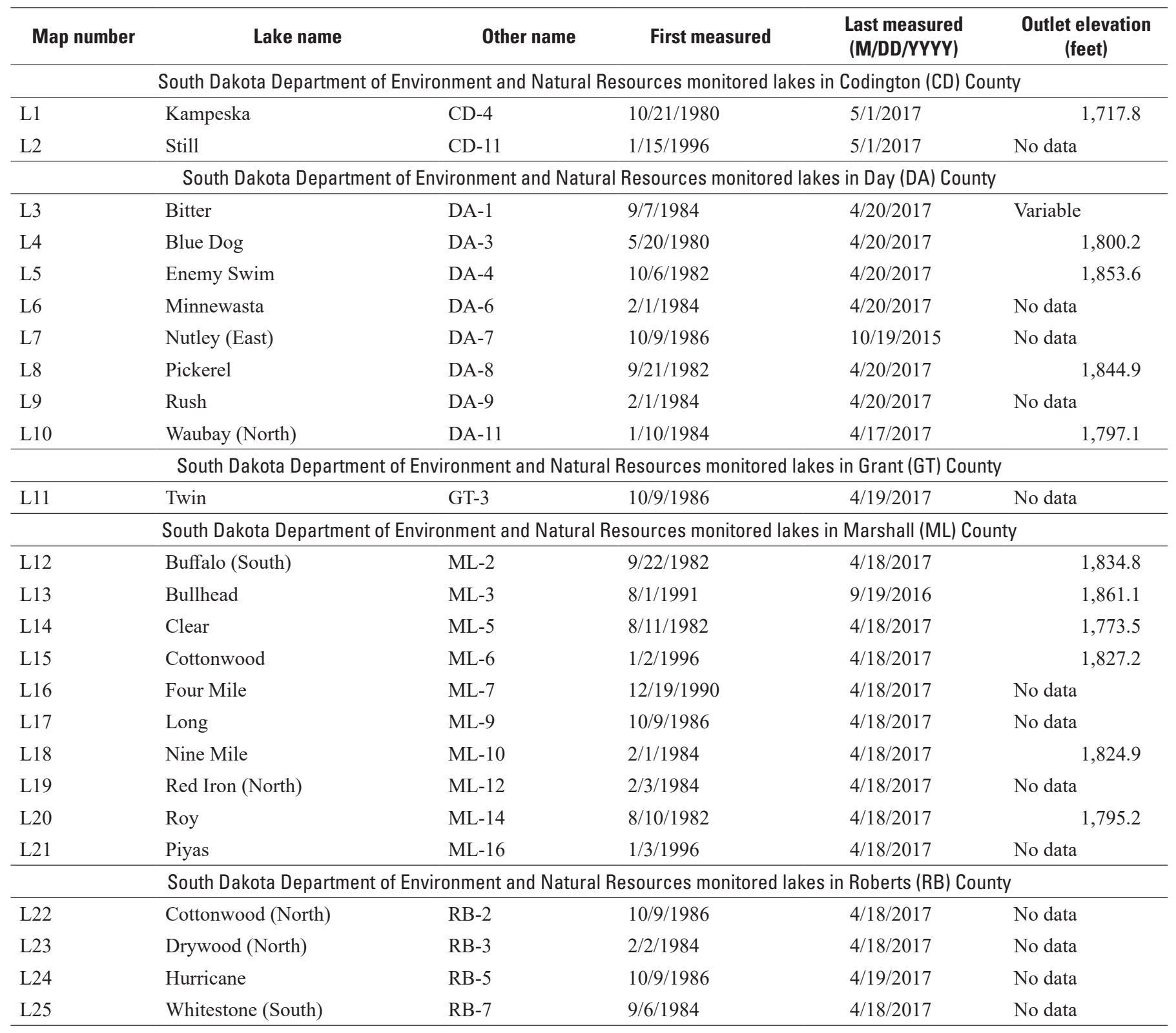




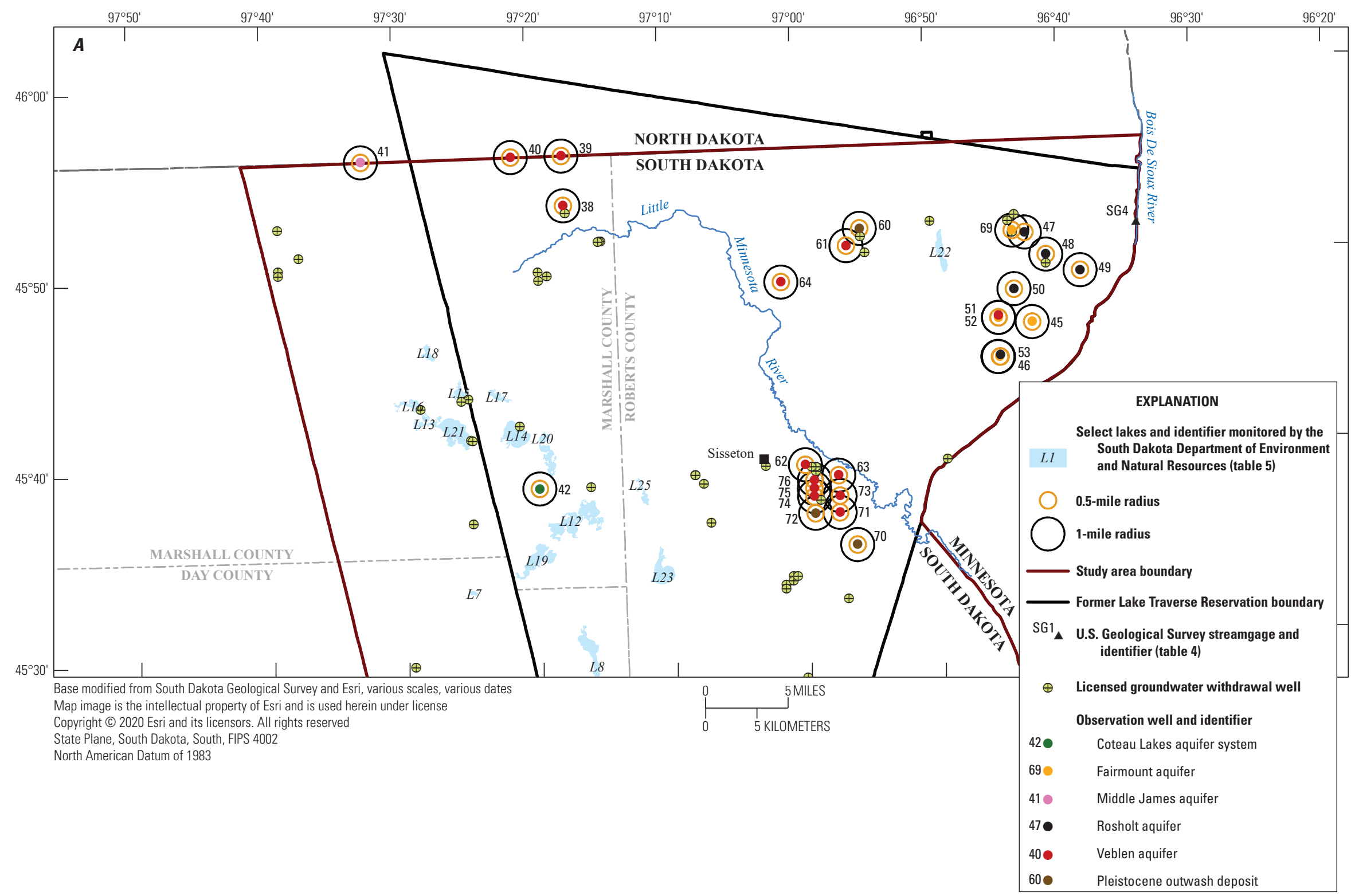

Figure 3. Locations of licensed groundwater withdrawals within the study area, relative to locations of observations wells. $A$, map of licensed groundwater withdrawals location relative to observation well locations in the northern one-half of the study area; and $B$, map of licensed groundwater withdrawals location relative to observation well locations in the southern one-half of the study area. 


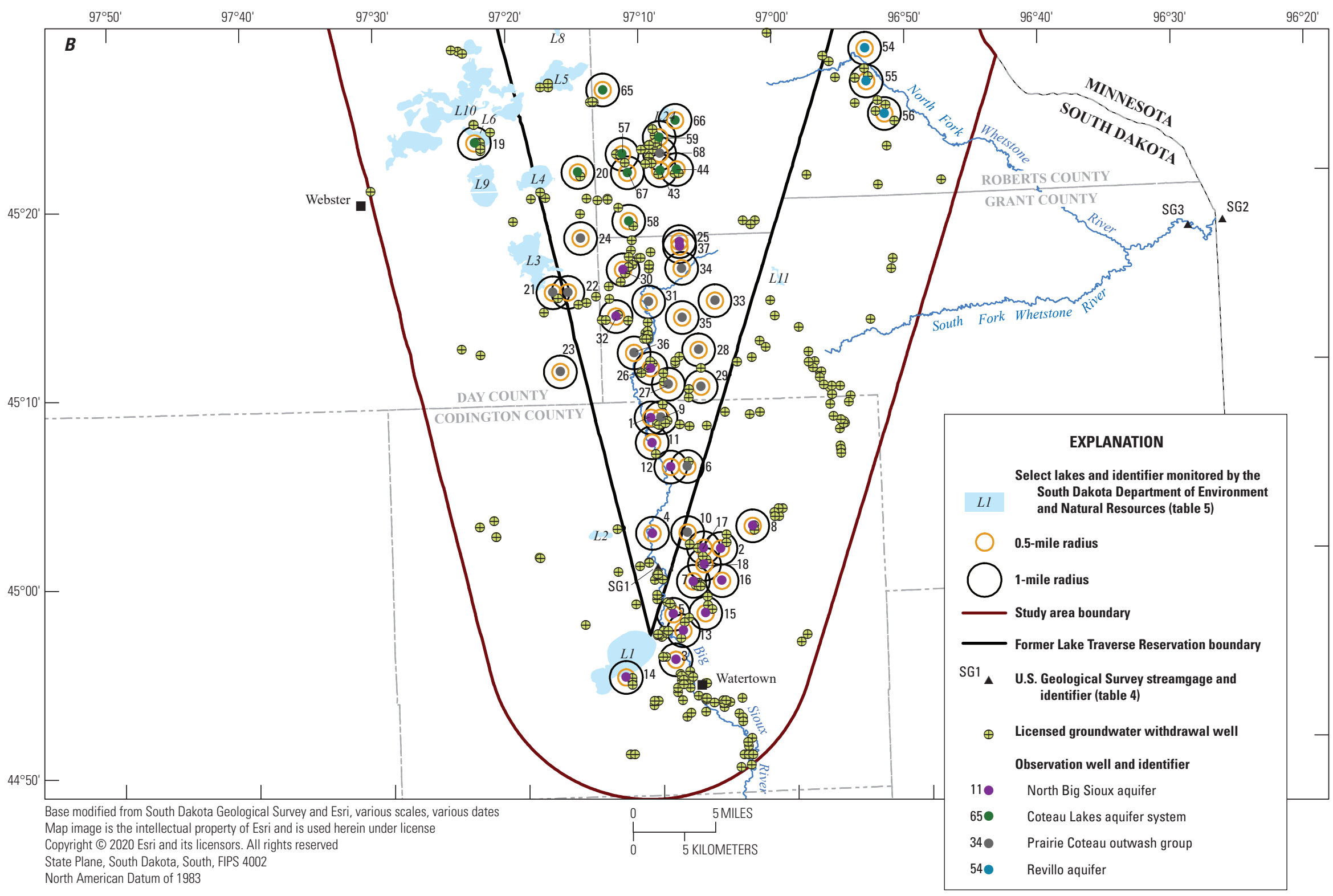

Figure 3. Locations of licensed groundwater withdrawals within the study area, relative to locations of observations wells. $A$, map of licensed groundwater withdrawals location relative to observation well locations in the northern one-half of the study area; and $B$, map of licensed groundwater withdrawals location relative to observation well locations in the southern one-half of the study area.-Continued 
inspections and licensing can extend beyond 5 years. Licensed (maximum allowable) withdrawal rates are not necessarily identical to the original permitted rates and usually are somewhat smaller than permitted rates. Thus, licensed withdrawal rates were used for estimation of groundwater withdrawal rates, except for cases where licensing has not yet been completed, which required use of permitted withdrawal rates.

True "starting" dates for permitted or licensed withdrawals cannot be precisely determined from the SDDENR database (SDDENR, 2017) for several reasons. A "priority" date for each permitted water right is established by the filing date of each water-right application, and in some cases, withdrawals may begin within a year or less of the priority date. In other cases, withdrawals may not begin for 5 years or more and only slightly in advance of the licensing date. Another factor is that some of the licensed groundwater withdrawals in the study area substantially predate South Dakota's current permitting/ licensing system, and in some cases priority dates precede license dates by one or more decades. Thus, priority dates were used as the starting dates for estimation of groundwater withdrawals.

Licensed groundwater withdrawals for "center-pivot" irrigation systems are a primary source of groundwater demand in the study area. Pumping rates of about 1 to 2 cubic feet per second $(\mathrm{ft} 3 / \mathrm{s})$ or about 450 to 900 gallons per minute are typical (SDDENR, 2017) for center-pivot systems that typically irrigate a circular area within a "quarter-section" of land (onefourth of a square mile). In some cases, a center-pivot system may be served by a single well; however, in other cases, two or more wells may be needed to produce sufficient water. The SDDENR database (SDDENR, 2017) provides individual well locations when multiple wells are used to serve a single irrigation system; however, details regarding production rates for individual wells are not necessarily readily available. Thus, for cases of multiple well locations associated with a single water-right permit or license, an assumption of equal production from each well is used for the qualitative assessments that are performed.

The State of South Dakota does not require permitting/ licensing for small-scale groundwater withdrawals of less than 25 gallons per minute $(0.06 \mathrm{ft} 3 / \mathrm{s})$, depending on criteria (SDDENR, 2019a). No attempt was made to account for groundwater withdrawals not reported by SDDENR. No attempt was made to account for withdrawals in nearby parts of Minnesota or North Dakota, because this was beyond the scope of the study. An arbitrary maximum distance of $5 \mathrm{mi}$ is used for accumulation of estimated groundwater withdrawal rates.

A summary of estimated licensed groundwater withdrawals over time throughout the study area, including (1) minimal withdrawals before 1957, (2) slow increases in withdrawals during about 1957-75, (3) and much larger increases since about 1975, is provided in figure 4. By the end of WY 2017, cumulative groundwater withdrawals throughout the study area totaled about $370 \mathrm{ft} 3 / \mathrm{s}$.

Actual cumulative withdrawal rates likely are much smaller than shown in figure 4 because (1) the estimated withdrawals are based on maximum permitted/licensed withdrawal rates, which typically are approached only during particularly dry years; and (2) the irrigation season typically includes less than 6 months of each year. A more realistic perspective on actual water use is provided by table 1 , which is based on reported water use for 2015 (Dieter and others, 2018). Groundwater withdrawals during 2015 totaled 16.42 million gallons per day (11,403 gallons per minute) for the five counties within the study area.

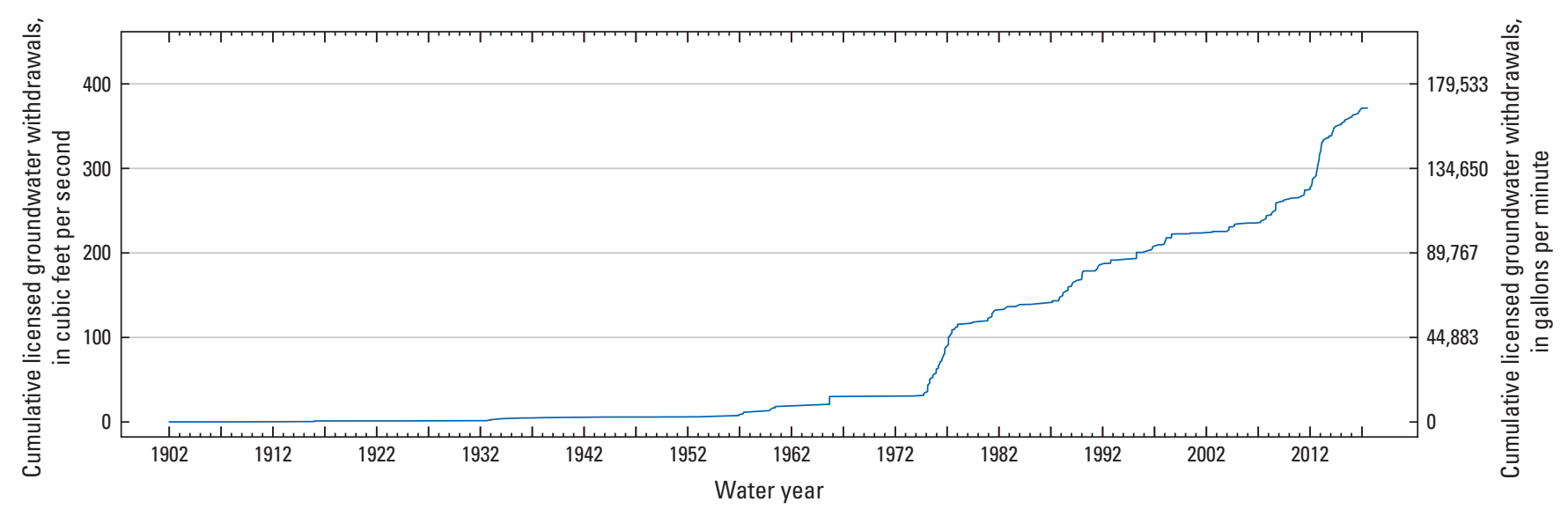

Figure 4. Summary of groundwater withdrawals over time for the study area. 


\section{Statistical and Analytical Methods}

Various statistical methods are used for analysis of temporal trends for climatic and hydrologic data. For all trend analyses in this report, the independent $(x)$ variable is time (annual or seasonal), and the dependent $(y)$ variable is a climate or hydrologic variable (precipitation, temperature, or water levels in wells). Seasons, where applicable, are defined throughout this analysis as October-December, January-

March, April-June, and July-September.

Some of the statistical analyses involve determination of trend magnitude, or the mean change over time for an analysis period. Trend magnitudes are computed using the Sen's slope estimator (Sen, 1968) using the modifiedmk R package developed by Patakamuri (2018). Sen's slope, also referred to as the Kendall-Theil robust line (Helsel and others, 2020), is a nonparametric estimator of trend magnitude per time interval (slope) for a univariate time series when the time interval is constant (equally spaced).

Two statistical analyses were used to test for statistical significance of temporal trends. The nonparametric MannKendall test (Kendall, 1938; Helsel and others, 2020) is the primary method used to determine statistical significance of trends. The null hypothesis for this method is " $\left(\mathrm{H}_{0}\right)$ is rejected if the value of $\mathrm{S}$ is statistically significantly different from zero" (Helsel and others, 2020, p. 332), where $\mathrm{H}_{0}$ is no change and $\mathrm{S}$ is Kendall's tau $(\tau)$ of $y$ versus the time variable; alternatively, a monotonic trend is assumed. Trends are considered statistically significant for probability values ( $p$-values) less than or equal to 0.10 (90-percent confidence level) for the null hypothesis that Kendall's $\tau$ equals zero. Kendall's tau measures the degree of correspondence between two variables, with $\tau$ ranging from -1 to 1 . If $\tau=-1$, the data have a perfect negative correlation or downward trend. If $\tau=1$, the data have a perfect positive correlation or upward trend. If $\tau=0$, there is no correlation or trend.

An issue for trend analysis of hydroclimatic datasets has been potential effects of serial correlation within timeseries data (Cohn and Lins, 2005). There are two types of serial correlation, short-term persistence (STP) and long-term persistence. STP is when past measurements influence the subsequent measurements in a short timeframe and long-term persistence is influence of past measurements on subsequent measurements in a long timeframe or infinite timeframe (Koutsoyiannis and Montanari, 2007). A standard MannKendall test is appropriate only for time-series data that are identically distributed, independent, and have no short- or long-term persistence (Wilks, 2011). If these assumptions are violated, for example when series are autocorrelated, the standard Mann-Kendall $p$-values can decrease, causing Type I errors. Type I errors are the false acceptance of a trend as statistically significant when, in fact, no trend exists. Longterm persistence typically can be observed only in periods of record more than 50-100 years (Hodgkins and Dudley, 2011). However, long-term persistence was not considered a concern because the oldest well records date back to calendar years
1957-60 for only 6 of 76 wells (table 3), with all other records starting in calendar year 1969 or later. In contrast, STP was of potential concern, because the precipitation and groundwater measurements are consecutive time series.

To determine which Mann-Kendall test to use for statistical significance and magnitudes of temporal trends, applicable data were tested for statistically significant STP using the Auto Correlation Function (Venables and Ripley, 2002) from the R stats package (R Core Team, 2017).

The standard version of the nonparametric Mann-Kendall test (Kendall, 1938; Helsel and others, 2020) was used to determine statistical significance of trends for datasets that showed little or no STP. Various methods can be used to modify the Mann-Kendall test to minimize effects of STP (Hamed and Rao, 1998; Hamed, 2008; Önöz and Bayazit, 2012; Bayazit, 2015); however, such methods typically make the Mann-Kendall test less sensitive to trends. For datasets with substantial STP, the Modified Mann-Kendall Test from the modifiedmk R package (Patakamuri, 2018) was used. The function uses the Hamed and Rao (1998) variance correction approach, wherein a trend-free time series is constructed by calculating Sen's slope and Auto Correlation coefficients to calculate a new $p$-value.

A locally estimated scatterplot smoothing (LOESS) curve with a span of 0.8 was used to aid in the visualization of trends for some datasets. The 0.8 span was selected because it provided a generalized visual representation of the trend. The LOESS curve is a multivariate and single variate smoothing procedure (Cleveland and Devlin, 1988; Cleveland and others, 1992) that can be applied to a time series. The Local Polynomial Regression Fitting function from the R stats package (R Core Team, 2017) was used to calculate the LOESS curve values for single variates to be plotted.

Plots and trends over time for groundwater levels and for annual precipitation for the 76 observation wells are presented in appendix figures 1.1 through 1.76. Measured lake levels for selected lakes within the study area and data regarding groundwater withdrawals, if present, within specified radii of each observation well are also included in figures 1.1 through 1.76; however, trends in lake levels and withdrawals over time are not analyzed.

An example of the graphics for data and analyses that are presented in the figures in the appendix is provided in figure 5, which is identical to figure 1.37. This example is for well DA-78C (map number 19 in table 3, fig. 1), which is completed in the in the Coteau Lakes aquifer system. The individual measurements of water levels for well DA-78C that date back to September 26, 1978 (table 3), and estimated annual total precipitation from PRISM data (inverse weighted for the four closest 2.5 arc-minute grid cells) beginning in WY 1956 are shown in figure $5 A$. The 1956-2017 precipitation period is shown on figures 1.1 through 1.76 so that a common time scale can be used for the $\mathrm{x}$-axis for all figures. This period starts about 2 years before the earliest available waterlevel measurements (table 3). A 2-year offset was arbitrarily selected because scrutiny of water-level and precipitation data 

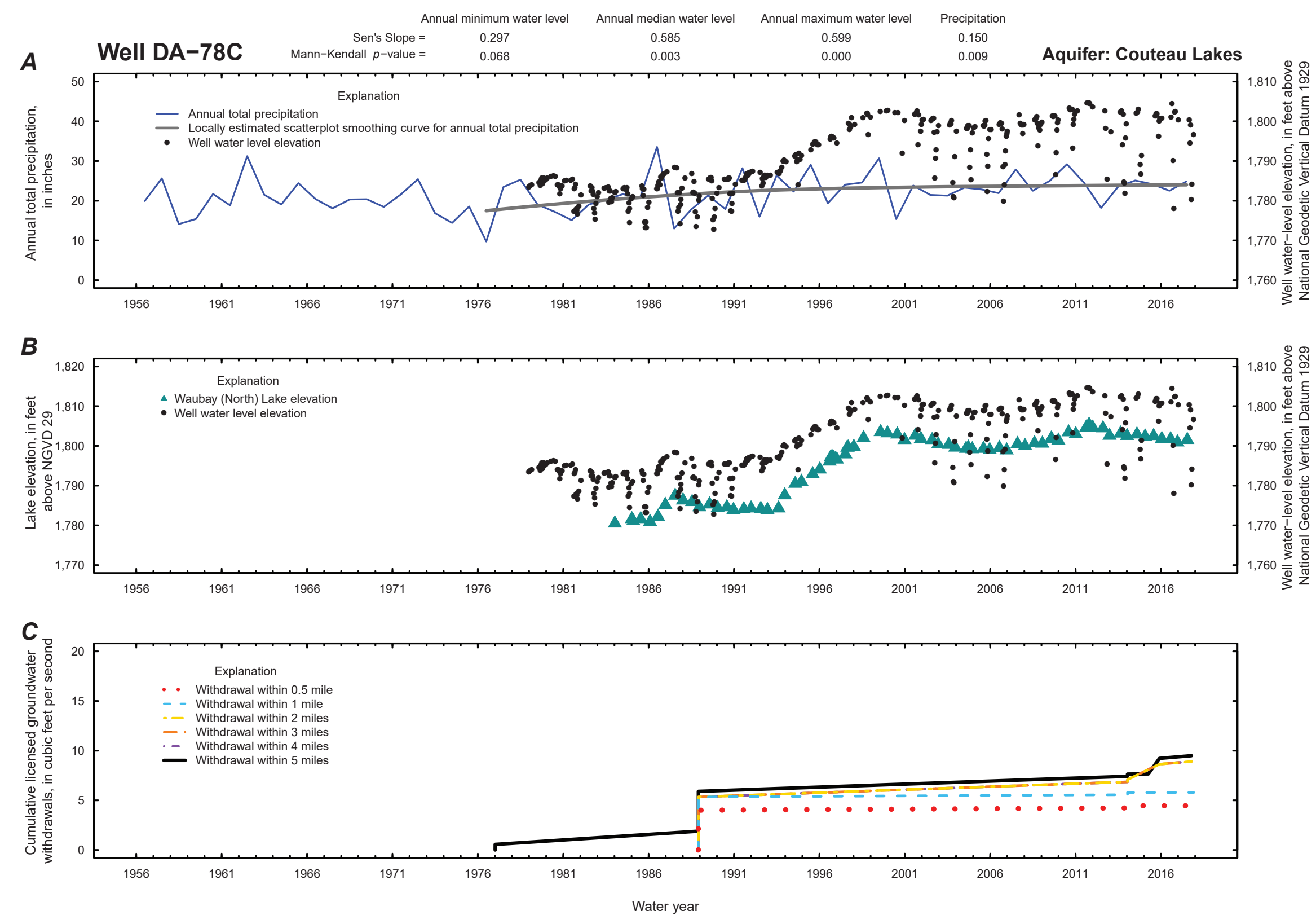

Figure 5. Example analysis that includes three graphs showing trends in measured groundwater levels and annual precipitation totals, lake levels for a selected lake, and proximal groundwater withdrawals for observation well DA-78C (map number 19, fig. 1). $A$, groundwater levels and annual total precipitation; $B$, groundwater levels and lake levels; and $C$, sum of groundwater withdrawals within specified radii of observation well. 
indicated that responses of groundwater levels for some of the observation wells lagged major changes in precipitation patterns by as much as 2 years.

Results of time-trend analyses are shown at the top of figure $5 \mathrm{~A}$ for three annual water-level parameters (minimum, median, and maximum) for WYs 1977-2017 and for the annual totals of precipitation for WYs 1976-2017, which reflects the 2-year offset that is used for precipitation data. A LOESS curve that is fit to the time series for the total annual precipitation starting in WY 1976 is also included in figure $5 \mathrm{~A}$. The LOESS curve aids in visualizing the statistically significant upward trend for annual precipitation (Mann-Kendall $p$-value $=0.009$, Sen's slope $=0.150$ ), which means that annual precipitation has increased by 0.15 inch per year, or about 6.3 inches (in.) between WYs 1976 and 2017. Results indicate statistically significant upward trends for all three annual water-level parameters. The same individual measurements of water levels in figure $5 A$ are also shown in figure $5 B$, along with measured water levels for a selected lake (Waubay [North] Lake). Licensed groundwater withdrawals, by year, within six specified radii $(0.5,1,2,3,4$, and $5 \mathrm{mi})$ of observation well DA-78C are shown in figure $5 C$. If a specified radius is not plotted, then there were no records of licensed groundwater withdrawals within that specified radius. As described in the "Licensed Groundwater Withdrawals" section, the licensed groundwater withdrawals primarily represent maximum allowable withdrawal rates for wells permitted or licensed by SDDENR. In instances where there are no known licensed groundwater withdrawals within $5.0 \mathrm{mi}$ of a specified observation well, graph $\mathrm{C}$ is not included on the appendix 1 figures.

\section{Characterization of Factors Affecting Groundwater Levels}

Factors affecting fluctuations in groundwater levels for selected observation wells in the study area are characterized in this section. Climate conditions are a primary driver of trends in groundwater levels; thus, trends in climate data are analyzed first. Effects of streamflow and lake levels on groundwater levels also are characterized before the analysis of groundwater trends because of the interactions between surface water and groundwater. It should be noted that trends analyzed in this report are applicable only for the specific periods of record that are considered and should not be construed as forecasts of future conditions.

\section{Climate Trends}

The spatial distribution of statistically significant trends for annual PRISM climate data (total precipitation, $T_{m i n}$, and $T_{\max }$ from aggregated PRISM data) for WYs 1956-2017 is shown in figure 6 , which reflects the offset of about 2 years before the earliest available water-level measurements (table 3). The trends in annual climate data provide a qualitative perspective regarding potential effects on groundwater levels, because (1) increased precipitation has potential to increase recharge rates and (2) increased temperature has potential to increase evapotranspiration, which could cause decreased recharge and increased irrigation demand. Statistically significant upward trends are shown for annual precipitation (fig. $6 A$ ) and annual $T_{\min }$ (fig. $6 B$ ) for most of the study area and the surrounding buffer area. Statistically significant downward trends in $T_{\max }$ are shown for only a few 2.5 arc-minute grid cells within the study area (fig. 6C); however, the sparsity of the spatial coverage reduces confidence that these are true trends, relative to the near completeness of the spatial coverage in upward trends for $T_{\text {min }}$ (fig. $6 B$ ).

The spatial distribution of statistically significant trends in seasonal climate data, which are generally similar to the annual trends, but with substantial differences in the spatial density of the trends, are shown in figures 7-10. These figures show that the generally upward trends in annual precipitation (fig. 6A) are driven primarily by upward trends for October-December (fig. 7A), January-March (fig. $8 A$ ), and July-September (fig. 10A), all of which have at least partial spatial coverage in upward trends. The generally upward trends for annual $T_{\min }$ (fig. $6 B$ ) are driven to at least some extent by upward trends for all four seasons. Seasonal trends for $T_{\max }$ are generally nonsignificant, with the exception of July-September (fig. 10C), which has downward trends for much of the study area.

Trend magnitudes were not calculated for the spatial climate data derived from PRISM (total precipitation, $T_{\text {min }}$, and $T_{\max }$ ), because of the large number of grid cells involved. STP was tested for the time series for the annual climate data shown in figure 6 and was not detected for any of the three datasets (fig. 2.1). Thus, statistical significance was determined using the standard Mann-Kendall test. The seasonal climate data were not tested for STP because statistically significant STP was not detected for any of the three annual datasets that were tested.

Additional information regarding long-term precipitation patterns for the study area is provided in figure 11. Annual total precipitation from PRISM for WYs 1956-2017 is shown in figure $11 \mathrm{~A}$. The long-term mean for this period is $22.58 \mathrm{in}$. The annual departure from the mean is shown in figure $11 B$ and has essentially the same pattern as figure $11 \mathrm{~A}$. The cumulative annual departure from the mean is shown in figure $11 C$ and clearly shows multiyear periods of above- or below-mean precipitation. Years since 1990 constitute an extended period of generally above-mean precipitation, as indicated by the generally upward slope during 1990-2017. Years before 1983 were generally below mean and 1983-89 were generally near mean.

Annual total precipitation data for the study area similar to that of figure 11, but for 1896-2017, which is the earliest availability of data from PRISM, are shown in figure 12. The 1896-2017 mean is 22.20 in., which is 0.38 in. less than the mean for 1956-2017. Above-mean precipitation since 

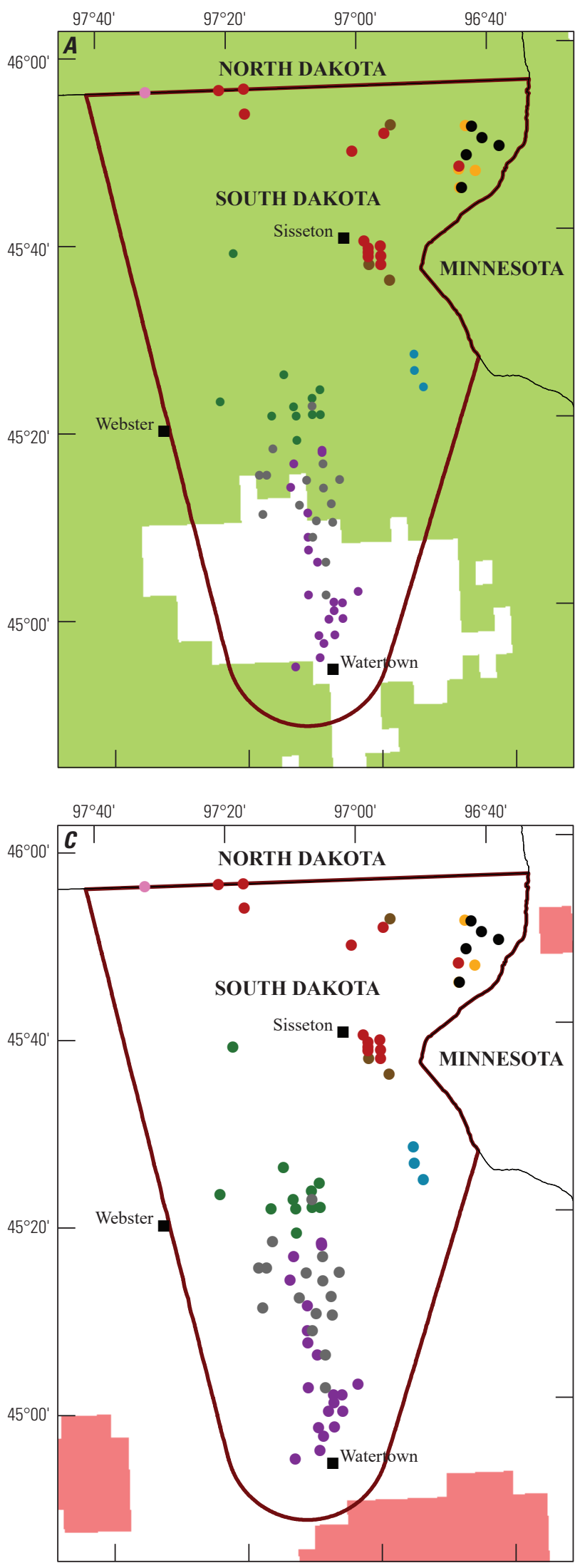

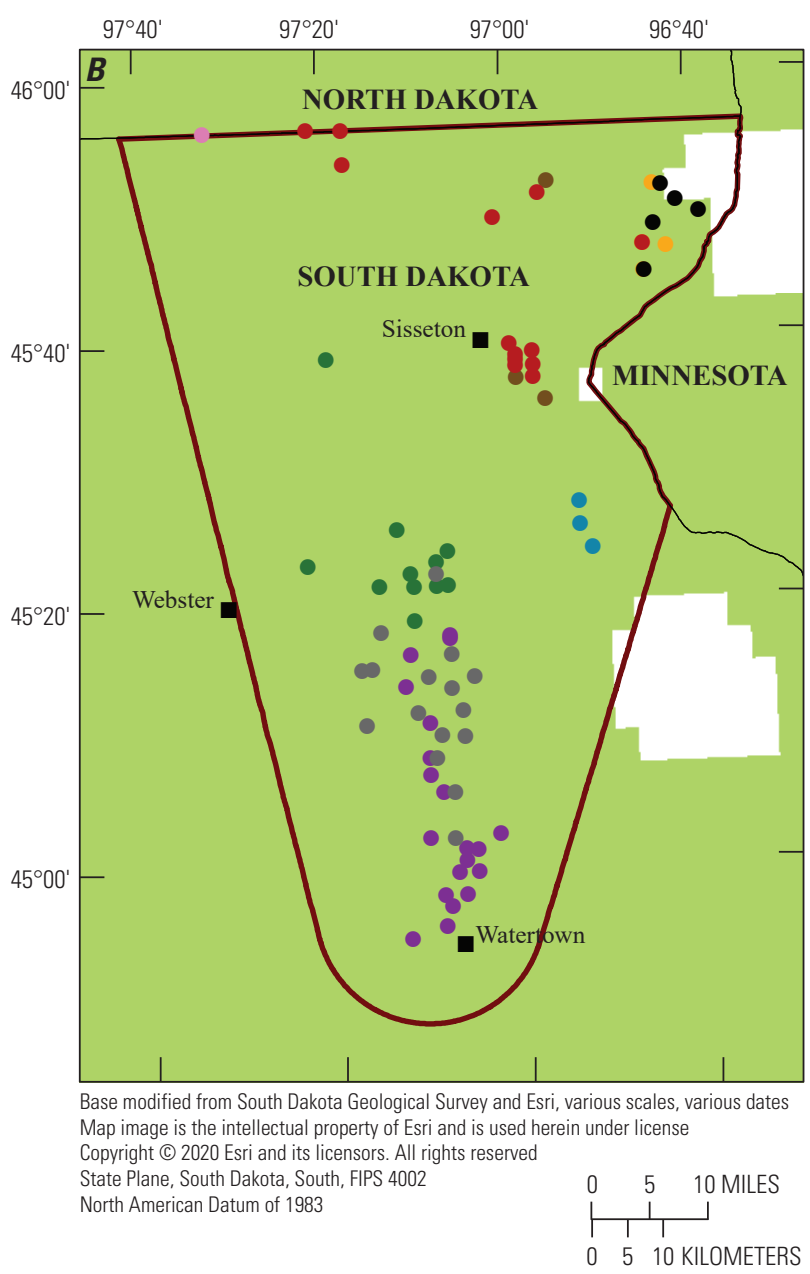

\section{EXPLANATION}

Statistically significant downward trend

No statistically significant trend

Statistically significant upward trend

Study area boundary

Observation well

- North Big Sioux aquifer

- Coteau Lakes aquifer system

- Fairmount aquifer

- Middle James aquifer

- Revillo aquifer

- Rosholt aquifer

- Veblen aquifer

- $\quad$ Prairie Coteau outwash group

- $\quad$ Pleistocene outwash deposit

Figure 6. Spatial distribution of statistically significant trends in annual climate data within the study area, water years $1956-2017$. $A$, total precipitation; $B$, monthly means of daily minimum air temperature; and $C$, monthly means of daily maximum air temperature. 

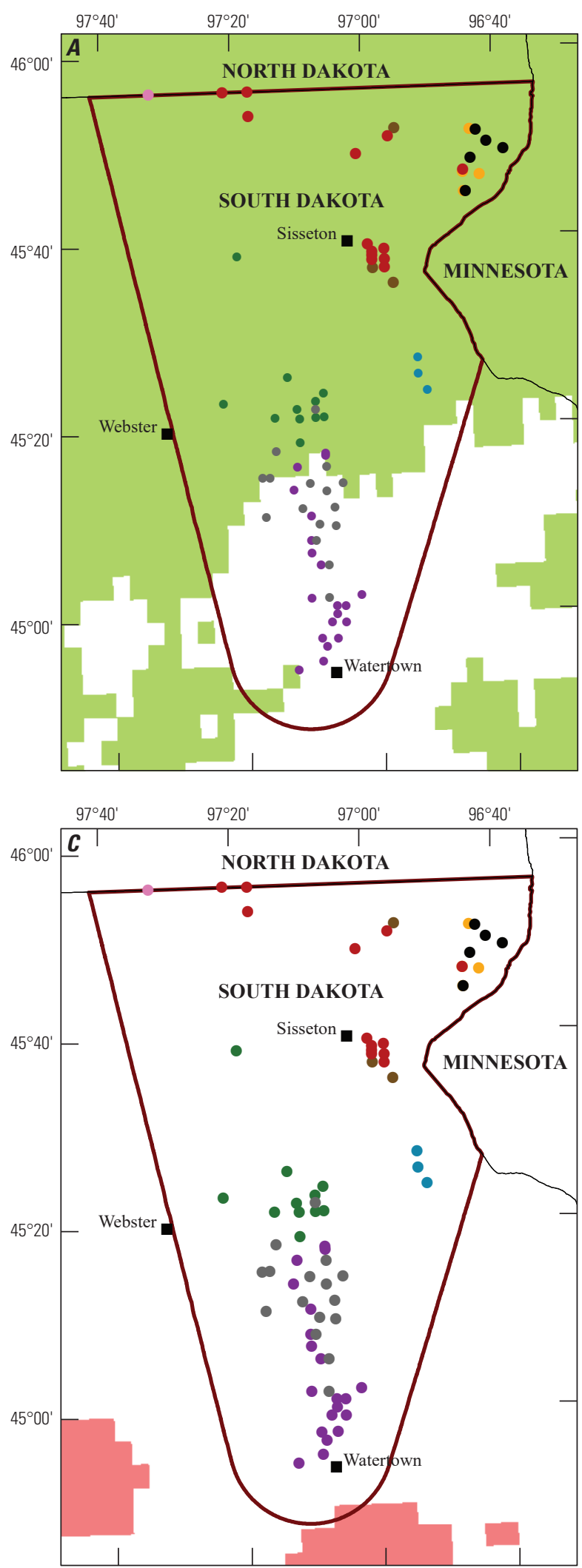

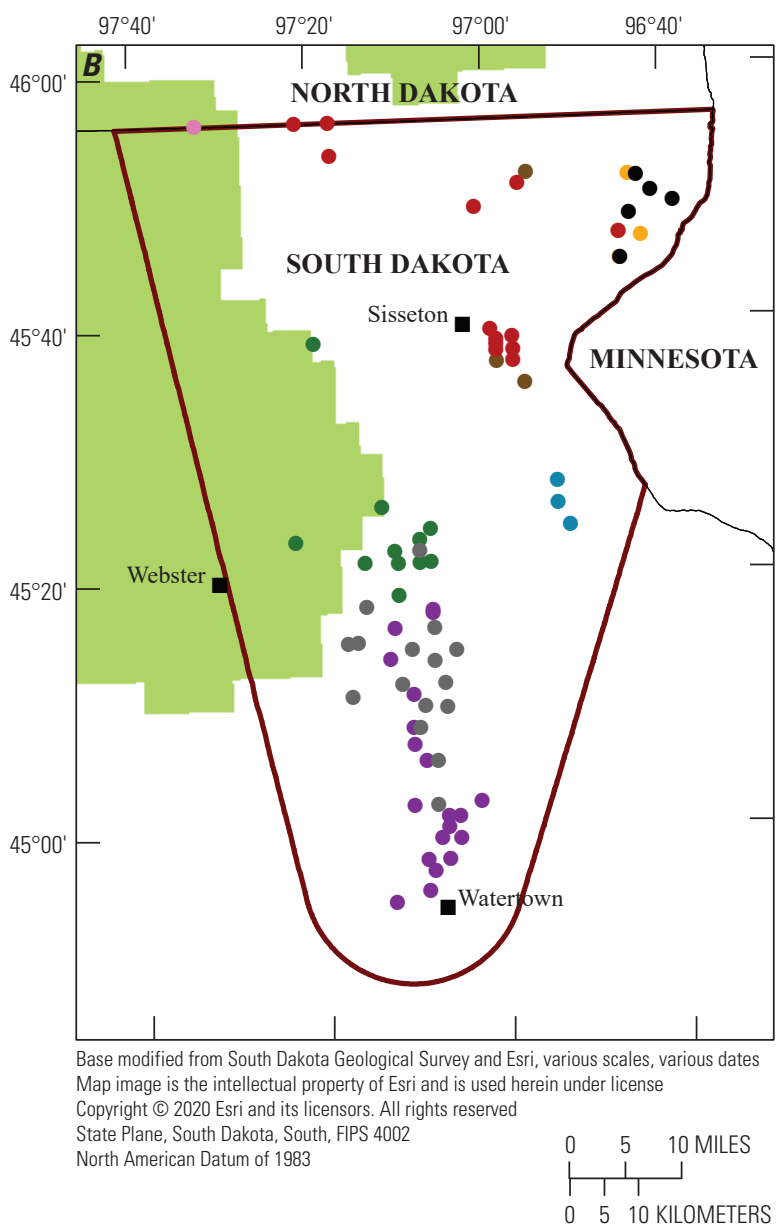

\section{EXPLANATION}

Statistically significant downward trend

No statistically significant trend

Statistically significant upward trend

Study area boundary

Observation well

- North Big Sioux aquifer

- Coteau Lakes aquifer system

- Fairmount aquifer

- Middle James aquifer

- Revillo aquifer

- Rosholt aquifer

- Veblen aquifer

- Prairie Coteau outwash group

- Pleistocene outwash deposit

Figure 7. Spatial distribution of statistically significant trends in seasonal (0ctober-December) climate data within the study area, water years 1956-2017. $A$, total precipitation; $B$, monthly means of daily minimum air temperature; and $C$, monthly means of daily maximum air temperature. 

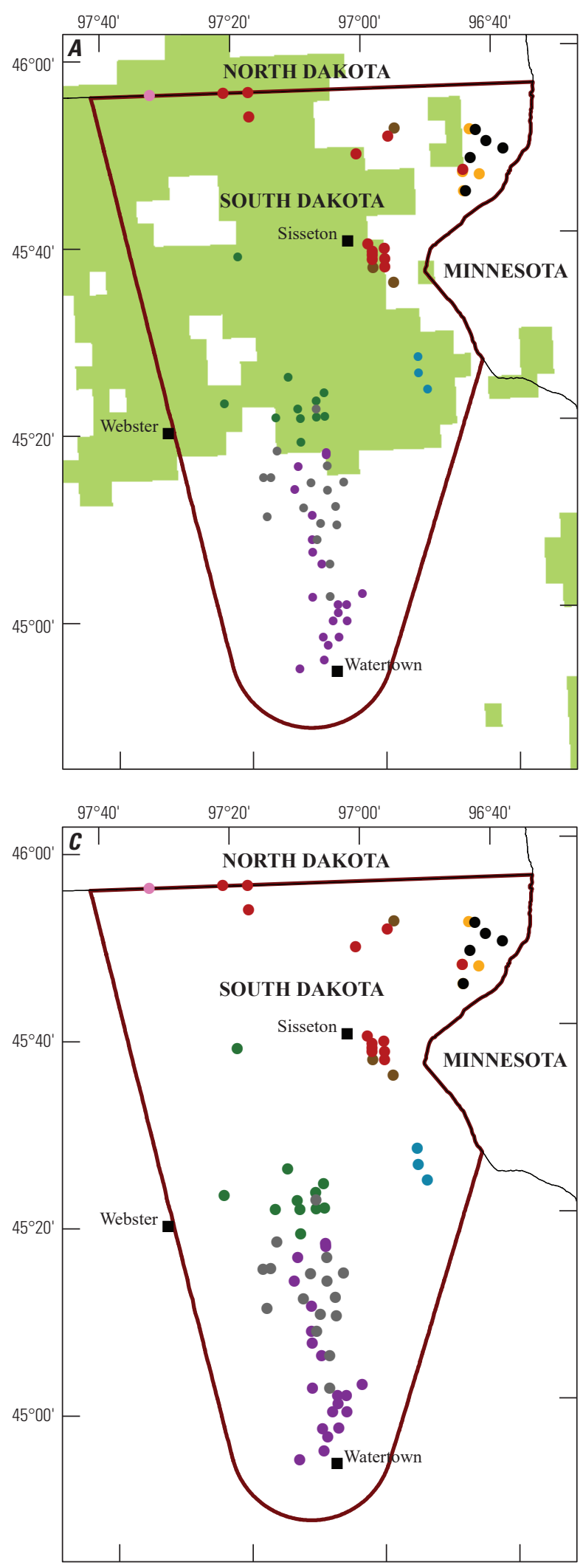

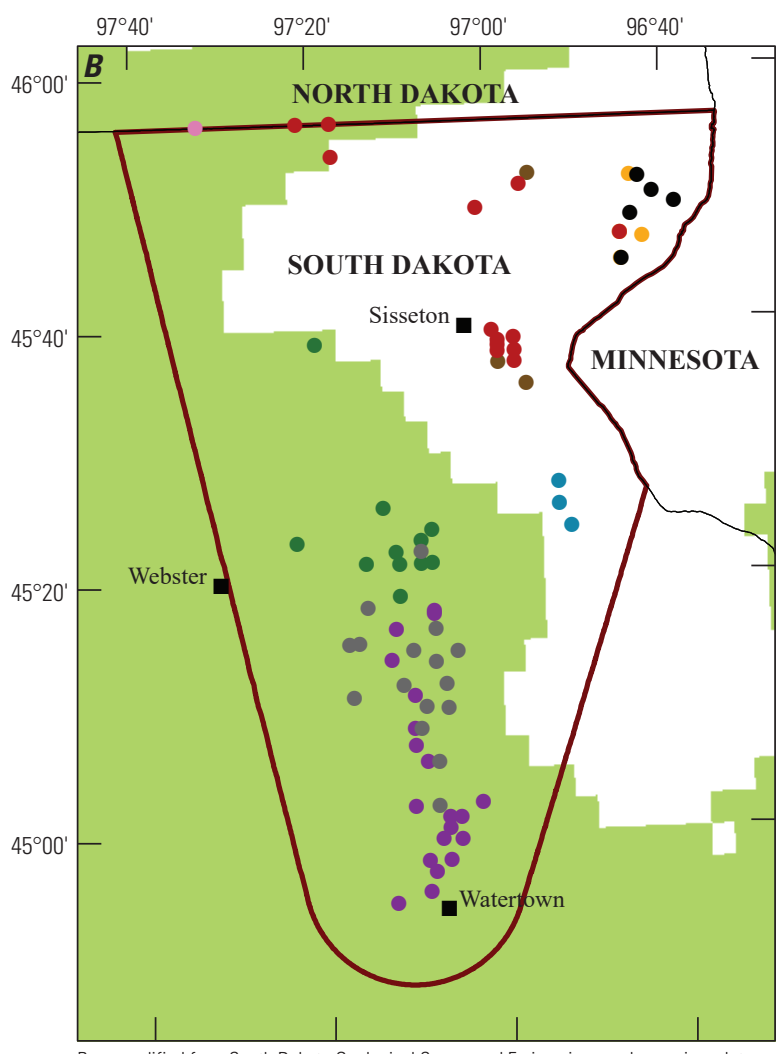

Base modified from South Dakota Geological Survey and Esri, various scales, various dates Map image is the intellectual property of Esri and is used herein under license Copyright (@) 2020 Esri and its licensors. All rights reserved

State Plane, South Dakota, South, FIPS 4002

$0 \quad 5 \quad 10$ MILES

North American Datum of 1983

$0 \quad 5 \quad 10$ KILOMETERS

\section{EXPLANATION}

\section{tatistically significant downward trend}

No statistically significant trend

Statistically significant upward trend

Study area boundary

Observation well

- North Big Sioux aquifer

- $\quad$ Coteau Lakes aquifer system

- Fairmount aquifer

- Middle James aquifer

- Revillo aquifer

- Rosholt aquifer

- Veblen aquifer

- Prairie Coteau outwash group

- Pleistocene outwash deposit

Figure 8. Spatial distribution of statistically significant trends in seasonal (January-March) climate data within the study area, water years 1956-2017. A, total precipitation; $B$, monthly means of daily minimum air temperature; and $C$, monthly means of daily maximum air temperature. 

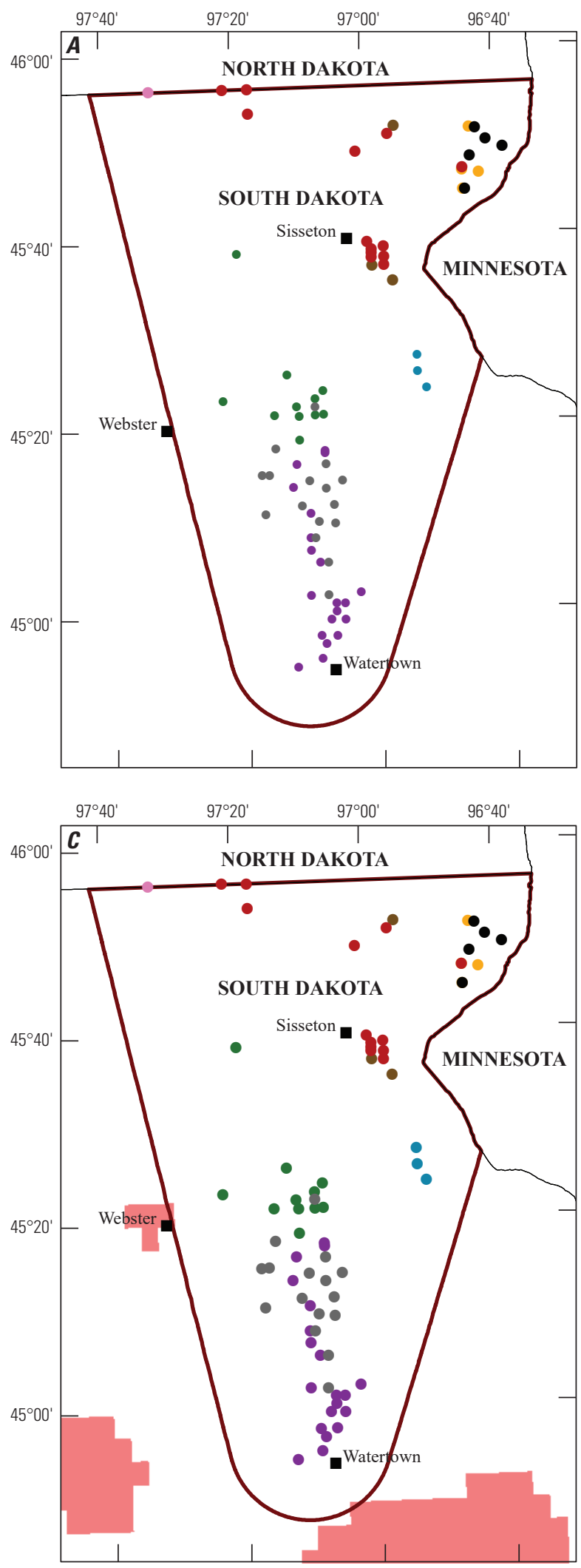

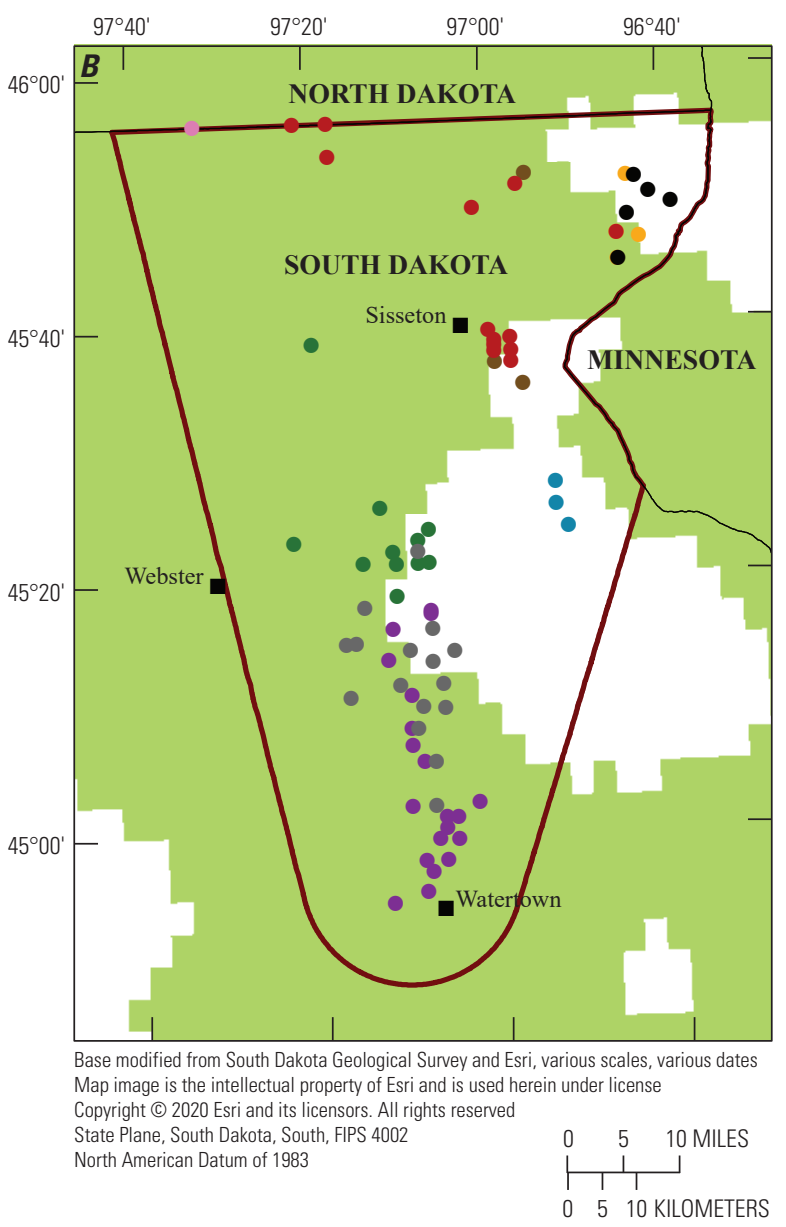

\section{EXPLANATION}

Statistically significant downward trend

No statistically significant trend

Statistically significant upward trend

Study area boundary

Observation well

- North Big Sioux aquifer

- Coteau Lakes aquifer system

- Fairmount aquifer

Middle James aquifer

- Revillo aquifer

- Rosholt aquifer

- Veblen aquifer

- $\quad$ Prairie Coteau outwash group

- Pleistocene outwash deposit

Figure 9. Spatial distribution of statistically significant trends in seasonal (April-June) climate data within the study area, water years 1956-2017. $A$, total precipitation; $B$, monthly means of daily minimum air temperature; and $C$, monthly means of daily maximum air temperature. 

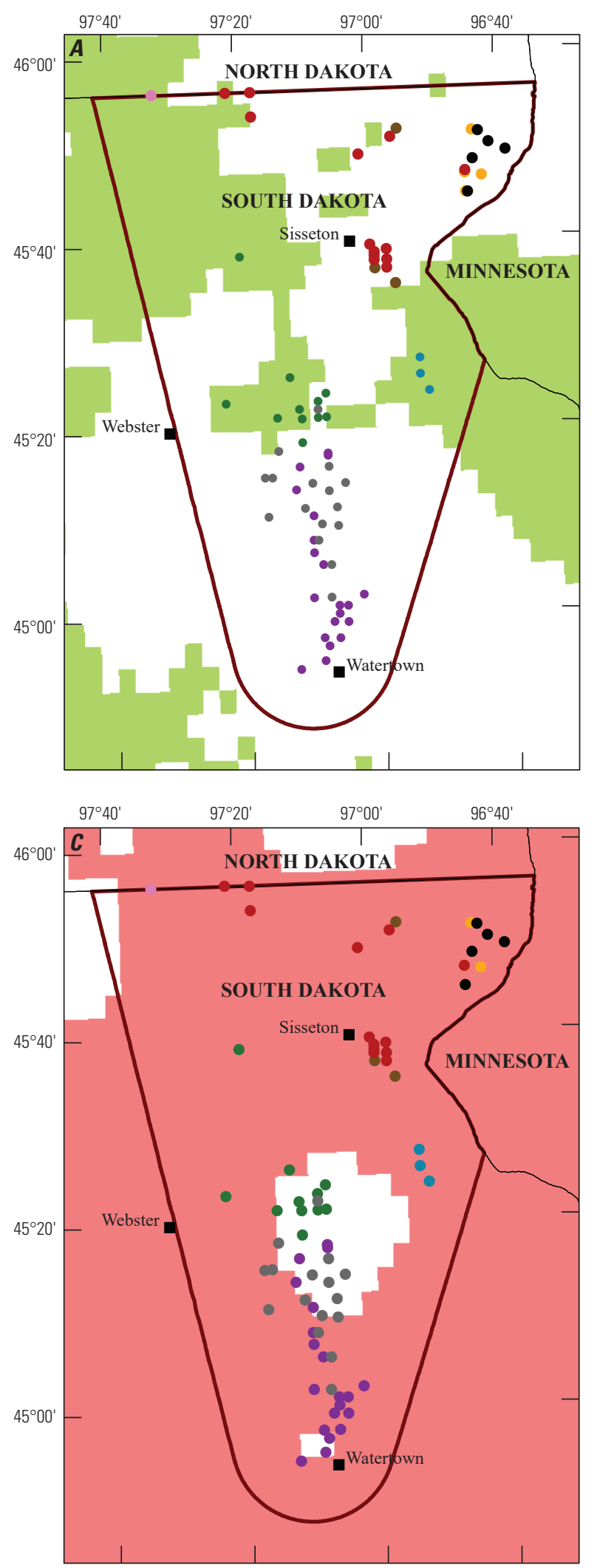

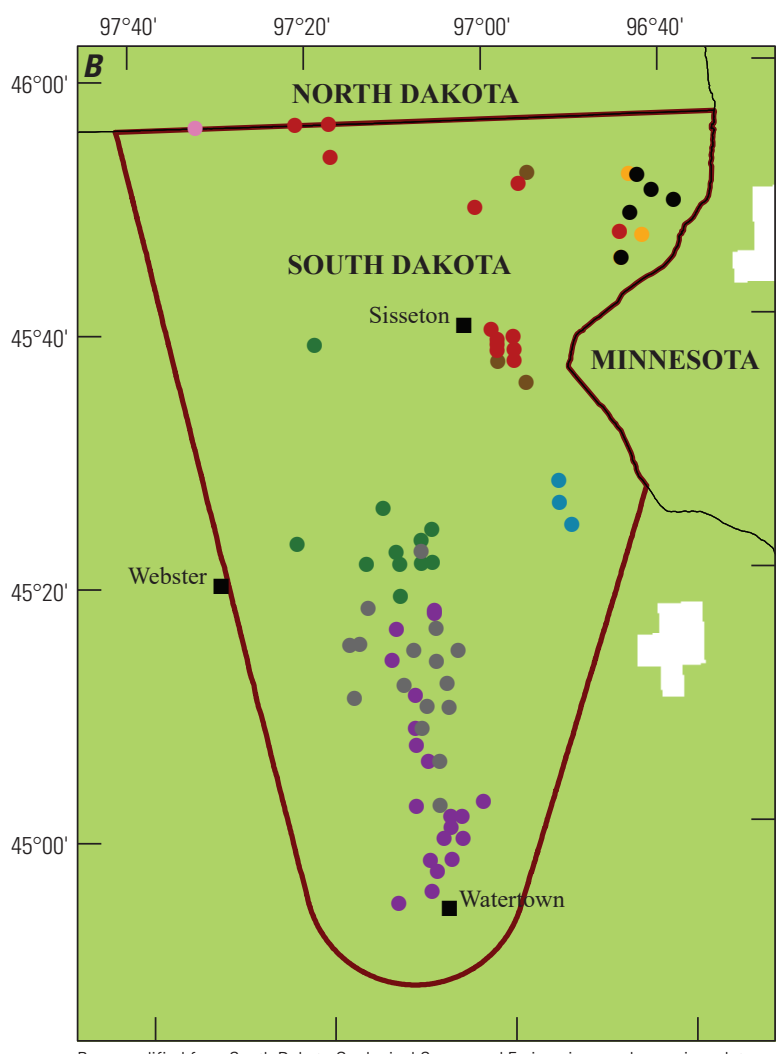

Base modified from South Dakota Geological Survey and Esri, various scales, various dates Map image is the intellectual property of Esri and is used herein under license Copyright (c) 2020 Esri and its licensors. All rights reserved

State Plane, South Dakota, South, FIPS 4002

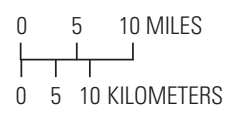

\section{EXPLANATION}

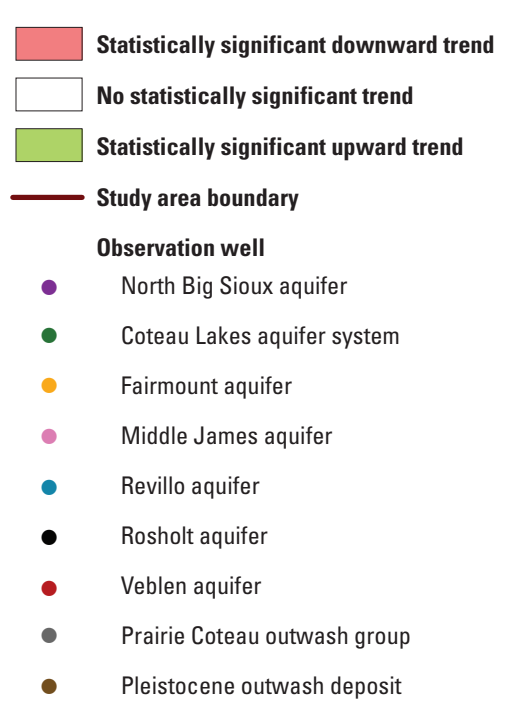

Figure 10. Spatial distribution of statistically significant trends in seasonal (July-September) climate data within the study area, water years 1956-2017. $A$, total precipitation; $B$, monthly means of daily minimum air temperature; and $C$, monthly means of daily maximum air temperature. 

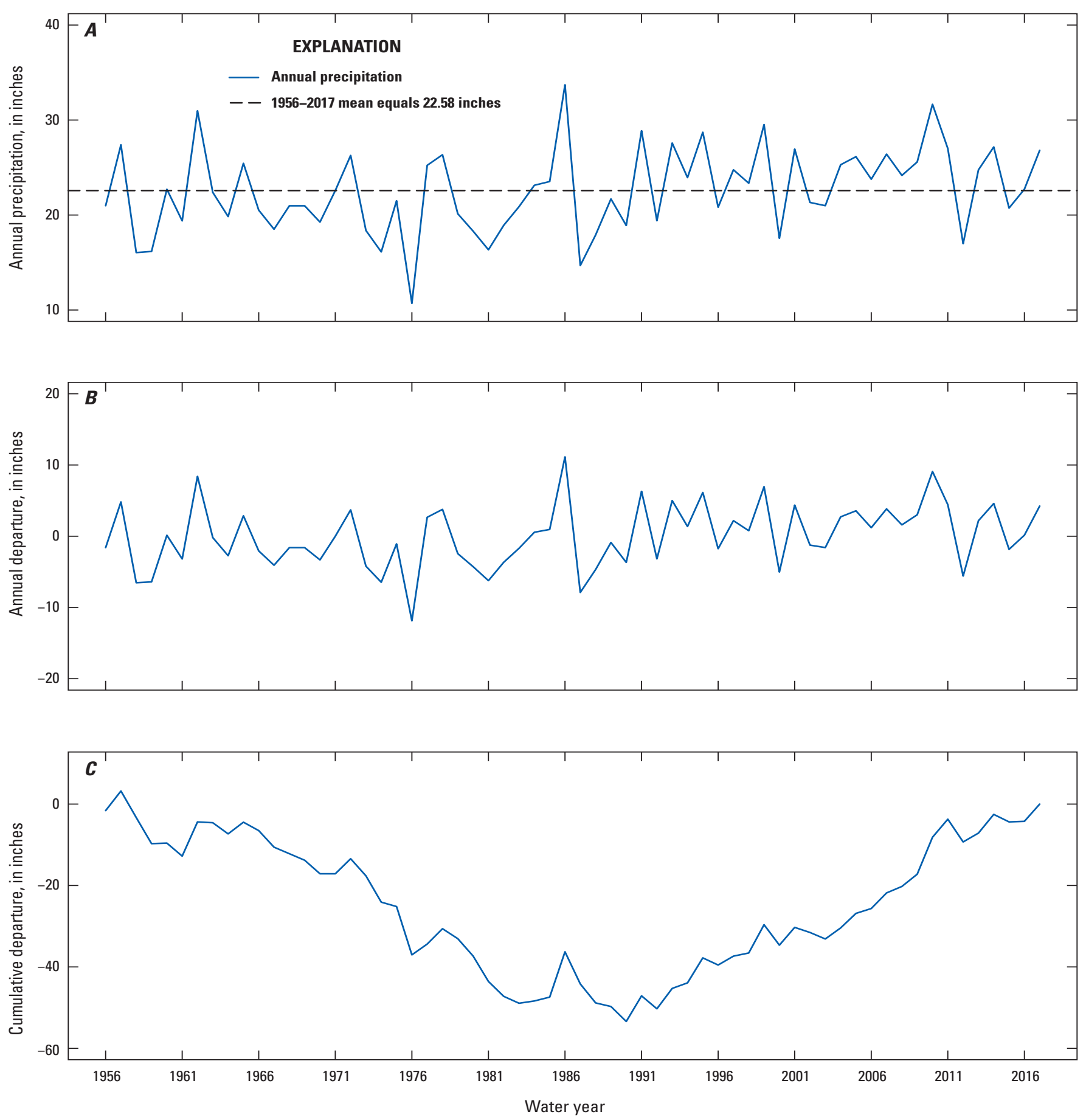

Figure 11. Annual total precipitation and departures from mean for the study area, water years 1956-2017. $A$, annual total precipitation for study area; $B$, annual departure from 1956 to 2017 mean; and $C$, cumulative annual departure from 1956 to 2017 mean. 

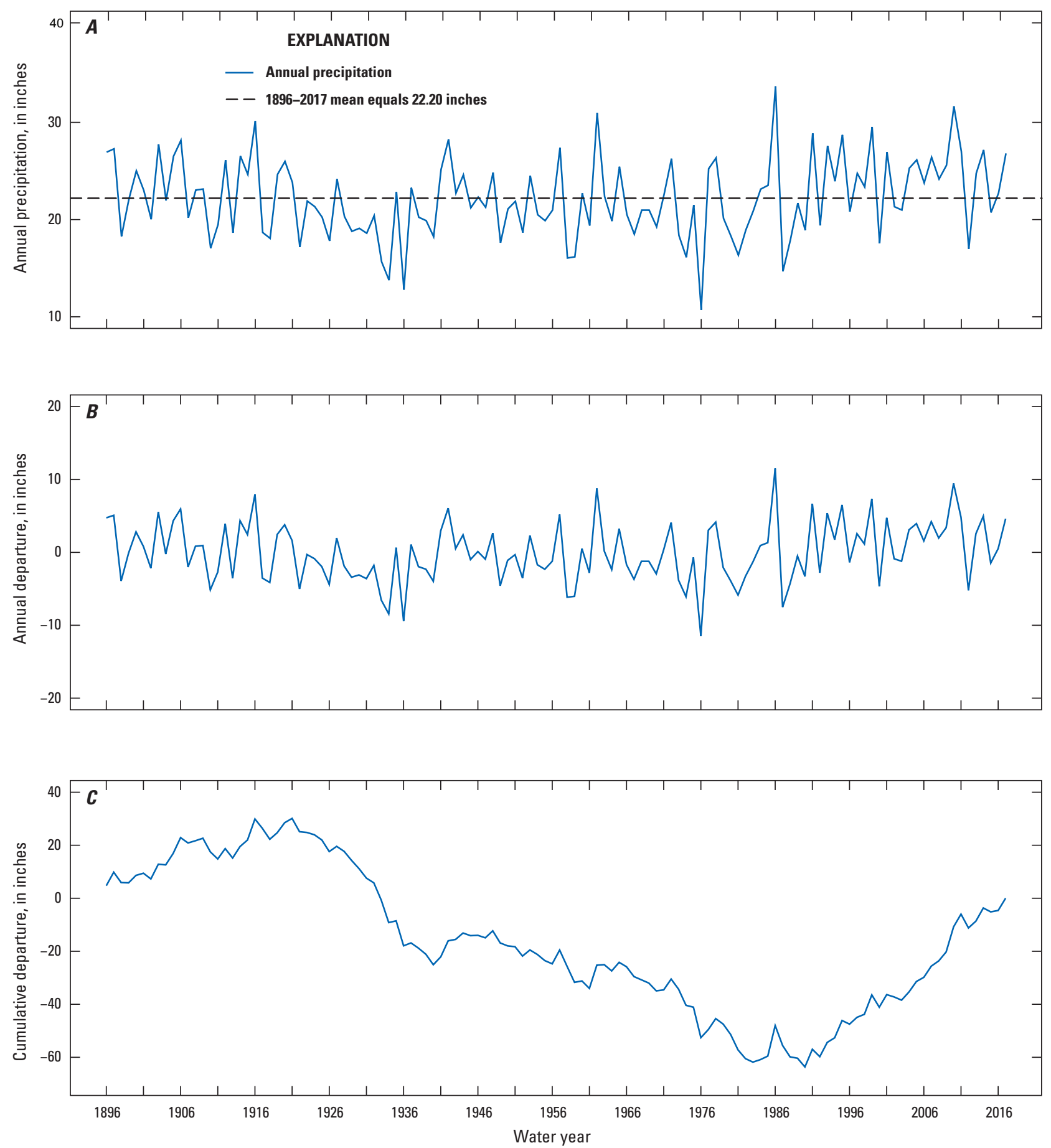

Figure 12. Annual total precipitation and departures from mean for the study area, water years 1896-2017. $A$, annual total precipitation for study area; $B$, annual departure from 1896 to 2017 mean; and $C$, cumulative departure from 1896 to 2017 mean. 
about 1990 stands out as the wettest conditions since 1896 (fig. 12C). Prolonged drought conditions persisted during 1921-41, which correspond with, but started before, the "Dust Bowl" years (1930-36). Prolonged, but less severe, dry conditions persisted from the late 1940s through the early 1980s.

Annual total precipitation within the study area was tested for trend magnitude and statistical significance for WYs 1975-2017, which includes the entire period of record for all but seven of the 76 observation wells considered (table 3 ) and, with consideration of the 2-year offset, closely matches periods of record for many wells with records starting during calendar years 1976-79. Results are summarized in table 6, along with results for the time periods considered in figures 11 and 12. The standard Mann-Kendall test was used for all three periods because statistically significant STP was not detected for any of the periods (table 6, fig 2.2). Statistically significant upward trends were indicated for 1975-2017 and 1956-2017 but not for 1896-2017. The mean precipitation during 1975-2017 was 23.14 in., which is larger than the means for 1956-2017 and 1896-2017 by 0.56 and 0.94 in., respectively. A trend magnitude was not computed for 1896-2017 because the trend was not statistically significant. The computed trend magnitudes for 1976-2017 (5.85 in.) and 1956-2017 (5.52 in.) are much larger than the increase in the mean annual precipitation from 1896 to 2017 to 1975-2017 (0.94 in.). Comparison of the statistical results of the three different time periods illustrates (1) the sensitivity of the Sen's slope estimator to the period of record that is considered and (2) that caution needs to be exercised in applying the results of testing for trend magnitudes.

\section{Interactions with Surface Water}

Interactions with surface water can affect groundwater levels in some of the glacial aquifers and outwash groups within the study area (Thompson, 2001). The North Big Sioux aquifer is hydraulically connected to the Big Sioux River, which drains the southern part of the study area, and the Veblen aquifer is hydraulically connected to the Little Minnesota River, which is a tributary to the Minnesota River (not shown on fig. 1). Many of the numerous lakes in the study area are known to have connections with groundwater (Thompson, 2001).

\section{Interactions with Rivers}

Hydrographs of annual mean streamflow for the four selected streamgages within the study area are shown in figure 13. The scope of the study did not include analysis of trends in streamflow over time. However, all four streamgages show generally similar patterns of somewhat low-flow periods during about 1974-77, 1980-83, and 1987-90, and generally higher streamflow since about 1993.
Correlation coefficients (Helsel and others, 2020) of the annual median water level for each observation well versus the annual mean streamflow for each streamgage are shown in table 7. The last column of table 7 shows the largest correlation coefficient for each well denoted with bold-face font. That coefficient also is denoted earlier in each row, with the applicable bold-face font applied in the column for the appropriate streamgage. The strongest correlations for 13 of the 20 wells completed in the North Big Sioux aquifer are with the Big Sioux River streamgage (table 7). The strongest correlations also are indicated for the Big Sioux River streamgage for 10 of the 16 wells completed in the Prairie Coteau outwash group. These correlations are generally weaker than for wells completed in the North Big Sioux aquifer; however, because all of the Prairie Coteau outwash group wells are proximal to the North Big Sioux aquifer (fig. 1), the correlations may not be entirely coincidental.

For 8 of the 11 wells completed in the Coteau Lakes aquifer system, the strongest correlations are noted for the Whetstone River ( 1 well) and Minnesota River ( 7 wells) streamgages, with 6 correlation coefficients larger than 0.7 (table 8). All these wells are substantially west of the headwaters of these rivers (fig. 1); however, these correlations may not be entirely coincidental and may be indicative of potential contributions to the base flow of these rivers from other unmapped glacial deposits located east of the mapped Coteau Lakes aquifer system (Martin and others, 2004).

For 10 of the 13 wells completed in the Veblen aquifer and for 3 of the 4 wells completed in the Fairmount aquifer, the strongest correlations are indicated for either the Bois de Sioux River or Minnesota River (table 7) streamgages. However, the wide separation between the Bois de Sioux River and the mapped extent of the Veblen aquifer (fig. 1) likely indicates that the Bois de Sioux River/Veblen aquifer correlations are largely coincidental. The strongest correlations for all five wells completed in the Rosholt aquifer (table 7) are indicated for the Bois de Sioux River streamgage. Proximal locations (fig. 1) likely indicate correlations that are not entirely coincidental.

\section{Interactions with Lakes}

Graphs showing measured water levels for 25 selected lakes (table 5) are presented in figure 14. The most noteworthy changes over time have been in the Waubay (North) Lake (fig. 14B). Niehus and others (1999) documented especially large increases in lake levels for Bitter and Waubay (North) Lakes, which are the two largest lakes within a closed basin with a collective drainage area of 409 square miles. Bitter and Waubay (North) Lakes reached levels that are unprecedented and flooded numerous farms and farmhouses and parts of several small communities in the vicinity (Niehus and others, 1999). Similar circumstances occurred throughout much of the study area, and water levels in many lakes have not since returned to water levels typical of previous conditions. 
Table 6. Results of trend analyses for annual total precipitation for the study area for three time periods.

[STP, short-term persistence; $p$-value, probability value; NA, not analyzed]

\begin{tabular}{lccccccc}
\hline $\begin{array}{c}\text { Period, in } \\
\text { water years }\end{array}$ & $\begin{array}{c}\text { STP present } \\
\text { (yes/no) }\end{array}$ & $\begin{array}{c}\text { Sen's Slope } \\
\text { (inches per year) }\end{array}$ & $\begin{array}{c}\text { Mann-Kendall } \\
\text { p-value }\end{array}$ & $\begin{array}{c}\text { Mann-Kendall } \\
\text { tau }(\tau)\end{array}$ & $\begin{array}{c}\text { Mean annual } \\
\text { precipitation for } \\
\text { period (inches) }\end{array}$ & $\begin{array}{c}\text { Number of } \\
\text { years }\end{array}$ & $\begin{array}{c}\text { Trend } \\
\text { magnitude, } \\
\text { (inches) }\end{array}$ \\
\hline 1975-2017 & No & 0.136 & 0.023 & 0.243 & 23.14 & 43 & 5.85 \\
$1956-2017$ & No & 0.089 & 0.009 & 0.228 & 22.58 & 62 & 5.52 \\
$1896-2017$ & No & 0.012 & 0.257 & 0.070 & 22.20 & 122 & NA \\
\hline
\end{tabular}

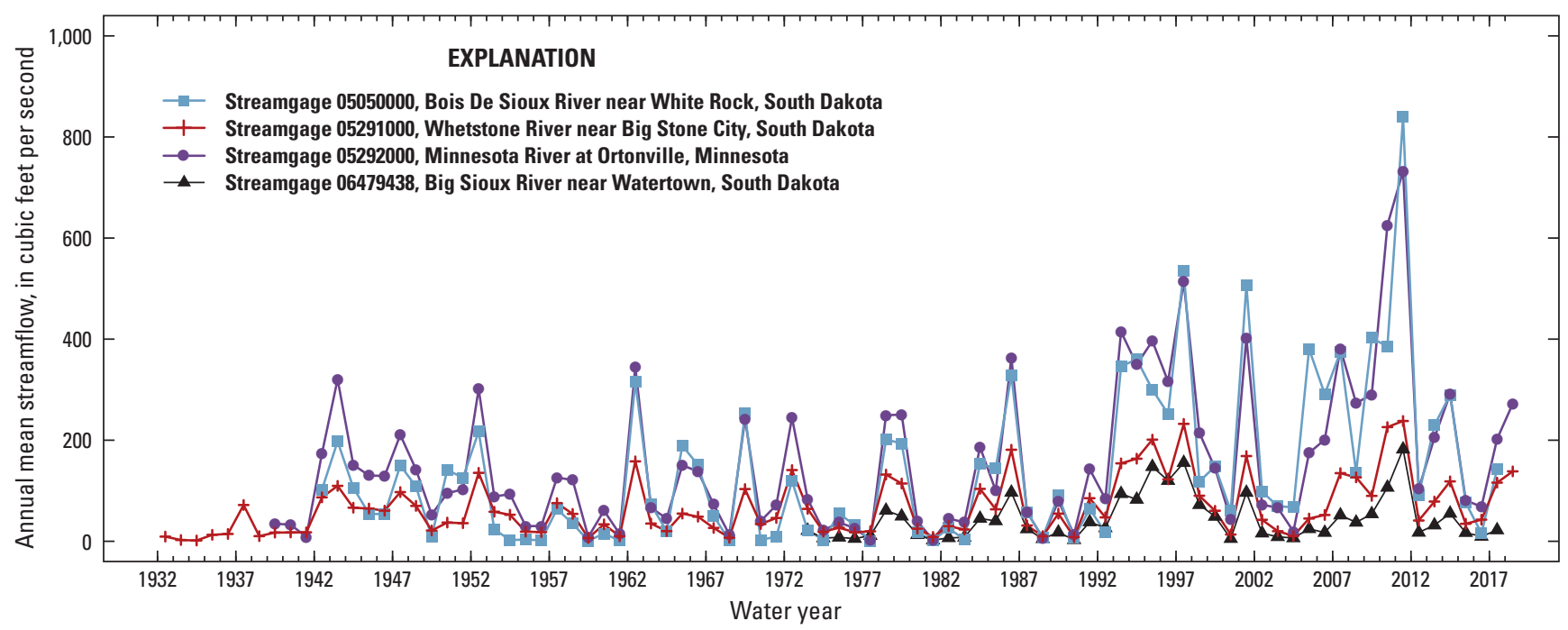

Figure 13. Hydrographs of annual mean streamflow for selected streamgages within the study area.

In response to the wet conditions of the early 1990s (fig. 11), Waubay (North) Lake began rising substantially during WY 1993, as did Bitter Lake during WY 1994 (fig. 14B). Waubay (North) Lake exceeded its outlet elevation on 1,797.1 feet (ft) (table 5) during 1996 and began spilling to Bitter Lake. During typical conditions, the level of Blue Dog Lake (fig. 14B) historically has been higher than that of Waubay (North) Lake, to which it typically spills. However, Blue Dog Lake became co-joined with Waubay (North) Lake during 1997 and has often been in a co-joined condition ever since. Somewhat similar conditions have occurred for Minnewasta and Rush Lakes (fig. 14B), which historically had water levels between those of Blue Dog and Waubay (North) Lake before about 1997.

Water levels in several other lakes shown in figure 14 also have clearly increased over time in response to the wet conditions of the early 1990s, including Nutley (East) and Piyas Lakes (fig. 14C), Drywood (North) Lake (fig. 14D), Roy Lake (fig. 14E), and Whitestone (South) Lake (fig. 14I). However, increases over time are not apparent for many of the other lakes, which is a typical condition for lakes such as Blue Dog Lake that are controlled by "spilling" over a lake outlet. Outlet elevations established by SDDENR (2019b) for selected lakes are shown in table 5. Lake Kampeska is unique from all other measured lakes considered because it is connected to the Big Sioux River by a channel just north of Watertown that has a constructed inlet/outlet structure that can control the direction of flow between the lake and river, which can occur only at high stages for the lake and the river.

Correlation coefficients (Helsel and others, 2020) for the annual median and annual maximum water levels for observation wells versus annual median water level for selected lakes are shown in table 8 (available at https://doi.org/10.3133/ sir20205151). Two rows are shown for each well, with correlation coefficients for the annual median water level listed first and correlation coefficients for the annual maximum water level listed second. The annual maximum water levels were considered because the annual median values for many wells can be affected by drawdown, which is apparent from inspection of the groundwater data. The effect of drawdown is especially true for wells having artesian conditions, for which drawdown from nearby withdrawals may be substantially larger than withdrawals for wells with water-table conditions, with differences that may approach an order of magnitude.

Special characters are shown within each row that were used as part of an approach for selecting a lake to be plotted in conjunction with water-level and precipitation data in appendix figures 1.1 through 1.76. The first step was to 
Table 7. Correlation matrix of annual median water level for observation wells versus annual mean streamflow for streamgages.

[Maximum correlation coefficients are noted with bold-face font]

\begin{tabular}{|c|c|c|c|c|c|c|}
\hline \multirow{2}{*}{$\begin{array}{l}\text { Map number } \\
\text { (fig. 1) }\end{array}$} & \multirow{2}{*}{$\begin{array}{c}\text { Well } \\
\text { number }\end{array}$} & \multicolumn{4}{|c|}{ U.S. Geological Survey streamgage number and short name } & \multirow{2}{*}{$\begin{array}{l}\text { Maximum } \\
\text { correlation } \\
\text { coefficien }\end{array}$} \\
\hline & & $\begin{array}{c}05050000 \\
\text { Bois de Sioux River }\end{array}$ & $\begin{array}{c}05291000 \\
\text { Whetstone River }\end{array}$ & $\begin{array}{c}05292000 \\
\text { Minnesota River }\end{array}$ & $\begin{array}{c}06479438 \\
\text { Big Sioux River }\end{array}$ & \\
\hline 1 & CD-56A & 0.488 & 0.622 & 0.598 & 0.642 & 0.642 \\
\hline 2 & CD-57A & 0.649 & 0.627 & 0.665 & 0.710 & 0.710 \\
\hline 5 & CD-60B & -0.167 & 0.044 & -0.064 & 0.152 & 0.152 \\
\hline 7 & CD-76B & 0.358 & 0.410 & 0.402 & 0.463 & 0.463 \\
\hline 8 & $\mathrm{CD}-76 \mathrm{C}$ & 0.661 & 0.716 & 0.723 & 0.726 & 0.726 \\
\hline 11 & CD-77B & 0.604 & 0.780 & 0.742 & 0.801 & 0.801 \\
\hline 15 & CD-81A & 0.671 & 0.696 & 0.742 & 0.705 & 0.742 \\
\hline 16 & CD-81B & 0.665 & 0.747 & 0.744 & 0.717 & 0.747 \\
\hline 17 & CD-89A & 0.652 & 0.690 & 0.732 & 0.679 & 0.732 \\
\hline 18 & CD-89B & 0.677 & 0.743 & 0.795 & 0.734 & 0.795 \\
\hline 25 & GT-57A & 0.714 & 0.777 & 0.753 & 0.753 & 0.777 \\
\hline 26 & GT-76A & 0.599 & 0.733 & 0.690 & 0.703 & 0.733 \\
\hline 30 & GT-77B & 0.579 & 0.750 & 0.722 & 0.797 & 0.797 \\
\hline 32 & GT-77D & 0.637 & 0.580 & 0.658 & 0.671 & 0.671 \\
\hline 37 & GT-82A & 0.495 & 0.670 & 0.566 & 0.643 & 0.670 \\
\hline \multicolumn{7}{|c|}{ Observation wells monitoring Prairie Coteau outwash group } \\
\hline 22 & DA-78F & 0.475 & 0.335 & 0.449 & 0.322 & 0.475 \\
\hline 23 & DA-78H & 0.369 & 0.212 & 0.325 & 0.189 & 0.369 \\
\hline 24 & DA- $82 C$ & 0.614 & 0.568 & 0.641 & 0.591 & 0.641 \\
\hline 27 & GT-76B & 0.335 & 0.403 & 0.383 & 0.468 & 0.468 \\
\hline 28 & GT-76C & 0.409 & 0.448 & 0.447 & 0.527 & 0.527 \\
\hline 29 & GT-77A & 0.403 & 0.462 & 0.458 & 0.541 & 0.541 \\
\hline 31 & GT-77C & 0.550 & 0.544 & 0.600 & 0.622 & 0.622 \\
\hline 33 & GT-77E & 0.549 & 0.533 & 0.602 & 0.657 & 0.657 \\
\hline 34 & GT-79A & 0.529 & 0.507 & 0.565 & 0.629 & 0.629 \\
\hline 35 & GT-79B & 0.426 & 0.444 & 0.461 & 0.552 & 0.552 \\
\hline 36 & GT-79C & 0.573 & 0.575 & 0.625 & 0.680 & 0.680 \\
\hline 68 & RB-93C & 0.661 & 0.793 & 0.819 & 0.799 & 0.819 \\
\hline \multicolumn{7}{|c|}{ Observation wells monitoring Coteau Lakes aquifer system } \\
\hline 19 & DA-78C & 0.450 & 0.290 & 0.416 & 0.298 & 0.450 \\
\hline 20 & DA-78D & 0.518 & 0.467 & 0.540 & 0.480 & 0.540 \\
\hline
\end{tabular}


Table 7. Correlation matrix of annual median water level for observation wells versus annual mean streamflow for streamgages.Continued

[Maximum correlation coefficients are noted with bold-face font]

\begin{tabular}{|c|c|c|c|c|c|c|}
\hline \multirow{2}{*}{$\begin{array}{l}\text { Map number } \\
\text { (fig. 1) }\end{array}$} & \multirow{2}{*}{$\begin{array}{c}\text { Well } \\
\text { number }\end{array}$} & \multicolumn{4}{|c|}{ U.S. Geological Survey streamgage number and short name } & \multirow{2}{*}{$\begin{array}{l}\text { Maximum } \\
\text { correlation } \\
\text { coefficien }\end{array}$} \\
\hline & & $\begin{array}{l}05050000 \text { Bois de } \\
\text { Sioux River }\end{array}$ & $\begin{array}{c}05291000 \\
\text { Whetstone River }\end{array}$ & $\begin{array}{c}05292000 \text { Minnesota } \\
\text { River }\end{array}$ & $\begin{array}{c}06479438 \text { Big } \\
\text { Sioux River }\end{array}$ & \\
\hline \multicolumn{7}{|c|}{ Observation wells monitoring Coteau Lakes aquifer system-Continued } \\
\hline 42 & ML-70Q & 0.631 & 0.543 & 0.643 & 0.587 & 0.643 \\
\hline 43 & RB-76A & 0.681 & 0.655 & 0.718 & 0.649 & 0.718 \\
\hline 44 & RB-76B & 0.649 & 0.705 & 0.704 & 0.659 & 0.705 \\
\hline 57 & RB-77R & 0.690 & 0.817 & 0.784 & 0.774 & 0.817 \\
\hline 58 & RB-77S & 0.697 & 0.707 & 0.751 & 0.672 & 0.751 \\
\hline 59 & RB-77T & 0.681 & 0.660 & 0.718 & 0.697 & 0.718 \\
\hline 65 & RB-81C & 0.061 & 0.198 & 0.093 & 0.325 & 0.325 \\
\hline 66 & RB-81D & 0.683 & 0.693 & 0.740 & 0.711 & 0.740 \\
\hline 67 & $\mathrm{RB}-82 \mathrm{~B}$ & 0.663 & 0.703 & 0.747 & 0.763 & 0.763 \\
\hline \multicolumn{7}{|c|}{ Observation wells monitoring Veblen aquifer system } \\
\hline 38 & ML-69A & 0.513 & 0.289 & 0.445 & 0.242 & 0.513 \\
\hline 39 & ML-70A & 0.427 & 0.226 & 0.372 & 0.173 & 0.427 \\
\hline 40 & ML-70B & 0.423 & 0.227 & 0.372 & 0.164 & 0.423 \\
\hline 52 & RB-77J & 0.482 & 0.263 & 0.415 & 0.269 & 0.482 \\
\hline 61 & RB-79B & 0.102 & 0.133 & 0.117 & 0.152 & 0.152 \\
\hline 62 & RB-79C & 0.596 & 0.555 & 0.602 & 0.574 & 0.602 \\
\hline 63 & RB-79D & 0.611 & 0.523 & 0.583 & 0.640 & 0.640 \\
\hline 64 & RB-81A & 0.418 & 0.226 & 0.372 & 0.151 & 0.418 \\
\hline 71 & RB-\#07 & 0.532 & 0.530 & 0.529 & 0.591 & 0.591 \\
\hline 73 & RB-\#11 & 0.534 & 0.412 & 0.532 & 0.390 & 0.534 \\
\hline 74 & RB-\#12 & 0.516 & 0.420 & 0.533 & 0.401 & 0.533 \\
\hline 75 & RB-\#19 & 0.476 & 0.374 & 0.487 & 0.363 & 0.487 \\
\hline 76 & RB-\#20 & 0.501 & 0.403 & 0.511 & 0.381 & 0.511 \\
\hline \multicolumn{7}{|c|}{ Observation wells monitoring Middle James aquifer } \\
\hline 41 & ML-70C & 0.416 & 0.273 & 0.405 & 0.311 & 0.416 \\
\hline \multicolumn{7}{|c|}{ Observation wells monitoring Fairmount aquifer } \\
\hline 45 & RB-77B & 0.521 & 0.334 & 0.445 & 0.484 & 0.521 \\
\hline 46 & $\mathrm{RB}-77 \mathrm{C}$ & 0.510 & 0.312 & 0.434 & 0.443 & 0.510 \\
\hline 51 & RB-77I & 0.517 & 0.324 & 0.439 & 0.476 & 0.517 \\
\hline 69 & RB-98A & 0.120 & 0.009 & 0.019 & 0.227 & 0.227 \\
\hline \multicolumn{7}{|c|}{ Observation wells monitoring Revillo aquifer } \\
\hline 54 & RB-77L & 0.472 & 0.404 & 0.455 & 0.418 & 0.472 \\
\hline 55 & RB-77M & 0.487 & 0.394 & 0.501 & 0.324 & 0.501 \\
\hline 56 & $\mathrm{RB}-77 \mathrm{~N}$ & 0.505 & 0.404 & 0.519 & 0.345 & 0.519 \\
\hline \multicolumn{7}{|c|}{ Observation wells monitoring Pleistocene aquifer } \\
\hline 60 & RB-79A & 0.656 & 0.536 & 0.637 & 0.548 & 0.656 \\
\hline 70 & RB-\#05 & 0.739 & 0.684 & 0.742 & 0.663 & 0.742 \\
\hline 72 & RB-\#10 & 0.660 & 0.572 & 0.664 & 0.560 & 0.664 \\
\hline
\end{tabular}


Table 7. Correlation matrix of annual median water level for observation wells versus annual mean streamflow for streamgages.Continued

[Maximum correlation coefficients are noted with bold-face font]

\begin{tabular}{|c|c|c|c|c|c|c|}
\hline \multirow{2}{*}{$\begin{array}{l}\text { Map number } \\
\text { (fig. 1) }\end{array}$} & \multirow{2}{*}{$\begin{array}{c}\text { Well } \\
\text { number }\end{array}$} & \multicolumn{4}{|c|}{ U.S. Geological Survey streamgage number and short name } & \multirow{2}{*}{$\begin{array}{l}\text { Maximum } \\
\text { correlation } \\
\text { coefficient }\end{array}$} \\
\hline & & $\begin{array}{l}05050000 \text { Bois de } \\
\text { Sioux River }\end{array}$ & $\begin{array}{c}05291000 \\
\text { Whetstone River }\end{array}$ & $\begin{array}{c}05292000 \text { Minnesota } \\
\text { River }\end{array}$ & $\begin{array}{c}06479438 \text { Big } \\
\text { Sioux River }\end{array}$ & \\
\hline \multicolumn{7}{|c|}{ Observation wells monitoring Rosholt aquifer } \\
\hline 47 & RB-77D & 0.604 & 0.503 & 0.592 & 0.531 & 0.604 \\
\hline 48 & RB-77E & 0.633 & 0.531 & 0.622 & 0.556 & 0.633 \\
\hline 49 & $\mathrm{RB}-77 \mathrm{~F}$ & 0.620 & 0.416 & 0.581 & 0.415 & 0.620 \\
\hline 50 & RB-77G & 0.561 & 0.447 & 0.545 & 0.443 & 0.561 \\
\hline 53 & RB-77K & 0.470 & 0.231 & 0.400 & 0.203 & 0.470 \\
\hline
\end{tabular}

examine a preliminary plot for each well that included the lake-level measurements for the nearest lake considered, which is denoted by underlining. The largest and second largest correlation coefficients for each well was for both the maximum and median annual water-level was denoted with blue, bold-faced font and red italicized font, respectively. Both coefficients are noted previously in each row, with the applicable font applied, in the columns for the two appropriate lakes. Professional judgement regarding several applicable factors was then applied in selecting a lake for final plotting with each well, with the method for selection denoted by some combination of the special characters identified above. Double underlining was used if a selected lake was not the closest lake or largest or second largest correlation. is used to show factors eliminated from the selection process (nearest lake or largest or second largest correlation coefficients). Factors considered included proximity of lakes to wells, hydrogeology, and potential effects of groundwater withdrawals, which can substantially affect measured groundwater levels and the resulting correlation coefficients. Hydrogeologic factors considered include (1) the likelihood of connection between a lake and the aquifer of completion, recognizing that large uncertainty exists in aquifer mapping because of the hydrogeologic complexity (fig. 2); (2) patterns in the plots of groundwater levels and lake levels, which can provide a perspective much different from the correlation coefficients; (3) potential that correlations between wells and lakes may also be affected by correlations between wells and streamgages; and (4) lake selection for other wells within the same aquifer (that is, "aquifer-wide" considerations).

Water levels for many lakes correlate quite strongly with each other, as shown by the correlation matrix presented in table 9 (available at https://doi.org/10.3133/sir20205151). The strongest correlation for each lake (excluding the correlation of each lake with itself) is shown in blue bold-faced font in the column for that lake (not repeated for rows). For example, the strongest correlation for Lake Kampeska is with Still Lake; however, the strongest correlation for Still Lake is with Enemy Swim Lake. Underlining is used to show five pairs of lakes that share the strongest correlations between each other. Some of the strongest correlations are among the lakes in the Waubay Lakes Chain (Bitter, Blue Dog, Minnewasta, Rush, and Waubay (North) Lake). For example, Waubay (North) Lake and Nutley (East) Lake share a common strongest correlation coefficient of 0.981 (table 9). Conversely, correlations among many of the lakes are very weak, or even negative. A myriad of other lakes without available water-level data are located within the study area that presumably interact with groundwater in many of the aquifers considered. A wide range in characteristics of water-level changes would be anticipated for the myriad lakes, based on the correlations provided in table 9.

Correlation coefficients from table 8 were used in selecting an appropriate lake for plotting with the time-trend analyses for each observation well (appendix figs. 1.1 through 1.76). In many cases, groundwater levels in observation wells can have strong resemblance to water levels in one or more area lakes. However, it is recognized that in many cases the selected lake likely is not hydraulically connected with a groundwater system or aquifer associated with an individual well, especially in cases of increasing distance between a lake and well. However, a lake was selected for plotting with every well to provide perspectives on (1) potential interactions between groundwater and other lakes that may fluctuate similar to the selected lake; and (2) various other factors that might affect groundwater fluctuations for each well, such as effects of groundwater withdrawals (a general expectation that correlation coefficients would decrease with increasing demand), which for some of the wells considered are much more apparent when well and lake hydrographs are viewed simultaneously. Wells CD-56A and CD-57A (map numbers 1 and 2, fig. 1, table 7) provide examples of wells where the correlation coefficient for the maximum annual water level is higher than for the median (both for Still Lake), which likely results from effects of proximal licensed groundwater withdrawals (slightly over $40 \mathrm{ft} 3 / \mathrm{s}$ within a 5 -mi radius for both wells, as of 2017) (table 8). Of the 20 North Big Sioux aquifer wells, 10 have at least one correlation coefficient larger than 0.7 for either Lake 


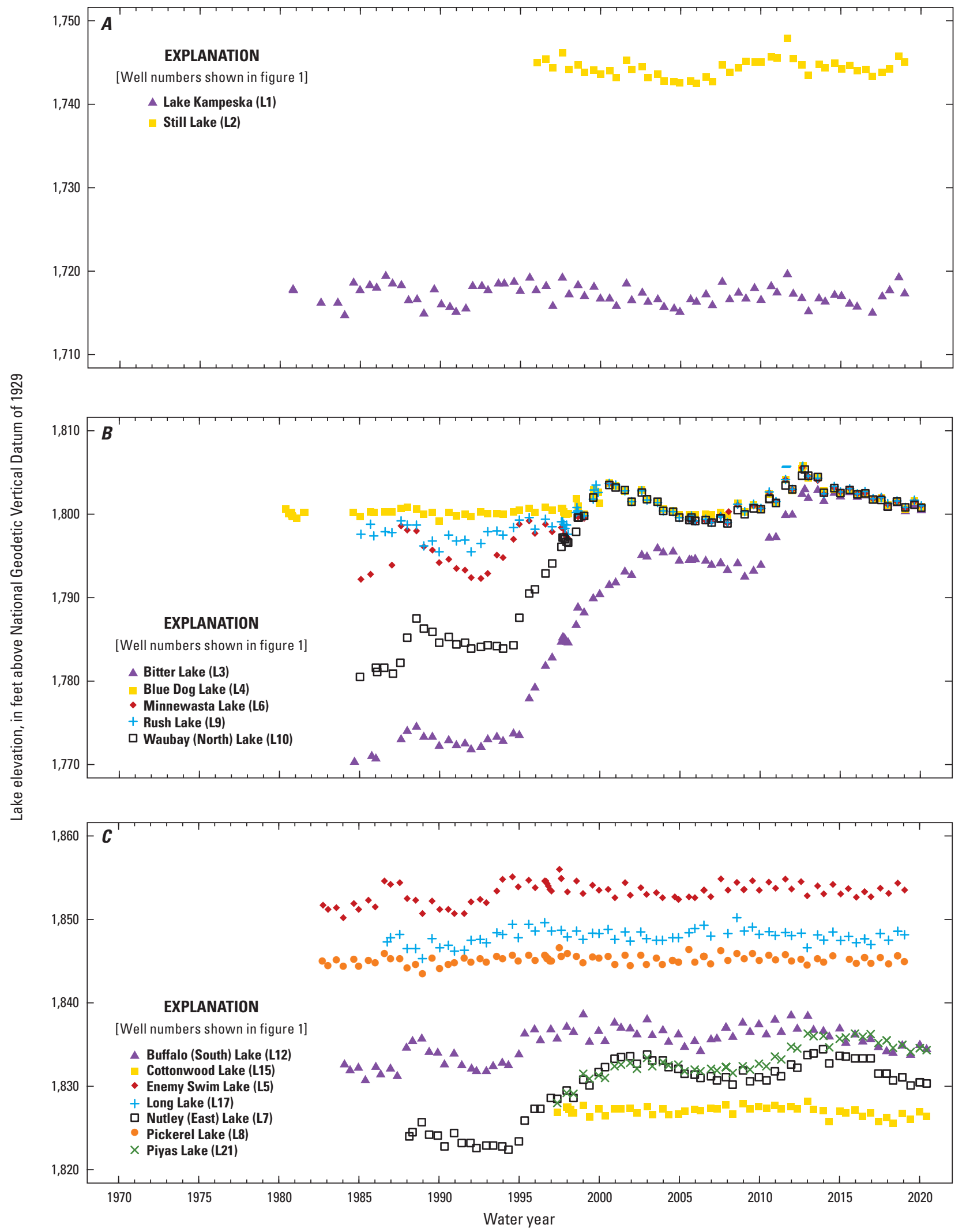

Figure 14. Hydrographs of measured lake levels for selected lakes within the study area. $A$, Lake Kampeska and Still Lake. $B$, Bitter, Blue Dog, Minnewasta, Rusk, and Waubay (North) Lakes. C, Buffalo (South), Cottonwood, Enemy Swim, Long, Nutley (East), Pickerel, and Piyas Lakes. D, Drywood (North) and Twin Lakes. E, Bullhead, Four Mile, and Roy Lakes. F, Clear, Nine Mile, and Red Iron (North) Lakes. G, Cottonwood (North) Lake. H, Hurricane Lake. I, Whitestone (South) Lake. 


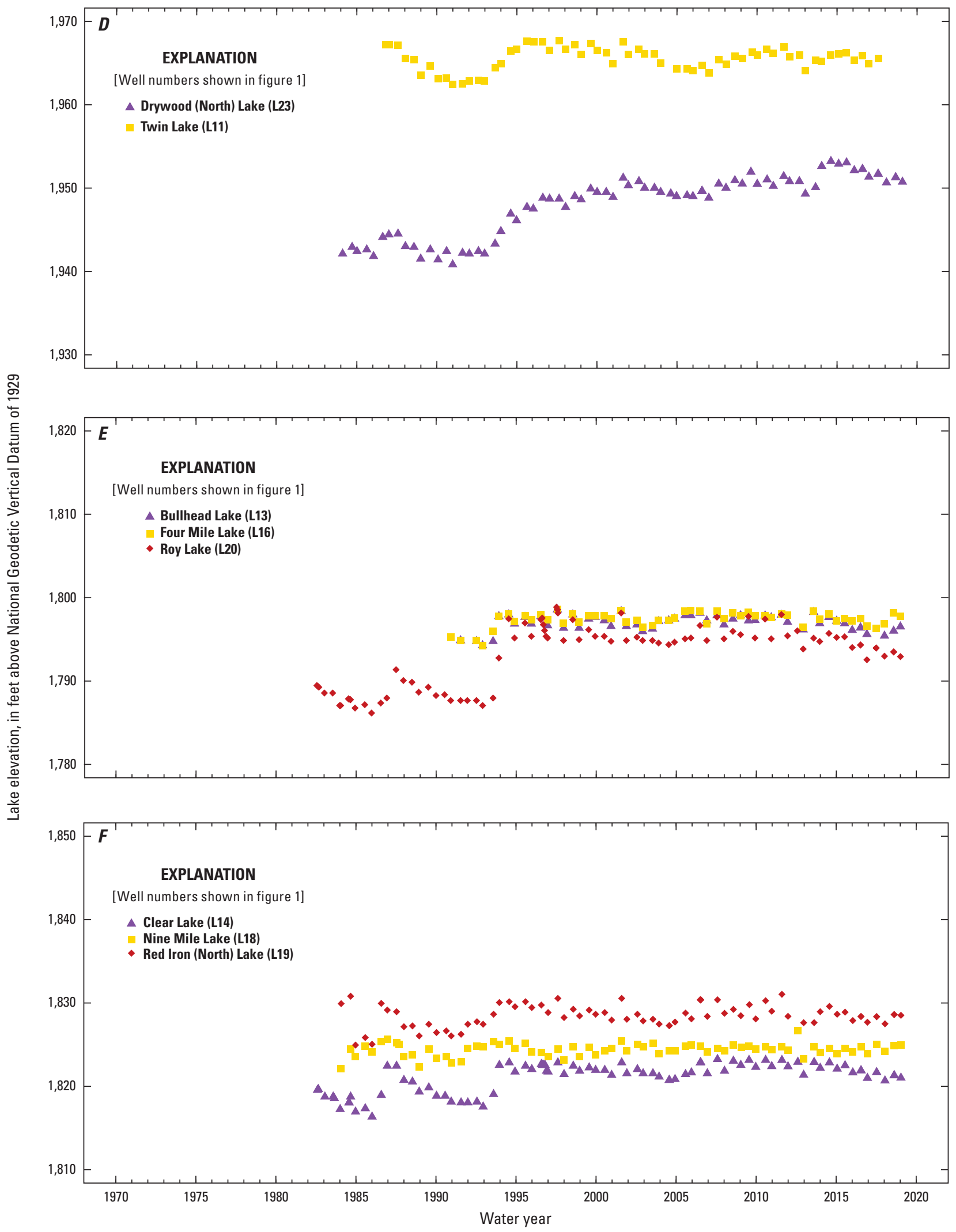

Figure 14. Hydrographs of measured lake levels for selected lakes within the study area. A, Lake Kampeska and Still Lake. $B$, Bitter, Blue Dog, Minnewasta, Rusk, and Waubay (North) Lakes. C, Buffalo (South), Cottonwood, Enemy Swim, Long, Nutley (East), Pickerel, and Piyas Lakes. D, Drywood (North) and Twin Lakes. E, Bullhead, Four Mile, and Roy Lakes. F, Clear, Nine Mile, and Red Iron (North) Lakes. G, Cottonwood (North) Lake. H, Hurricane Lake. I, Whitestone (South) Lake.-Continued 


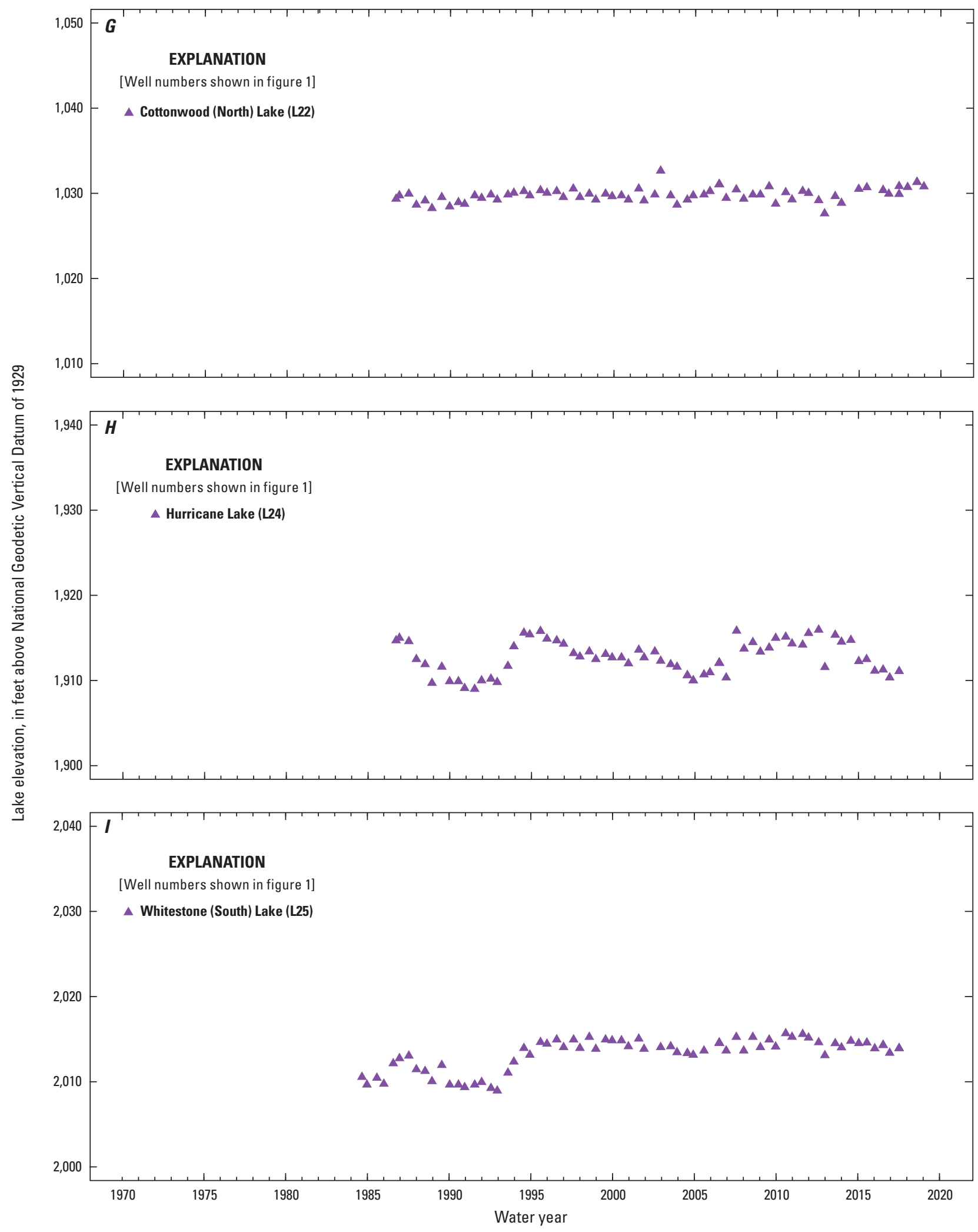

Figure 14. Hydrographs of measured lake levels for selected lakes within the study area. $A$, Lake Kampeska and Still Lake. $B$, Bitter, Blue Dog, Minnewasta, Rusk, and Waubay (North) Lakes. C, Buffalo (South), Cottonwood, Enemy Swim, Long, Nutley (East), Pickerel, and Piyas Lakes. D, Drywood (North) and Twin Lakes. E, Bullhead, Four Mile, and Roy Lakes. F, Clear, Nine Mile, and Red Iron (North) Lakes. G, Cottonwood (North) Lake. H, Hurricane Lake. I, Whitestone (South) Lake.-Continued. 
Kampeska or Still Lake, essentially explaining about 49 percent or more of the variability in groundwater levels with lake-level records.

\section{Analysis of Factors Affecting Groundwater Levels}

Trends over time for groundwater levels and for annual precipitation for the 76 observation wells considered are presented in appendix figures 1.1 through 1.76. These figures also show measured water levels for a selected lake and licensed groundwater withdrawals (where applicable) over time within six specified radii of each well. Complete results of statistical trend analyses for the 76 observation wells are presented in appendix table 2.1. The modified Mann-Kendall test was used for testing of all three water-level parameters because statistically significant STP was detected for most of the water-level datasets (table 2.2; figs. 2.3-2.78). Table 2.1 also includes results of statistical analyses for annual total precipitation for the location of each observation well. The standard Mann-Kendall test was used for testing of precipitation trends because statistically significant STP was not detected in any of the annual precipitation datasets.

Primary results of trend testing for the 76 observation wells are summarized in table 10, which is sorted by aquifer to facilitate characterizations of results by aquifer. For each well, statistically significant upward trends for any of the three water-level parameters are denoted with bold-face font and statistically significant downward trends are denoted with italicized font. Of all 76 wells considered, 43 wells have significant upward trends for at least one of the three waterlevel parameters, 8 wells have significant downward trends for at least one parameter, and 25 wells do not have any significant trends.

Trends in annual total precipitation for the location of each observation well also are shown in table 10. Statistically significant upward trends are shown for 43 wells and nonsignificant trends are shown for 33 wells. Most of the wells with nonsignificant trends are completed in the Big Sioux aquifer or Prairie Coteau outwash group and are located in Codington, Day, or Grant Counties in the southern part of the study area (fig. 1) where precipitation trends for 1957-2017 are predominantly nonsignificant (fig. 6). For the entire study area, precipitation trended upward for 1975-2017 (table 7); however, it is noted that for any given well, the precipitation trend is affected by location and the period of record considered.

Of the 20 wells completed in the North Big Sioux aquifer, only one has a significant upward trend for precipitation. However, four wells have significant upward trends for all three water-level parameters and two other wells have significant upward trends for at least one parameter. Two wells completed in the North Big Sioux aquifer have significant downward trends for all three water-level parameters. Magnitudes of water-level trends, computed as the product of the applicable period of record and the Sen's slope for the median value, for all wells that have statistically significant trends for at least one of the three water-level parameters are shown in table 10.

Locations of the eight wells completed in the North Big Sioux aquifer with significant trends for at least one waterlevel parameter are shown in figure 15. Licensed groundwater withdrawals within 0.5 and $1.0 \mathrm{mi}$ radii of each observation well are shown in figure 3 and are summarized in table 10 , along with withdrawals for radii of 2.0, 3.0, 4.0, and $5.0 \mathrm{mi}$. The two wells with significant downward trends for all three water-level parameters have withdrawals of 54.5 and $53.4 \mathrm{ft} 3 / \mathrm{s}$ within $5 \mathrm{mi}$, respectively. All six wells with significant upward trends for at least one water-level parameter have licensed groundwater withdrawals totaling at least $39.5 \mathrm{ft} 3 / \mathrm{s}$ within $5 \mathrm{mi}$. It seems contradictory to have generally nonsignificant to upward trends in groundwater levels in spite of generally nonsignificant precipitation trends and substantially large groundwater demand; however, 19 of the 20 wells completed in the North Big Sioux aquifer have upward precipitation trends that are not statistically significant. The potential contradiction may also be indicative of a regional-scale hydroclimatic condition, such as elevated water levels in myriad lakes and wetlands throughout the study area, as a contributing driving factor for groundwater conditions. The nonsignificant trends could indicate that Big Sioux aquifer is losing or has withdrawals equal to recharge, however, additional information would be needed to make this determination.

Potential interactions between streamflow, lakes, and groundwater levels in the North Big Sioux aquifer, which is hydraulically connected with the North Big Sioux River (Thompson, 2001), were examined previously in the "Interactions with Surface Water" section. Correlation coefficients between groundwater levels and flow of the Big Sioux River exceed 0.8 for 5 of the 20 wells completed in the North Big Sioux aquifer (table 8). The only other wells in table 8 with correlation coefficients exceeding 0.8 are wells RB-93C (Prairie Coteau outwash group) and RB-77R (Coteau Lakes aquifer). Correlation coefficients between lakes and groundwater levels indicate generally strong correlations for wells completed in the North Big Sioux aquifer with either Lake Kampeska or Still Lake (table 8). Lake Kampeska or Still Lake are listed as either the strongest or second strongest correlation for either annual median or annual maximum for all but 3 of 20 wells (CD-81A, GT-57A, and GT-77D), which likely results from a hydraulic connection between the lakes and the North Big Sioux aquifer (fig. 1).

Analyses for the 20 wells that are completed in the North Big Sioux aquifer are provided in figures 1.1 through 1.20. Measured water levels for well GT-77D for Waubay (North) Lake are shown in figure 1.19B. Lake Kampeska was selected for plotting for all 19 of the other wells that are completed in the North Big Sioux aquifer. Lake Kampeska or Still Lake (lakes L1 and L2, respectively) is identified in table 8 as the closest lake for 15 of the 20 wells, and Lake Kampeska was preferentially selected over Still Lake for plotting for all of these wells because the period of record is longer by 
[Start year, first water year for statistical analysis; ft/yr, feet/year; Mod M-K, modified Mann-Kendall; p-value, probability value; M-K, Mann-Kendall; in/yr, inch per year; Years, years of water-level record; $<$, less than; --, not applicable; Up, number of statistically significant upward trends, Down, number of statistically significant downward trends. Statistically significant upward trends (positive Sen's slope with p-value less than or equal to 0.10 ) are noted with bold-face font and statistically significant downward trends (negative Sen's slope) are noted with italics]

\begin{tabular}{|c|c|c|c|c|c|c|c|c|c|c|c|c|c|c|}
\hline \multirow{2}{*}{$\begin{array}{c}\text { Map } \\
\text { number }\end{array}$} & \multirow{2}{*}{$\begin{array}{c}\text { Well } \\
\text { number }\end{array}$} & \multirow{2}{*}{$\begin{array}{l}\text { Start } \\
\text { year }\end{array}$} & \multicolumn{2}{|c|}{$\begin{array}{c}\text { Annual minimum water } \\
\text { level }\end{array}$} & \multicolumn{2}{|c|}{$\begin{array}{c}\text { Annual median water } \\
\text { level }\end{array}$} & \multicolumn{2}{|c|}{$\begin{array}{c}\text { Annual maximum water } \\
\text { level }\end{array}$} & \multirow{2}{*}{$\begin{array}{l}\text { Start } \\
\text { year }\end{array}$} & \multicolumn{2}{|c|}{$\begin{array}{l}\text { Annual total } \\
\text { precipitation }\end{array}$} & \multicolumn{3}{|c|}{$\begin{array}{l}\text { Licensed groundwater } \\
\text { withdrawals, in cubic feet } \\
\text { per second, within specified } \\
\text { radius of well, in miles }\end{array}$} \\
\hline & & & $\begin{array}{c}\text { Sen's Slope } \\
\text { (ft/yr) }\end{array}$ & $\begin{array}{c}\text { Mod M-K } \\
p \text {-value }\end{array}$ & $\begin{array}{c}\text { Sen's Slope } \\
\text { (ft/yr) }\end{array}$ & $\begin{array}{l}\text { Mod M-K } \\
p \text {-value }\end{array}$ & $\begin{array}{c}\text { Sen's Slope } \\
\text { (ft/yr) }\end{array}$ & $\begin{array}{c}\text { Mod M-K } \\
p \text {-value }\end{array}$ & & $\begin{array}{c}\text { Sen's Slope } \\
\text { (in/yr) }\end{array}$ & $\begin{array}{c}\text { M-K } \\
p \text {-value }\end{array}$ & 0.5 & 1.0 & 5.0 \\
\hline \multicolumn{15}{|c|}{ Observation wells monitoring North Big Sioux aquifer } \\
\hline 1 & CD-56A & 1957 & 0.021 & 0.002 & 0.020 & $<0.001$ & 0.033 & $<0.001$ & 1956 & 0.046 & 0.170 & 1.0 & 3.8 & 40.2 \\
\hline 2 & CD-57A & 1957 & 0.100 & $<0.001$ & 0.113 & $<0.001$ & 0.120 & $<0.001$ & 1956 & 0.025 & 0.395 & 0.0 & 2.7 & 40.7 \\
\hline 3 & CD-59A & 1960 & 0.044 & 0.006 & 0.052 & 0.003 & 0.046 & 0.020 & 1958 & 0.050 & 0.124 & 0.0 & 1.6 & 46.5 \\
\hline 4 & CD-60A & 1960 & 0.008 & 0.495 & 0.014 & 0.254 & 0.015 & 0.373 & 1958 & 0.048 & 0.204 & 0.0 & 0.0 & 41.3 \\
\hline 5 & CD-60B & 1960 & -0.053 & $<0.001$ & -0.057 & $<0.001$ & -0.044 & 0.007 & 1958 & 0.049 & 0.134 & 0.0 & 4.9 & 54.5 \\
\hline 7 & CD-76B & 1977 & -0.031 & 0.013 & -0.035 & 0.024 & -0.048 & 0.018 & 1975 & 0.032 & 0.572 & 7.1 & 8.0 & 53.4 \\
\hline 8 & CD-76C & 1977 & 0.015 & 0.120 & 0.001 & 0.787 & -0.003 & 0.515 & 1975 & 0.041 & 0.426 & 1.9 & 1.9 & 28.1 \\
\hline 11 & CD-77B & 1978 & 0.004 & 0.723 & -0.003 & 0.890 & -0.010 & 0.651 & 1976 & 0.070 & 0.251 & 0.0 & 2.7 & 28.0 \\
\hline 12 & CD-77C & 1978 & 0.006 & 0.803 & 0.005 & 0.852 & 0.004 & 0.898 & 1976 & 0.066 & 0.251 & 0.0 & 0.0 & 25.4 \\
\hline 13 & $\mathrm{CD}-77 \mathrm{~F}$ & 1978 & 0.015 & 0.582 & 0.009 & 0.820 & -0.004 & 0.901 & 1976 & 0.030 & 0.618 & 1.3 & 4.2 & 54.3 \\
\hline 14 & CD-79A & 1980 & -0.013 & 0.637 & -0.006 & 0.869 & 0.000 & 1.000 & 1978 & 0.040 & 0.584 & 1.7 & 3.3 & 35.0 \\
\hline 15 & CD-81A & 1981 & 0.051 & 0.117 & 0.068 & 0.055 & 0.055 & 0.047 & 1979 & 0.025 & 0.628 & 0.0 & 1.8 & 53.2 \\
\hline 16 & CD-81B & 1981 & 0.052 & 0.207 & 0.057 & 0.100 & 0.032 & 0.300 & 1979 & 0.029 & 0.595 & 0.0 & 0.0 & 47.1 \\
\hline 17 & CD-89A & 1989 & 0.012 & 0.548 & 0.016 & 0.615 & 0.007 & 0.905 & 1987 & 0.092 & 0.455 & 2.9 & 7.3 & 39.4 \\
\hline 18 & CD-89B & 1989 & -0.012 & 0.491 & -0.014 & 0.610 & -0.017 & 0.589 & 1987 & 0.091 & 0.434 & 3.3 & 4.4 & 49.9 \\
\hline 25 & GT-57A & 1957 & 0.031 & $<0.001$ & 0.037 & $<0.001$ & 0.050 & $<0.001$ & 1956 & 0.074 & 0.040 & 0.0 & 0.0 & 39.5 \\
\hline 26 & GT-76A & 1977 & -0.024 & 0.219 & -0.006 & 0.630 & 0.013 & 0.567 & 1975 & 0.081 & 0.127 & 3.5 & 6.6 & 45.8 \\
\hline 30 & GT-77B & 1978 & -0.010 & 0.544 & 0.003 & 0.914 & 0.009 & 0.644 & 1976 & 0.102 & 0.146 & 6.2 & 12.1 & 60.4 \\
\hline 32 & GT-77D & 1978 & 0.091 & 0.359 & 0.079 & 0.355 & 0.080 & 0.331 & 1976 & 0.089 & 0.193 & 0.7 & 2.8 & 64.0 \\
\hline 37 & GT-82A & 1982 & 0.008 & 0.468 & -0.009 & 0.363 & -0.009 & 0.548 & 1980 & 0.104 & 0.227 & 0.0 & 0.0 & 35.2 \\
\hline \multirow{3}{*}{\multicolumn{2}{|c|}{$\begin{array}{c}\text { Totals for trend } \\
\text { analyses }\end{array}$}} & Up & 4 & -- & 6 & -- & 5 & -- & -- & 1 & -- & -- & -- & -- \\
\hline & & Down & 2 & -- & 2 & -- & 2 & -- & -- & 0 & -- & -- & -- & -- \\
\hline & & No trend & 14 & -- & 12 & -- & 13 & -- & -- & 19 & -- & -- & -- & -- \\
\hline
\end{tabular}


Table 10. Summary of results of trend analyses for water levels and annual total precipitation at observation wells.-Continued

[Start year, first water year for statistical analysis; ft/yr, feet/year; Mod M-K, modified Mann-Kendall; p-value, probability value; M-K, Mann-Kendall; in/yr, inch per year; Years, years of water-level record; $<$, less than; --, not applicable; Up, number of statistically significant upward trends, Down, number of statistically significant downward trends. Statistically significant upward trends (positive Sen's slope with p-value less than or equal to 0.10 ) are noted with bold-face font and statistically significant downward trends (negative Sen's slope) are noted with italics]

\begin{tabular}{|c|c|c|c|c|c|c|c|c|c|c|c|c|c|c|}
\hline \multirow[t]{2}{*}{$\begin{array}{c}\text { Map } \\
\text { number }\end{array}$} & \multirow[t]{2}{*}{$\begin{array}{c}\text { Well } \\
\text { number }\end{array}$} & \multirow[t]{2}{*}{$\begin{array}{l}\text { Start } \\
\text { year }\end{array}$} & \multicolumn{2}{|c|}{$\begin{array}{c}\text { Annual minimum water } \\
\text { level }\end{array}$} & \multicolumn{2}{|c|}{$\begin{array}{c}\text { Annual median water } \\
\text { level }\end{array}$} & \multicolumn{2}{|c|}{$\begin{array}{c}\text { Annual maximum water } \\
\text { level }\end{array}$} & \multirow[t]{2}{*}{$\begin{array}{l}\text { Start } \\
\text { year }\end{array}$} & \multicolumn{2}{|c|}{$\begin{array}{l}\text { Annual total } \\
\text { precipitation }\end{array}$} & \multicolumn{3}{|c|}{$\begin{array}{l}\text { Licensed groundwater } \\
\text { withdrawals, in cubic feet } \\
\text { per second, within specified } \\
\text { radius of well, in miles }\end{array}$} \\
\hline & & & $\begin{array}{c}\text { Sen's Slope } \\
\text { (ft/yr) }\end{array}$ & $\begin{array}{l}\text { Mod M-K } \\
p \text {-value }\end{array}$ & $\begin{array}{c}\text { Sen's Slope } \\
\text { (ft/yr) }\end{array}$ & $\begin{array}{l}\text { Mod M-K } \\
p \text {-value }\end{array}$ & $\begin{array}{c}\text { Sen's Slope } \\
\text { (ft/yr) }\end{array}$ & $\begin{array}{l}\text { Mod M-K } \\
p \text {-value }\end{array}$ & & $\begin{array}{c}\text { Sen's Slope } \\
\text { (in/yr) }\end{array}$ & $\begin{array}{c}\text { M-K } \\
p \text {-value }\end{array}$ & 0.5 & 1.0 & 5.0 \\
\hline \multicolumn{15}{|c|}{ Observation wells monitoring Prairie Coteau aquifer } \\
\hline 6 & CD-76A & 1977 & -0.477 & 0.005 & -0.064 & 0.343 & 0.018 & 0.382 & 1975 & 0.064 & 0.250 & 1.8 & 1.8 & 28.4 \\
\hline 9 & CD-76D & 1976 & -0.757 & 0.028 & -0.044 & 0.658 & 0.005 & 0.851 & 1974 & 0.102 & 0.077 & 5.9 & 7.9 & 40.2 \\
\hline 10 & CD-77A & 1981 & -0.045 & 0.399 & 0.092 & 0.082 & 0.076 & 0.070 & 1979 & 0.039 & 0.529 & 0.0 & 1.1 & 40.5 \\
\hline 21 & DA-78E & 1978 & 0.564 & $<0.001$ & 0.486 & $<0.001$ & 0.467 & $<0.001$ & 1976 & 0.096 & 0.146 & 1.1 & 1.1 & 27.6 \\
\hline 22 & DA-78F & 1978 & 0.438 & $<0.001$ & 0.401 & $<0.001$ & 0.382 & $<0.001$ & 1976 & 0.104 & 0.141 & 0.0 & 5.6 & 35.8 \\
\hline 23 & DA-78H & 1979 & 0.386 & $<0.001$ & 0.393 & $<0.001$ & 0.401 & $<0.001$ & 1977 & 0.059 & 0.375 & 0.0 & 0.0 & 14.0 \\
\hline 24 & DA-82C & 1982 & 0.303 & 0.099 & 0.268 & 0.101 & 0.244 & 0.164 & 1980 & 0.143 & 0.056 & 0.0 & 0.0 & 54.9 \\
\hline 27 & GT-76B & 1977 & -0.411 & 0.158 & -0.054 & 0.615 & 0.028 & 0.450 & 1975 & 0.080 & 0.132 & 1.0 & 2.0 & 49.4 \\
\hline 28 & GT-76C & 1977 & -0.388 & 0.072 & -0.031 & 0.796 & 0.061 & 0.260 & 1975 & 0.090 & 0.098 & 0.0 & 0.0 & 50.7 \\
\hline 29 & GT-77A & 1977 & -0.400 & 0.141 & -0.069 & 0.524 & 0.045 & 0.369 & 1975 & 0.085 & 0.132 & 0.0 & 4.3 & 56.3 \\
\hline 31 & GT-77C & 1978 & -0.068 & 0.664 & 0.069 & 0.257 & 0.100 & 0.092 & 1976 & 0.086 & 0.209 & 0.0 & 0.0 & 62.9 \\
\hline 33 & GT-77E & 1978 & -0.013 & 0.876 & 0.032 & 0.535 & 0.032 & 0.585 & 1976 & 0.091 & 0.242 & 0.0 & 0.0 & 30.2 \\
\hline 34 & GT-79A & 1982 & -0.100 & 0.419 & 0.034 & 0.773 & 0.069 & 0.441 & 1980 & 0.099 & 0.258 & 0.0 & 0.0 & 38.8 \\
\hline 35 & GT-79B & 1980 & -0.235 & 0.350 & -0.004 & 0.970 & 0.041 & 0.525 & 1978 & 0.074 & 0.279 & 0.0 & 0.0 & 59.5 \\
\hline 36 & GT-79C & 1980 & -0.046 & 0.788 & 0.053 & 0.506 & 0.080 & 0.225 & 1978 & 0.069 & 0.258 & 0.0 & 0.0 & 59.0 \\
\hline 68 & RB-93C & 1994 & -0.100 & 0.157 & -0.081 & 0.010 & -0.076 & 0.008 & 1992 & 0.069 & 0.724 & 0.0 & 11.3 & 45.3 \\
\hline \multirow{3}{*}{\multicolumn{2}{|c|}{$\begin{array}{c}\text { Totals for trend } \\
\text { analyses }\end{array}$}} & Up & 4 & -- & 4 & -- & 4 & -- & -- & 3 & -- & -- & -- & -- \\
\hline & & Down & 3 & -- & 1 & -- & 1 & -- & -- & 0 & -- & -- & -- & -- \\
\hline & & No trend & 9 & -- & 11 & -- & 11 & -- & -- & 13 & -- & -- & -- & -- \\
\hline \multicolumn{15}{|c|}{ Observation wells monitoring Coteau Lakes aquifer system } \\
\hline 19 & DA-78C & 1978 & 0.297 & 0.068 & 0.585 & 0.003 & 0.599 & $<0.001$ & 1976 & 0.150 & 0.009 & 4.5 & 5.8 & 9.5 \\
\hline 20 & DA-78D & 1978 & 0.146 & 0.006 & 0.099 & 0.007 & 0.076 & 0.006 & 1976 & 0.165 & 0.008 & 2.6 & 2.6 & 43.8 \\
\hline 42 & ML-70Q & 1978 & 0.132 & 0.128 & 0.155 & 0.058 & 0.162 & 0.069 & 1976 & 0.160 & 0.009 & 0.0 & 0.0 & 0.1 \\
\hline 43 & RB-76A & 1977 & 0.117 & 0.013 & 0.093 & 0.025 & 0.065 & 0.112 & 1975 & 0.135 & 0.047 & 1.0 & 5.0 & 52.6 \\
\hline 44 & RB-76B & 1977 & 0.091 & 0.229 & 0.035 & 0.537 & 0.012 & 0.701 & 1975 & 0.127 & 0.057 & 6.3 & 6.3 & 40.9 \\
\hline 57 & RB-77R & 1978 & 0.037 & 0.045 & 0.024 & 0.321 & 0.015 & 0.658 & 1976 & 0.146 & 0.026 & 6.9 & 6.9 & 55.4 \\
\hline
\end{tabular}


[Start year, first water year for statistical analysis; ft/yr, feet/year; Mod M-K, modified Mann-Kendall; p-value, probability value; M-K, Mann-Kendall; in/yr, inch per year; Years, years of water-level record; $<$, less than; --, not applicable; Up, number of statistically significant upward trends, Down, number of statistically significant downward trends. Statistically significant upward trends (positive Sen's slope with p-value less than or equal to 0.10 ) are noted with bold-face font and statistically significant downward trends (negative Sen's slope) are noted with italics]

\begin{tabular}{|c|c|c|c|c|c|c|c|c|c|c|c|c|c|c|}
\hline \multirow[t]{2}{*}{$\begin{array}{c}\text { Map } \\
\text { number }\end{array}$} & \multirow[t]{2}{*}{$\begin{array}{c}\text { Well } \\
\text { number }\end{array}$} & \multirow[t]{2}{*}{$\begin{array}{l}\text { Start } \\
\text { year }\end{array}$} & \multicolumn{2}{|c|}{$\begin{array}{c}\text { Annual minimum water } \\
\text { level }\end{array}$} & \multicolumn{2}{|c|}{$\begin{array}{c}\text { Annual median water } \\
\text { level }\end{array}$} & \multicolumn{2}{|c|}{$\begin{array}{c}\text { Annual maximum water } \\
\text { level }\end{array}$} & \multirow[t]{2}{*}{$\begin{array}{l}\text { Start } \\
\text { year }\end{array}$} & \multicolumn{2}{|c|}{$\begin{array}{l}\text { Annual total } \\
\text { precipitation }\end{array}$} & \multicolumn{3}{|c|}{$\begin{array}{l}\text { Licensed groundwater } \\
\text { withdrawals, in cubic feet } \\
\text { per second, within specified } \\
\text { radius of well, in miles }\end{array}$} \\
\hline & & & $\begin{array}{c}\text { Sen's Slope } \\
\text { (ft/yr) }\end{array}$ & $\begin{array}{c}\text { Mod M-K } \\
p \text {-value }\end{array}$ & $\begin{array}{c}\text { Sen's Slope } \\
\text { (ft/yr) }\end{array}$ & $\begin{array}{c}\text { Mod M-K } \\
p \text {-value }\end{array}$ & $\begin{array}{c}\text { Sen's Slope } \\
\text { (ft/yr) }\end{array}$ & $\begin{array}{c}\text { Mod M-K } \\
p \text {-value }\end{array}$ & & $\begin{array}{c}\text { Sen's Slope } \\
\text { (in/yr) }\end{array}$ & $\begin{array}{c}\text { M-K } \\
p \text {-value }\end{array}$ & 0.5 & 1.0 & 5.0 \\
\hline \multicolumn{15}{|c|}{ Observation wells monitoring Coteau Lakes aquifer system-Continued } \\
\hline 58 & RB-77S & 1978 & 0.040 & 0.013 & $\mathbf{0 . 0 3 3}$ & 0.005 & 0.027 & 0.006 & 1976 & 0.122 & 0.099 & 2.2 & 2.2 & 68.5 \\
\hline 59 & RB-77T & 1978 & 0.045 & 0.383 & 0.074 & 0.209 & 0.057 & 0.222 & 1976 & 0.133 & 0.059 & 5.8 & 11.7 & 44.9 \\
\hline 65 & RB-81C & 1982 & -0.058 & 0.004 & -0.062 & 0.002 & -0.056 & 0.001 & 1980 & 0.160 & 0.008 & 0.0 & 2.9 & 28.8 \\
\hline 66 & RB-81D & 1982 & 0.122 & 0.086 & 0.101 & 0.034 & 0.100 & 0.205 & 1980 & 0.137 & 0.097 & 0.0 & 0.0 & 33.8 \\
\hline 67 & RB-82B & 1982 & 0.000 & 0.955 & 0.003 & 0.895 & 0.000 & 0.936 & 1980 & 0.147 & 0.029 & 0.0 & 1.8 & 61.8 \\
\hline \multirow{3}{*}{\multicolumn{2}{|c|}{$\begin{array}{c}\text { Totals for trend } \\
\text { analyses }\end{array}$}} & Up & 6 & -- & 6 & -- & 4 & -- & -- & 11 & & -- & -- & -- \\
\hline & & Down & 1 & -- & 1 & -- & 1 & -- & -- & 0 & & -- & -- & -- \\
\hline & & No trend & 4 & -- & 4 & -- & 6 & -- & -- & 0 & & -- & -- & -- \\
\hline \multicolumn{15}{|c|}{ Observation wells monitoring Veblen aquifer system } \\
\hline 38 & ML-69A & 1970 & 0.511 & 0.001 & 0.528 & 0.001 & 0.545 & $<0.001$ & 1968 & 0.134 & 0.003 & 0.2 & 0.2 & 3.4 \\
\hline 39 & ML-70A & 1977 & 0.720 & $<0.001$ & 0.721 & $<0.001$ & 0.722 & $<0.001$ & 1975 & 0.155 & 0.018 & 0.0 & 0.0 & 0.2 \\
\hline 40 & ML-70B & 1977 & 0.843 & $<0.001$ & 0.853 & $<0.001$ & 0.859 & $<0.001$ & 1975 & 0.152 & 0.017 & 0.0 & 0.0 & 0.2 \\
\hline 52 & RB-77J & 1978 & 0.580 & 0.002 & 0.596 & 0.003 & 0.626 & 0.002 & 1976 & 0.181 & 0.013 & 0.0 & 0.0 & $<0.1$ \\
\hline 61 & RB-79B & 1980 & 0.084 & 0.083 & 0.100 & 0.019 & 0.107 & 0.035 & 1978 & 0.196 & 0.013 & 0.0 & 0.0 & 0.3 \\
\hline 62 & RB-79C & 1980 & 0.131 & 0.053 & 0.117 & 0.175 & 0.101 & 0.025 & 1978 & 0.164 & 0.014 & 0.4 & 2.0 & 3.3 \\
\hline 63 & RB-79D & 1980 & 0.010 & 0.703 & 0.021 & 0.570 & 0.050 & 0.205 & 1978 & 0.168 & 0.023 & 0.0 & 0.0 & 3.3 \\
\hline 64 & RB-81A & 1981 & 0.676 & $<0.001$ & 0.709 & $<0.001$ & 0.729 & $<0.001$ & 1979 & 0.232 & 0.003 & 0.0 & 0.0 & 0.0 \\
\hline 71 & RB-\#07 & 1981 & 0.004 & 0.858 & -0.018 & 0.655 & -0.030 & 0.479 & 1979 & 0.183 & 0.010 & 0.0 & 0.0 & 5.6 \\
\hline 73 & RB-\#11 & 1981 & 0.250 & $<0.001$ & 0.251 & $<0.001$ & 0.257 & $<0.001$ & 1979 & 0.178 & 0.011 & 0.0 & 0.0 & 3.3 \\
\hline 74 & RB-\#12 & 1981 & 0.224 & $<0.001$ & 0.220 & $<0.001$ & 0.215 & $<0.001$ & 1979 & 0.193 & 0.009 & 1.3 & 1.3 & 4.9 \\
\hline 75 & RB-\#19 & 1982 & 0.244 & $<0.001$ & 0.250 & $<0.001$ & 0.243 & $<0.001$ & 1980 & 0.205 & 0.014 & 0.0 & 1.3 & 3.3 \\
\hline 76 & RB-\#20 & 1981 & 0.251 & $<0.001$ & 0.254 & $<0.001$ & 0.247 & $<0.001$ & 1979 & 0.196 & 0.010 & 0.0 & 2.0 & 3.3 \\
\hline \multirow{3}{*}{\multicolumn{2}{|c|}{$\begin{array}{c}\text { Totals for trend } \\
\text { analyses }\end{array}$}} & $\mathbf{U p}$ & 11 & -- & 10 & -- & 11 & -- & -- & 13 & -- & -- & -- & -- \\
\hline & & Down & 0 & -- & 0 & -- & 0 & -- & -- & 0 & -- & -- & -- & -- \\
\hline & & No trend & 2 & -- & 3 & -- & 2 & -- & -- & 0 & -- & -- & -- & -- \\
\hline
\end{tabular}



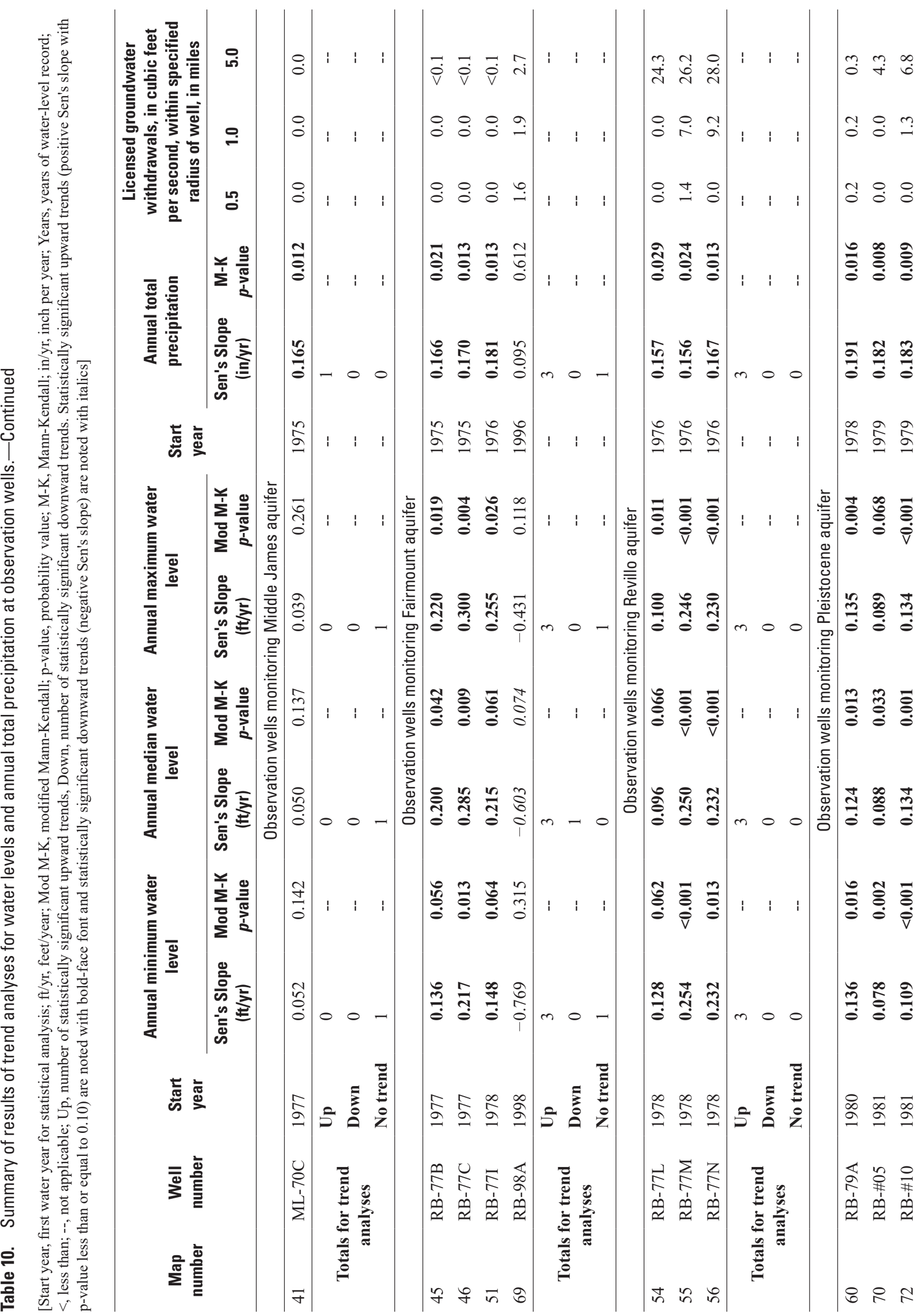
[Start year, first water year for statistical analysis; ft/yr, feet/year; Mod M-K, modified Mann-Kendall; p-value, probability value; M-K, Mann-Kendall; in/yr, inch per year; Years, years of water-level record; $<$, less than; --, not applicable; Up, number of statistically significant upward trends, Down, number of statistically significant downward trends. Statistically significant upward trends (positive Sen's slope with p-value less than or equal to 0.10 ) are noted with bold-face font and statistically significant downward trends (negative Sen's slope) are noted with italics]

\begin{tabular}{|c|c|c|c|c|c|c|c|c|c|c|c|c|c|c|}
\hline \multirow[t]{2}{*}{$\begin{array}{c}\text { Map } \\
\text { number }\end{array}$} & \multirow[t]{2}{*}{$\begin{array}{c}\text { Well } \\
\text { number }\end{array}$} & \multirow[t]{2}{*}{$\begin{array}{l}\text { Start } \\
\text { year }\end{array}$} & \multicolumn{2}{|c|}{$\begin{array}{c}\text { Annual minimum water } \\
\text { level }\end{array}$} & \multicolumn{2}{|c|}{$\begin{array}{c}\text { Annual median water } \\
\text { level }\end{array}$} & \multicolumn{2}{|c|}{$\begin{array}{c}\text { Annual maximum water } \\
\text { level }\end{array}$} & \multirow[t]{2}{*}{$\begin{array}{l}\text { Start } \\
\text { year }\end{array}$} & \multicolumn{2}{|c|}{$\begin{array}{l}\text { Annual total } \\
\text { precipitation }\end{array}$} & \multicolumn{3}{|c|}{$\begin{array}{l}\text { Licensed groundwater } \\
\text { withdrawals, in cubic feet } \\
\text { per second, within specified } \\
\text { radius of well, in miles }\end{array}$} \\
\hline & & & $\begin{array}{c}\text { Sen's Slope } \\
\text { (ft/yr) }\end{array}$ & $\begin{array}{c}\text { Mod M-K } \\
p \text {-value }\end{array}$ & $\begin{array}{c}\text { Sen's Slope } \\
\text { (ft/yr) }\end{array}$ & $\begin{array}{c}\text { Mod M-K } \\
p \text {-value }\end{array}$ & $\begin{array}{c}\text { Sen's Slope } \\
\text { (ft/yr) }\end{array}$ & $\begin{array}{c}\text { Mod M-K } \\
p \text {-value }\end{array}$ & & $\begin{array}{l}\text { Sen's Slope } \\
\text { (in/yr) }\end{array}$ & $\begin{array}{c}\text { M-K } \\
p \text {-value }\end{array}$ & 0.5 & 1.0 & 5.0 \\
\hline \multicolumn{15}{|c|}{ Observation wells monitoring Pleistocene aquifer-Continued } \\
\hline \multirow{3}{*}{\multicolumn{2}{|c|}{$\begin{array}{c}\text { Totals for trend } \\
\text { analyses }\end{array}$}} & Up & 3 & -- & 3 & -- & 2 & -- & -- & 3 & -- & -- & -- & -- \\
\hline & & Down & 0 & -- & 0 & -- & 0 & -- & -- & 0 & -- & -- & -- & -- \\
\hline & & No trend & 0 & -- & 0 & -- & 1 & -- & -- & 0 & -- & -- & -- & -- \\
\hline \multicolumn{15}{|c|}{ Observation wells monitoring Rosholt aquifer } \\
\hline 47 & RB-77D & 1978 & 0.219 & 0.020 & 0.218 & 0.030 & 0.200 & 0.043 & 1976 & 0.194 & 0.006 & 0.0 & 1.6 & 2.7 \\
\hline 48 & RB-77E & 1978 & 0.302 & 0.060 & 0.312 & 0.032 & 0.275 & 0.043 & 1976 & 0.181 & 0.009 & $<0.1$ & $<0.1$ & 2.7 \\
\hline 49 & $\mathrm{RB}-77 \mathrm{~F}$ & 1978 & 0.362 & $<0.001$ & 0.459 & $<0.001$ & 0.533 & $<0.001$ & 1976 & 0.176 & 0.016 & 0.0 & 0.0 & 1.6 \\
\hline 50 & RB-77G & 1978 & 0.261 & 0.004 & 0.210 & 0.003 & 0.175 & 0.002 & 1976 & 0.187 & 0.009 & 0.0 & 0.0 & 2.7 \\
\hline 53 & RB-77K & 1978 & 0.606 & 0.001 & 0.605 & 0.001 & 0.646 & 0.001 & 1976 & 0.180 & 0.011 & 0.0 & 0.0 & 0.0 \\
\hline \multirow{3}{*}{\multicolumn{2}{|c|}{$\begin{array}{c}\text { Totals for trend } \\
\text { analyses }\end{array}$}} & Up & 5 & -- & 5 & -- & 5 & -- & -- & 5 & -- & -- & -- & -- \\
\hline & & Down & 0 & -- & 0 & -- & 0 & -- & -- & 0 & -- & -- & -- & -- \\
\hline & & No trend & 0 & -- & 0 & -- & 0 & -- & -- & 0 & -- & -- & -- & -- \\
\hline
\end{tabular}




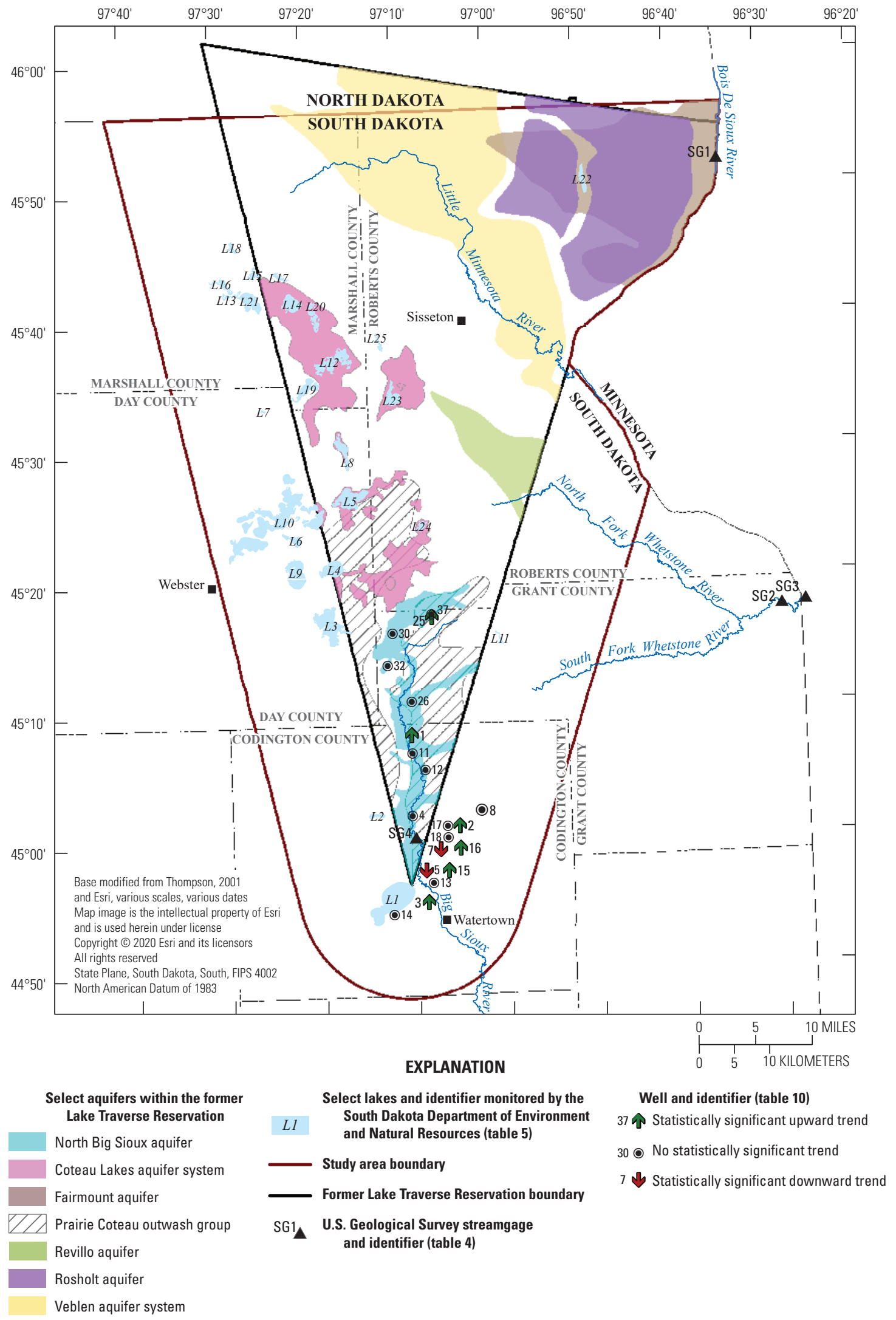

Figure 15. Wells completed in the North Big Sioux aquifer with statistically significant trends for at least one water-level parameter. 
more than 15 years (table 5). Twin Lake (lake L11) is closest for wells GT-57A, GT-76A, and GT-82A, and Bitter Lake (lake L3) is closest for wells GT-77B and GT-77D. Waubay (North) Lake (L10) was preferentially selected over Lake Kampeska (L1) for well GT-77D because of the strong correlation (table 8) and to provide a better visual fit with the well data. Lake Kampeska was preferentially selected for the other four wells because of its hydraulic connection with the North Big Sioux aquifer (figs. 1 and 15).

Analyses for the 16 wells completed in the Prairie Coteau outwash group are provided in figures 1.21 through 1.36. Well CD-76A is one of four wells with significant downward trends for at least one water-level parameter (table 10, fig. 16). This well has cumulative withdrawals of $28.4 \mathrm{ft} 3 / \mathrm{s}$ within a radius of $5 \mathrm{mi}$, which is the third smallest withdrawal rate within $5 \mathrm{mi}$ for any of the Prairie Coteau outwash group wells. Three of the five wells with significant upward trends for at least one water-level parameter have larger withdrawals within $5 \mathrm{mi}$ (table 10). Well DA-78H has cumulative withdrawals of $14.0 \mathrm{ft}^{3} / \mathrm{s}$ within a radius of $5 \mathrm{mi}$, which is the smallest withdrawal rate within $5 \mathrm{mi}$ for any of the Prairie Coteau outwash group wells. The next smallest withdrawal rates within $5 \mathrm{mi}$ are $27.6 \mathrm{ft} 3 / \mathrm{s}$ for well DA-78E, which has significant upward trends for all three water-level parameters, and $28.4 \mathrm{ft} 3 / \mathrm{s}$ for well CD-76A, which has a has a significant downward trend for the time series of the annual minimum water level. Withdrawals rates within $1.0 \mathrm{mi}$ for these two wells are 1.1 and $1.8 \mathrm{ft} 3 / \mathrm{s}$, respectively. In general, collective consideration of the licensed groundwater withdrawal data implies that trends in water levels likely are affected less by proximal withdrawals than by other factors. The nonsignificant trends could indicate that Prairie Coteau outwash group is losing or has withdrawals equal to recharge, however, additional information would be needed to make this determination.

Five different lakes, including Kampeska, Bitter, Waubay, Twin, and Hurricane Lakes (table 8), were selected for use in the plots for wells completed in the Prairie Coteau outwash group that are presented in figures 1.21 through 1.36, which reflect several somewhat distinctive patterns associated with the groundwater levels. Lake Kampeska was selected for wells CD-76A, CD-76D, and CD-77A, all of which show distinctive seasonal drawdown (figs. 1.21, 1.22, and 1.23) associated with proximal groundwater withdrawals and two of which have a significant downward trend for the time series of the annual minimum water level (table 10). Bitter Lake was selected for wells DA-78E, DA-78F, DA-78H, and GT-77C (figs 1.24, $1.25,1.26,1.31$ ), and Waubay (North) Lake was selected for well DA-82C (fig. 1.27), all of which show distinctively large increases in groundwater levels that have strong resemblance to lake levels for these two lakes. Twin or Hurricane Lakes (lakes L11 and L24, respectively) were selected for all of the other Prairie Coteau outwash group wells in Grant County.

Analyses for the 11 wells completed in the Coteau Lakes aquifer system are provided in figures 1.37 through 1.47. Well RB-81C, which is the only well with significant downward trends for any of the three water-level parameters (table 10, fig. 17), has withdrawals of $28.8 \mathrm{ft} 3 / \mathrm{s}$ within a radius of $5 \mathrm{mi}$. Five of the seven wells with significant upward trends for at least one water-level parameter have larger withdrawals within $5 \mathrm{mi}$.

Five different lakes, including Waubay (North), Buffalo (South), Hurricane, Clear, and Enemy Swim Lakes (table 8), were selected for use in the plots for wells completed in the Coteau Lakes aquifer that are presented in figures 1.37 through 1.47. Clear Lake, which was selected for well RB-81C, has a somewhat strong correlation coefficient of 0.802 for the time series of the annual maximum water level. However, that strong correlation likely is coincidental because (1) the correlation for the time series of the annual median water level is inverse $(-0.405),(2)$ the fit of the well- and lake-level plot is visually quite poor, and (3) well RB-81C is located about $20 \mathrm{mi}$ south of Clear Lake (lake L14 on fig. 17). Somewhat strong correlations with lake levels for the other 10 wells likely are not entirely coincidental because (1) the wells are located somewhat close to the selected lakes, all of which are located within or near mapped outcrops of the Coteau Lakes aquifer system; and (2) fits of the well- and lake-level plots are visually relatively good. This inference does not necessarily imply direct hydraulic connections with the selected lakes but may instead imply connections with other proximal lakes or water bodies with similar responses to climatic drivers.

Analyses for the 13 wells completed in the Veblen aquifer are provided in figures 1.48 through 1.60. Eleven wells have significant upward trends for at least two of the three waterlevel parameters and two wells do not have significant trends for any of the water-level parameters (table 10, fig. 18). Wells RB-77J and RB-81A have withdrawals of less than $0.1 \mathrm{ft} 3 / \mathrm{s}$ within a 5 -mi radius. Cumulative withdrawals within $5 \mathrm{mi}$ range from 0.2 to $5.6 \mathrm{ft}^{3} / \mathrm{s}$ for the other 11 wells.

Five different lakes, including Bitter, Waubay (North), Clear, Drywood (North), and Cottonwood (North) Lakes (table 8), were selected for use in the plots for wells completed in the Veblen aquifer that are presented in figures 1.48 through 1.60. Bitter Lake or Waubay (North) Lake was selected for use in the plots for five wells with especially large increases in groundwater levels and especially strong correlations with both lakes. Of the 10 correlation coefficients for these five wells, 9 were 0.963 or greater. Drywood (North) Lake (lake L23) was selected for use in the plots for five wells with especially large correlation coefficients. Of the 10 correlation coefficients for these five wells, 8 were 0.888 or greater. Hydraulic connections with any of these selected lakes may be unlikely because (1) Drywood (North) Lake (lake L23) is more than $10 \mathrm{mi}$ from the nearest of the wells considered (fig. 18) and Bitter and Waubay (North) Lakes (lakes L3 and L10, respectively) are more than $30 \mathrm{mi}$ from the nearest of the wells considered, and (2) none of these lakes are within or near the mapped outcrop of the Veblen aquifer.

Analyses for the single well completed in the Middle James aquifer are provided in figure 1.61. Trends are not significant for any of three water-level parameters (table 10), and a trend map is not provided for this single well. There are 


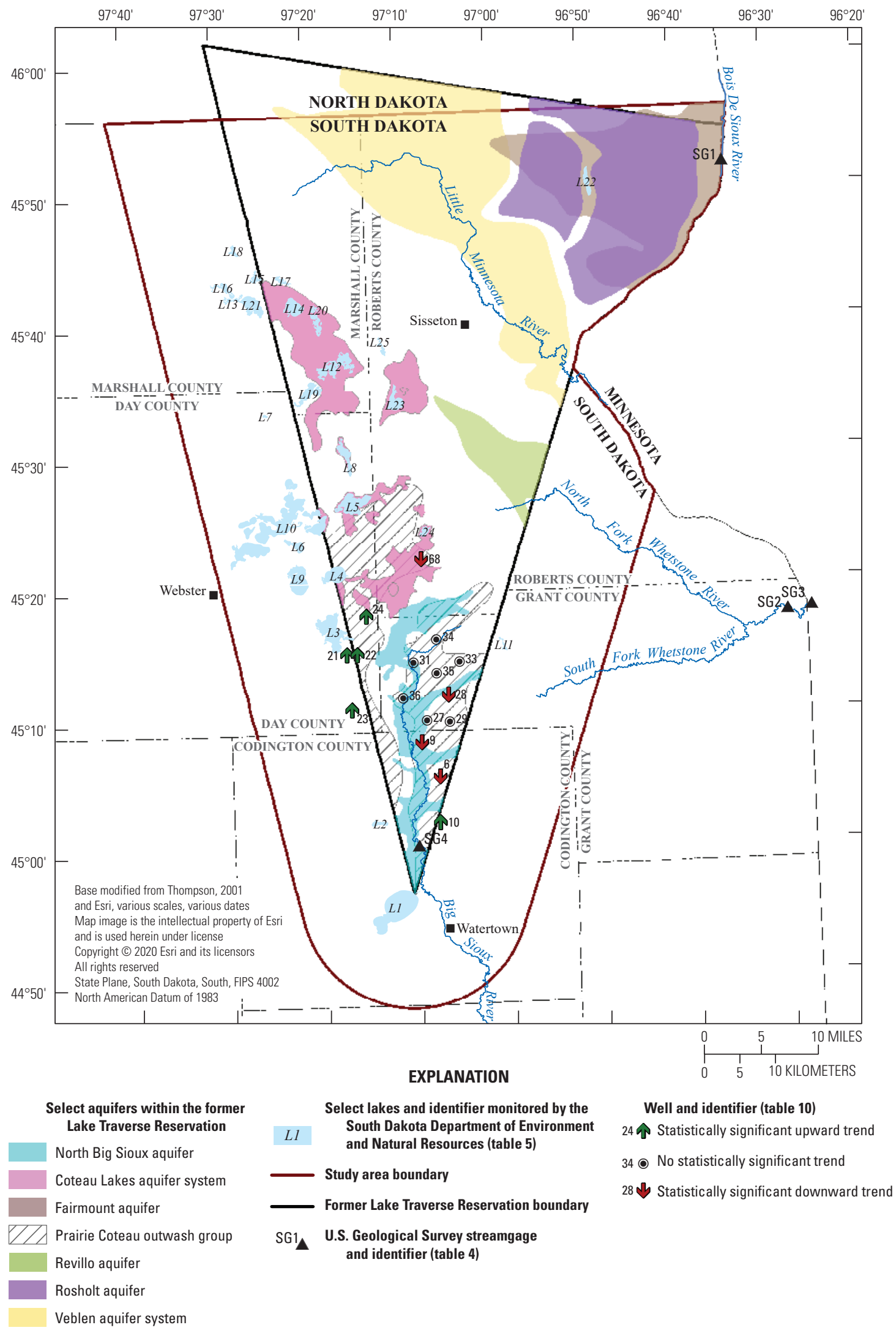

Figure 16. Wells completed in the Prairie Coteau outwash group with statistically significant trends for at least one water-level parameter. 


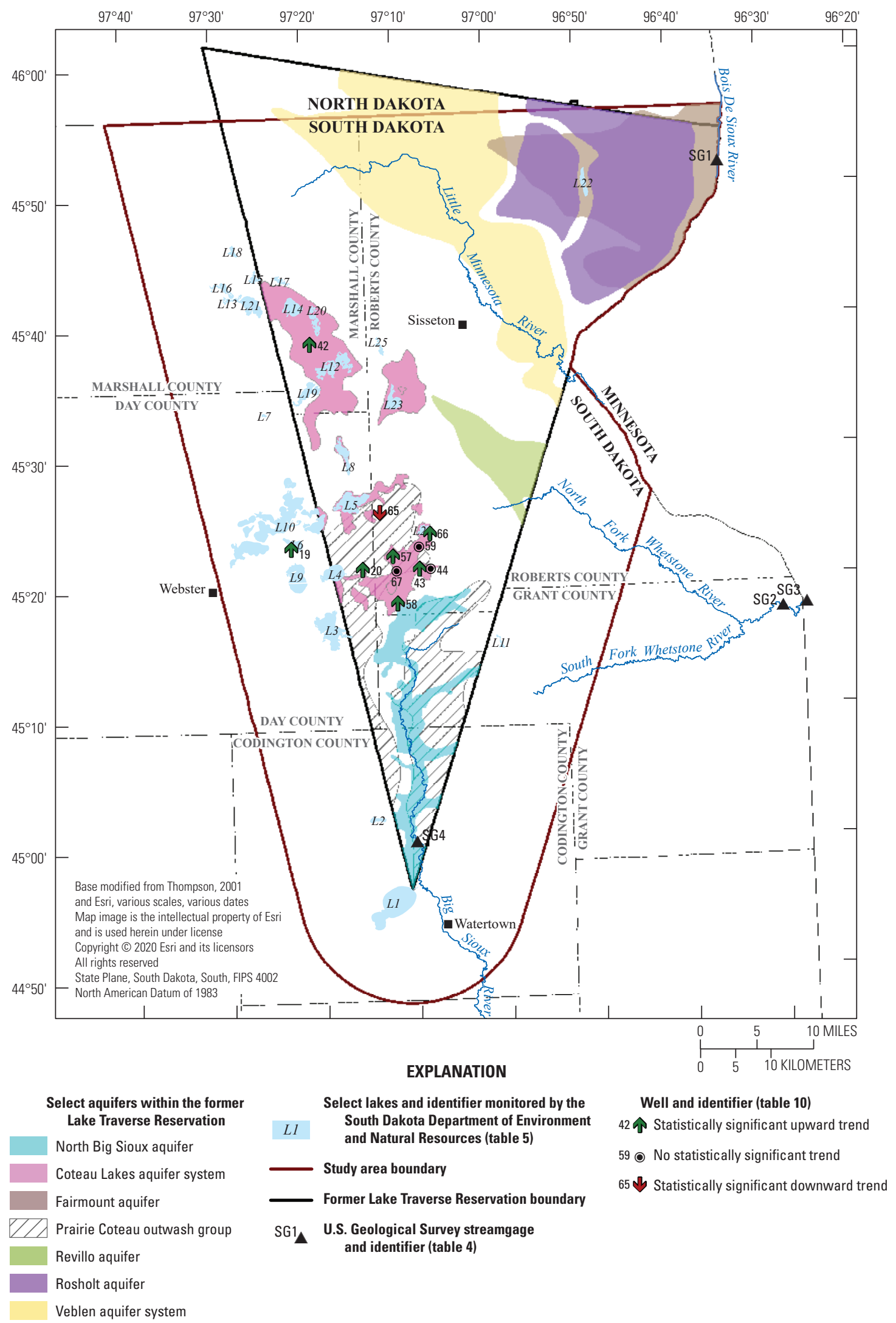

Figure 17. Wells completed in the Coteau Lakes aquifer system with statistically significant trends for at least one water-level parameter. 

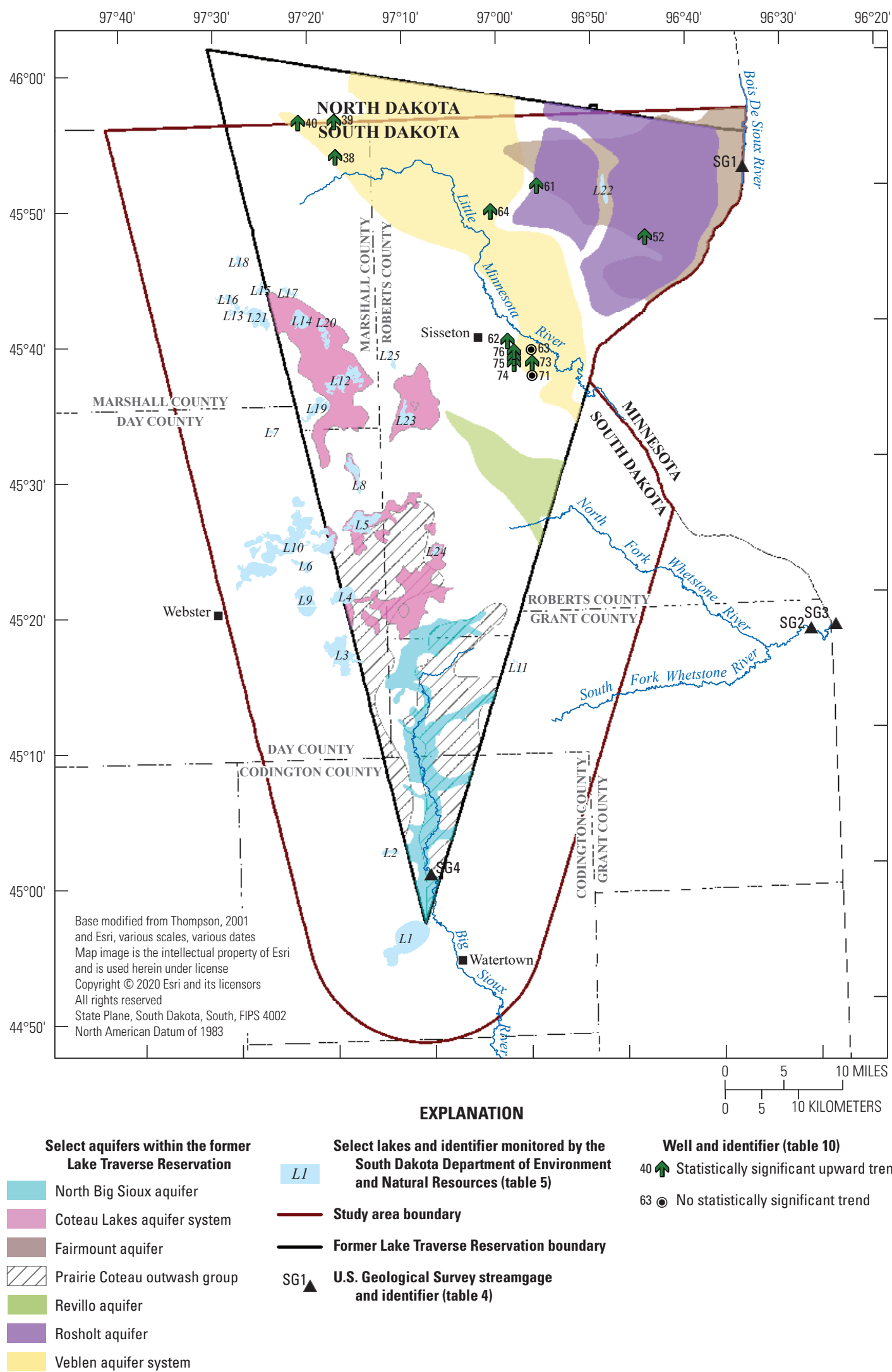

Well and identifier (table 10) $40 \uparrow$ Statistically significant upward trend 63 No statistically significant trend

Figure 18. Wells completed in the Veblen aquifer with statistically significant trends for at least one water-level parameter. 
no withdrawals within $5 \mathrm{mi}$ of the single well. Buffalo (South) Lake, which was selected for use in the plot, is located about 20 mi south-southeast of the well (fig. 1).

Analyses for the four wells completed in the Fairmount aquifer are provided in figures 1.62 through 1.65 . Well RB$98 \mathrm{~A}$, which has cumulative withdrawals of $2.7 \mathrm{ft} 3 / \mathrm{s}$ within a 5-mi radius, has a significant downward trend for the time series of the annual median water level (table 10, fig. 19). The other three wells have withdrawals of less than $0.1 \mathrm{ft} 3 / \mathrm{s}$ within $5 \mathrm{mi}$ and have significant upward trends for all three waterlevel parameters. However, the water-level plots for all three of these wells show visual evidence of drawdown of about $15 \mathrm{ft}$ or more since about 2014.

All four of the Fairmount aquifer wells are located close to Cottonwood (North) Lake (lake L22) in the northeast part of the study area (fig. 19). However, Buffalo (South) Lake (lake L12) was selected for plotting with three of the four wells because of a better visual fit with the groundwater data, especially for the data from the early 1980s to the early 1990s.

Analyses for three wells completed in the Revillo aquifer are provided in figures 1.66 through 1.68. All three wells have significant upward trends for all three water-level parameters (table 10, fig. 20). Cumulative withdrawals within $5 \mathrm{mi}$ range from 24.3 to $28.0 \mathrm{ft}^{3} / \mathrm{s}$ for these wells. All three of the Revillo aquifer wells are located about 12 to 14 mi east of Hurricane Lake (lake L24) in the east-central part of the study area (fig. 20). However, Clear Lake (lake L14) was selected for plotting for all three of the wells (table 8 ) because of a better visual fit with the groundwater data.

Analyses for three wells completed in the Pleistocene aquifer are provided in figures 1.69 through 1.71. All three wells have significant upward trends for all three water-level parameters (table 10). Cumulative withdrawals within $5 \mathrm{mi}$ range from 0.3 to $6.8 \mathrm{ft} 3 / \mathrm{s}$ for these wells. A trend map is not provided because the extent of the Pleistocene outwash group has not been mapped; however, well RB-79A (map number 60) is located near the western extent of the Rosholt aquifer in the northeastern part of the study area (fig. 1) and wells RB-\#05 and RB-\#10 (map numbers 70 and 72) are located about 15 mi south of well RB-79A. Drywood (North) Lake is the nearest lake for wells RB-\#05 and RB-\#10 (lake L24) and was selected for plotting for these two lakes. Buffalo (South) Lake (lake L12) was selected for well RB-79A because of a better visual fit.
Analyses for five wells completed in the Rosholt aquifer are provided in figures 1.72 through 1.76. All five wells have significant upward trends for all three water-level parameters (table 10, fig. 21). Cumulative withdrawals within $5 \mathrm{mi}$ range from 0.0 to $2.7 \mathrm{ft} 3 / \mathrm{s}$ for these wells. Waubay (North) Lake was selected for plotting with well RB-77K because of a strong correlation (table 8) and good visual fit. Buffalo (South) Lake was selected for the other four Rosholt aquifer wells because of somewhat strong correlations and good visual fits.

Overall, trends in groundwater levels in observation wells in the study area are predominantly upward, with 43 of 76 wells having significant upward trends for at least one of the three water-level parameters and only 8 wells having significant downward trends for at least one parameter. The upward groundwater trends are driven by predominantly upward precipitation trends, with 43 observation wells (not all the same wells) also having significant upward trends and no wells having significant downward trends. Significant upward precipitation trends were detected for only two of the eight wells with significant downward groundwater trends. Groundwater levels in some observation wells likely are also substantially affected by interactions with surface water, especially with lakes. Water levels in many area lakes also have increased in response to the wet conditions of the early 1990s and have maintained high water levels ever since. It is recognized that in many cases lakes that were selected for plotting with groundwater hydrographs likely are not hydraulically connected with a groundwater system or aquifer associated with an individual well; however, interactions are plausible for numerous other lakes for which water-level records are not available. In addition, changes in lake levels, regardless of drainage basin, may be indicative of changes in groundwater levels.

To further characterize changes in groundwater levels additional information, such as recharge, groundwater-surface water interactions, and actual water use, would need to be quantified. Also, to enhance the spatial trend analysis so areas of unsustainable use can be identified, more observation wells are necessary in the study area, especially for aquifers, such as the Fairmount, the Middle James, the Revillo, and the Rosholt that only have $1-5$ observation wells in the study area. 


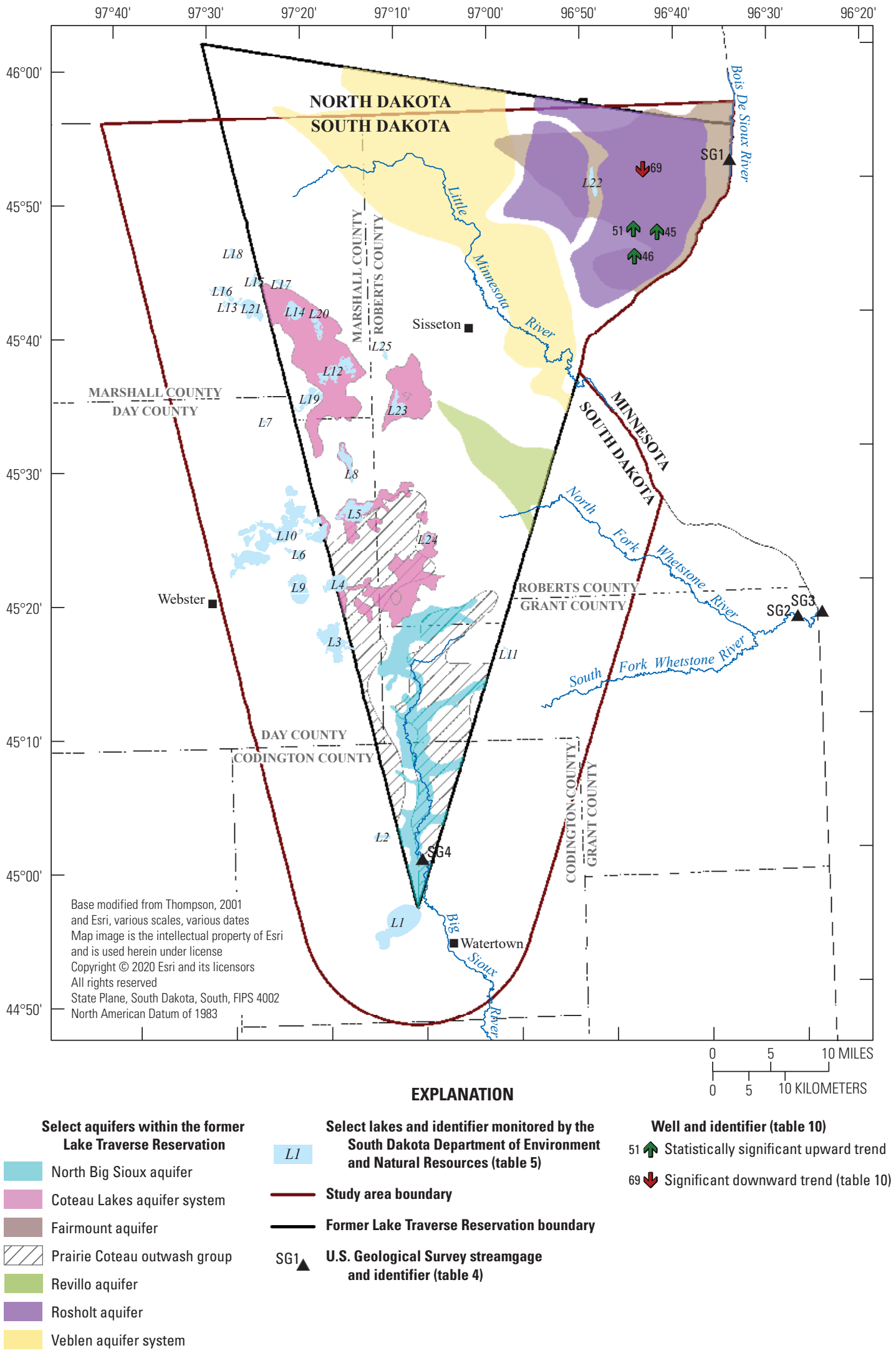

Figure 19. Wells completed in the Fairmount aquifer with statistically significant trends for at least one water-level parameter. 


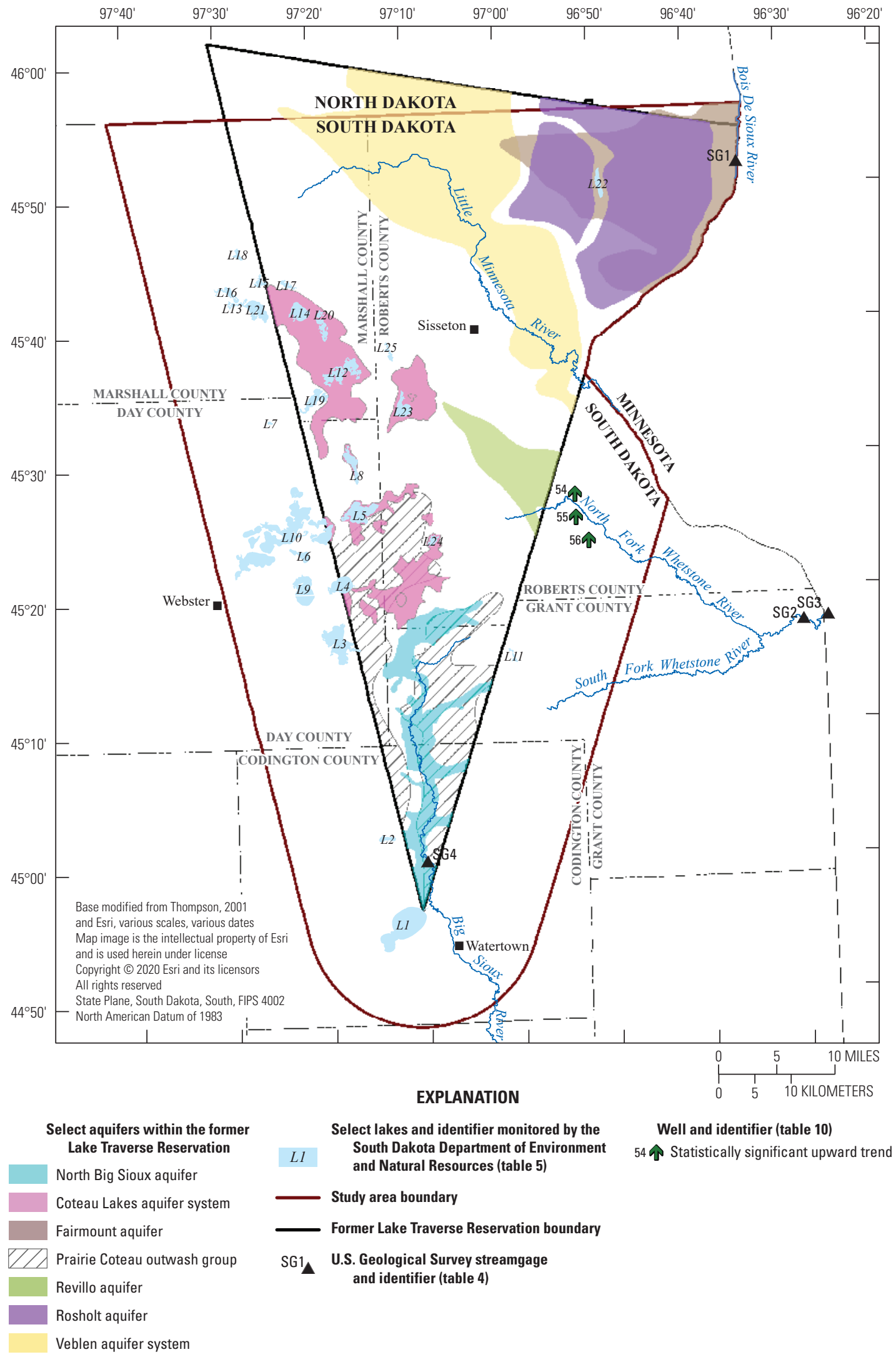

Figure 20. Wells completed in the Revillo aquifer with statistically significant trends for at least one water-level parameter. 


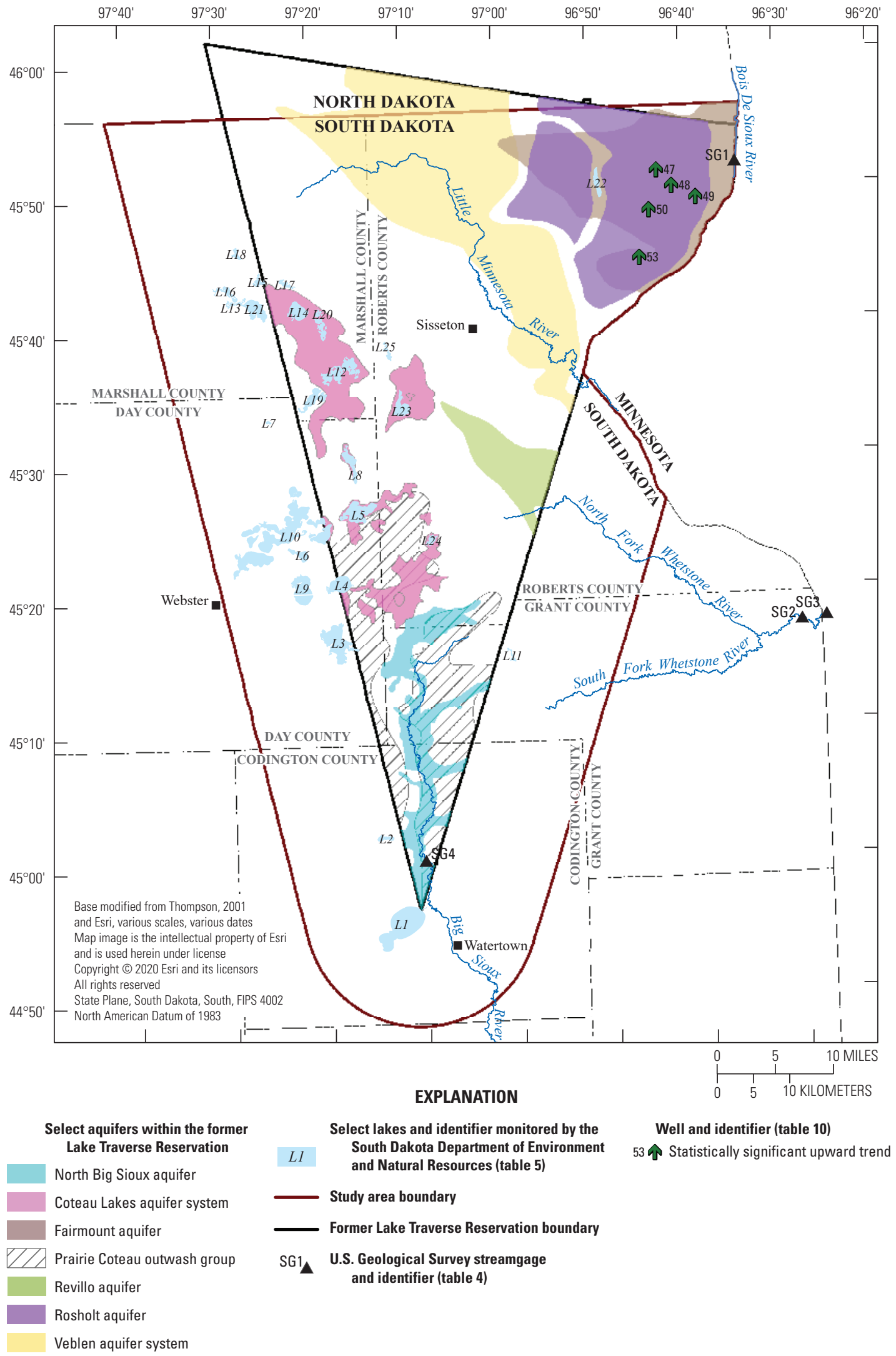

Figure 21. Wells completed in the Rosholt aquifer with statistically significant trends for at least one water-level parameter. 


\section{Summary}

The U.S. Geological Survey, in cooperation with the Sisseton Wahpeton Oyate, completed a study to characterize water-level fluctuations in observation wells and to identify driving factors that affect water levels in and near the historical 1867 boundary of the Lake Traverse Indian Reservation. The study investigates concerns regarding potential effects of groundwater withdrawals and climate conditions on groundwater levels within an area that includes the historical boundary of the reservation and a surrounding area that extends 10 miles (mi) in all directions within South Dakota. Driving factors considered include climate conditions (precipitation, minimum temperature, maximum temperature), interactions with surface water, and groundwater withdrawals. Trends over time are analyzed for water-level records during 1957-2017 for 76 observation wells in the study area and for estimated precipitation at the well locations. Interactions with surface water (rivers and lakes) and groundwater withdrawals within a 5-mi radius of each observation well also are qualitatively considered as driving factors.

Analyses primarily involved (1) analysis of trends over time for measured water levels in observation wells and for estimated precipitation at each observation well, (2) qualitative consideration of interactions between groundwater and surface water, and (3) qualitative consideration of effects of groundwater withdrawals on groundwater levels. Water-level records were analyzed for 76 observation wells monitored by the South Dakota Department of Environment and Natural Resources, with the earliest records beginning in water year (WY) 1957-61. All climate data considered (primarily annual precipitation) were obtained from the Parameter-elevation Regressions on Independent Slopes Model (PRISM).

Many of the statistical analyses involved trend testing in annual time steps for statistical significance and trend magnitude. Before trend testing, applicable datasets were tested for statistically significant short-term persistence (STP). In the absence of significant STP, statistical significance was determined using the standard Mann-Kendall test for probability values less than or equal to 0.10 (90-percent confidence level). However, a modified Mann-Kendall test was used for datasets where statistically significant STP was detected. Trend magnitudes were computed using the Sen's slope estimator.

Monthly PRISM data were aggregated to obtain annual and seasonal datasets for total precipitation, minimum air temperature $\left(T_{\min }\right)$, and maximum air temperature $\left(T_{\max }\right)$ for the study area and a surrounding buffer area. Trend tests for total precipitation, $T_{\min }$, and $T_{\max }$ were completed for annual and seasonal time series for WYs 1956-2017, which is about 2 years before the earliest available water-level measurements. Statistically significant upward trends were detected for annual precipitation and annual $T_{\min }$ for most of the study area and the surrounding buffer area. Statistically significant downward trends in $T_{\max }$ were detected for only a few 2.5 arcminute grid cells; however, the sparsity of the spatial coverage reduces confidence that these are true trends relative to the near completeness of the spatial coverage in upward trends for $T_{\text {min }}$. Spatial distributions of statistically significant trends in seasonal climate data were generally similar to the annual trends, but with substantial differences in the spatial density of the trends.

Estimates of annual total precipitation for the study area for three different time periods were examined in greater detail to obtain additional perspectives on precipitation patterns. Statistically significant upward trends were indicated for 1975-2017 and 1956-2017 but not for 1896-2017. The mean precipitation during 1975-2017 was 23.14 inches, which is greater than the means for 1956-2017 (22.58) and 1896-2017 (22.20) by 0.56 and 0.94 inch, respectively.

Potential interactions among water levels in observation wells and streamflow were examined through correlation analyses of the annual median water level for each of the 76 observation wells versus the annual mean streamflow for each of four area streamgages. The strongest correlations for 13 of the 20 wells completed in the North Big Sioux aquifer are with the Big Sioux River. The strongest correlations also are with the Big Sioux River for 10 of the 16 wells completed in the Prairie Coteau outwash group. For 8 of the 11 wells completed in the Coteau Lakes aquifer system, the strongest correlations are with the Whetstone River (1 well) and Minnesota River ( 7 wells). For 10 of the 13 wells completed in the Veblen aquifer and for 3 of the 4 wells completed in the Fairmount aquifer, the strongest correlations are with either the Bois de Sioux River or Minnesota River. The strongest correlations for all five wells completed in the Rosholt aquifer are with the Bois de Sioux River.

Potential interactions among water levels in observation wells and lake levels were examined through correlation analyses involving 25 area lakes. Correlation coefficients were computed for the annual median and annual maximum water level for each observation wells versus annual median water level for each lake. The annual maximum groundwater levels were considered because the annual median values for many wells can be affected by drawdown from nearby withdrawals. The correlation coefficients were used as part of an approach for selecting a lake to be plotted in conjunction with precipitation and water-level data for each observation well. Water levels in many area lakes have increased in response to the wet conditions of the early 1990s and have maintained high water levels ever since. However, lake levels have not increased similarly for many other lakes for which water levels are controlled by spilling over a lake outlet. In many cases, groundwater levels in observation wells can have strong resemblance to water levels in one or more area lakes, and strong correlations among groundwater levels and lake levels are not entirely coincidental. However, it is recognized that in many other cases the selected lake likely is not hydraulically connected with a groundwater system or aquifer associated with an individual well, especially in cases of increasing distance between a lake and well. 
Groundwater trends for observation wells were analyzed for three separate water-level parameters (minimum, median, and maximum) because wells are measured sporadically, and data are biased towards more frequent measurements during periods of heaviest irrigation demand. Trends in the time series of annual precipitation (from PRISM) starting 2 years earlier than the associated water-level trend also were analyzed for the location of each individual observation well. Sen's slope and Mann-Kendall $p$-values were computed for the three water-level parameters and for the annual precipitation time series. Graphs showing results of trend analyses for each observation well also showed changes over time in the sum of groundwater withdrawals within six specified radii $(0.5,1,2$, 3,4 , and $5 \mathrm{mi}$ ) of each well as a qualitative indicator of proximal groundwater demand.

Of all 76 wells considered, 43 wells have statistically significant upward trends for at least one of the three waterlevel parameters, 8 wells have significant downward trends for at least one parameter, and 25 wells do not have any significant trends. Significant upward trends in annual precipitation are indicated for 43 wells and nonsignificant trends are indicated for 33 wells. Most of the wells with nonsignificant precipitation trends are completed in the Big Sioux aquifer or Prairie Coteau outwash group and are located in Codington, Day, or Grant Counties in the southern part of the study area where precipitation trends for 1957-2017 are predominantly nonsignificant.

Of 20 wells completed in the North Big Sioux aquifer, only one has a significant upward trend for precipitation. However, four wells have significant upward trends for all three water-level parameters and two wells have significant upward trends for at least one parameter. Two wells completed in the North Big Sioux aquifer have significant downward trends for all three water-level parameters. The two wells with significant downward trends for all three water-level parameters have withdrawals of 53.4 and 54.5 cubic feet per second $(\mathrm{ft} 3 / \mathrm{s})$ within $5 \mathrm{mi}$, respectively. All six wells with significant upward trends for at least one water-level parameter have licensed groundwater withdrawals totaling at least $39.5 \mathrm{ft} 3 / \mathrm{s}$ within 5 mi.

Well CD-76A is 1 of 11 wells completed in the Prairie Coteau outwash group and 1 of 4 wells with significant downward trends for at least one water-level parameter. This well has cumulative withdrawals of $28.4 \mathrm{ft} 3 / \mathrm{s}$ within a radius of $5 \mathrm{mi}$, which is the third smallest withdrawal rate within $5 \mathrm{mi}$ for any of the Prairie Coteau outwash group wells. Three of the five wells completed in the Prairie Coteau outwash group with significant upward trends for at least one water-level parameter have larger withdrawals within $5 \mathrm{mi}$.
Well RB-81C, which is 1 of 11 wells completed in the Coteau Lakes aquifer system, is the only well with significant downward trends for any of the three water-level parameters. This well has withdrawals of $28.8 \mathrm{ft} 3 / \mathrm{s}$ within a radius of $5 \mathrm{mi}$. Five of the seven wells with significant upward trends for at least one water-level parameter have larger withdrawals within $5 \mathrm{mi}$.

Of 13 wells completed in the Veblen aquifer, 11 wells have significant upward trends for at least two of the three water-level parameters. Two wells do not have significant trends for any of the water-level parameters.

Well RB-98A, which is one of four wells completed in the Fairmount aquifer and has withdrawals of $2.7 \mathrm{ft} 3 / \mathrm{s}$ within a 5-mi radius, is the only well with significant downward trends for any of the three water-level parameters. The other three wells have withdrawals of less than $0.1 \mathrm{ft} 3 / \mathrm{s}$ within $5 \mathrm{mi}$ and have significant upward trends for all three water-level parameters.

Trends in groundwater levels were analyzed for 12 other wells completed in the Middle James aquifer (1 well), Revillo aquifer ( 3 wells), Pleistocene aquifer ( 3 wells), and Rosholt aquifer ( 5 wells). Significant upward trends were detected for all three water-level parameters for all 12 wells except for the single well completed in the Middle James aquifer, for which significant trends were not detected for any of the three waterlevel parameters.

Overall, the results of the groundwater analyses indicated that water levels were driven by predominantly upward precipitation trends in the study area. The Coteau Lakes aquifer system, the Fairmount aquifer, the Revillo aquifer, the Rosholt aquifer, and the Veblen aquifer had observation wells with mostly significant upward trends in water levels. The North Big Sioux aquifer and the Prairie Coteau outwash group had mostly no significant trends in water levels, with a few significant upward and downward trends interspersed throughout the aquifer. These nonsignificant trends could indicate that the aquifer and outwash group are losing or have withdrawals equal to recharge, however, additional information would be needed to make this determination. To further characterize changes in groundwater levels additional information, such as recharge, groundwater-surface water interactions, and actual water use, would need to be quantified. Also, to enhance the spatial trend analysis so areas of unsustainable use could be identified, more observation wells would be necessary in the study area, especially for aquifers, such as the Fairmount, the Middle James, the Revillo, and the Rosholt that have only 1-5 observation wells in the study area. 


\section{References Cited}

Armstrong, C.A., 1982, Ground-water resources of Ransom and Sargent Counties, North Dakota: North Dakota Geological Survey Bulletin 69, Part III, 51 p. [Also available at https://www.swc.nd.gov/info_edu/reports_and publications/county_groundwater_studies/pdfs/Ransom Sargent_Part_III.pdf.]

Baker, C.H., and Paulson, Q.F., 1967, Geology and ground water resources of Richland County, North Dakota: North Dakota Geological Survey Bulletin 46, Part III, 45 p. [Also available at https://www.swc.nd.gov/info_edu/reports_and publications/county_groundwater_studies/pdfs/Richland_ Part_III.pdf.]

Bayazit, M., 2015, Nonstationarity of hydrological records and recent trends in trend analysis-A state-of-the-art review: Environmental Processes, v. 2, no. 3, p. 527-542. [Also available at https://doi.org/10.1007/s40710-015-0081-7.]

Carter, J.M., and Neitzert, K.M., 2008, Estimated use of water in South Dakota, 2005: U.S. Geological Survey Scientific Investigations Report 2008-5216,30 p. [Also available at https://doi.org/10.3133/sir20085216.]

Cleveland, W.S., and Devlin, S.J., 1988, Locally-weighted regression-An approach to regression analysis by local fitting: Journal of the American Statistical Association, v. 83, no. 403, p. 596-610. [Also available at https://doi.org/ 10.1080/01621459.1988.10478639.]

Cleveland, W.S., Grosse, E., and Shyu, W.M., 1992, Local regression models, chap. 8 of Chambers, J.M., and Hastie, T.J., eds., Statistical Models in S: Wadsworth \& Brooks/ Cole, accessed March 31, 2020, at https://www.taylorfr ancis.com/books/e/9780203738535/chapters/10.1201/ 9780203738535-8.

Cohn, T.A., and Lins, H.F., 2005, Nature's style - Naturally trendy: Geophysical Research Letters, v. 32, no. 23, 5 p. [Also available at https://doi.org/10.1029/2005GL024476.]

Daly, C., Gibson, W.P., Taylor, G.H., Johnson, G.L., and Pasteris, P., 2002, A knowledge-based approach to the statistical mapping of climate: Climate Research, v. 22, no. 2, p. 99-113. [Also available at https://doi.org/10.3354/ cr022099.]

Daly, C.D., Halbleib, M., Smith, J.I., Gibson, W.P., Doggett, M.K., Taylor, G.H., Curtis, J., and Pasteris, P.P., 2008, Physiographically sensitive mapping of climatological temperature and precipitation across the conterminous United States: International Journal of Climatology, v. 28, no. 15, p. 2031-2064. [Also available at https://doi.org/10.1002/ joc.1688.]
Daly, C., Neilson, R.P., and Phillips, D.L., 1994, A statisticaltopographic model for mapping climatological precipitation over mountainous terrain: Journal of Applied Meteorology, v. 33 , no. 2 , p. $140-158$.

Dieter, C.A., Linsey, K.S., Caldwell, R.R., Harris, M.A., Ivahnenko, T.I., Lovelace, J.K., Maupin, M.A., and Barber, N.L., 2018, Estimated use of water in the United States county-level data for 2015 (ver. 2.0, June 2018): U.S. Geological Survey data release, accessed October 21, 2020, at https://doi.org/10.5066/F7TB15V5.

Erickson, H.D., 1955, Artesian conditions in northeastern South Dakota: South Dakota Geological Survey Report of Investigations No. 77, 39 p. [Also available at $h$ ttp://cf.sddenr.net/publist/search_results_publist.cfm? column_name $=$ Authors\&input_box $=$ Erickson $\& \mathrm{R} 1=$ simple\&search=Search.]

Gibson, W., Daly, C., Kittel, T., Nychka, D., Johns, C., Rosebloom, N., McNab, A., and Taylor, G., 2002, Development of a 103-year high-resolution climate data set for the conterminous United States: AMS Conference on Applied Climatology, Portland, Oreg., May 13-16, 2002, p. 181-183, accessed October 31, 2019, at https://ams.c onfex.com/ams/13ac10av/techprogram/paper_41347.htm.

Hamed, K.H., and Rao, A.R., 1998, A Modified Mann-Kendall trend test for autocorrelated data: Journal of Hydrology (Amsterdam), v. 204, no. 1-4, p. 182-196. [Also available at https://doi.org/10.1016/S0022-1694(97)00125-X.]

Hamed, K.H., 2008, Trend detection in hydrologic dataThe Mann-Kendall trend test under the scaling hypothesis: Journal of Hydrology (Amsterdam), v. 349, no. 3-4, p. 350-363. [Also available at https://doi.org/10.1016/j .jhydrol.2007.11.009.]

Helsel, D.R., Hirsch, R.M., Ryberg, K.R., Archfield, S.A., and Gilroy, E.J., 2020, Statistical methods in water resources: U.S. Geological Survey Techniques and Methods, book 4, chapter A3, 458 p. [Also available at https://doi.org/ 10.3133/tm4a3.]

Hansen, D.S., 1990, Water resources of Codington and Grant Counties, South Dakota: U.S. Geological Survey WaterResources Investigations Report 89-4147, 47 p. [Also available at https://pubs.er.usgs.gov/publication/wri894147.]

Hodgkins, G.A., and Dudley, R.W., 2011, Historical summer base flow and stormflow trends for New England rivers: Water Resources Research, v. 47, no. 7. [Also available at https://doi.org/10.1029/2010WR009109.]

Kendall, M.G., 1938, A new measure of rank correlation: Biometrika, v. 30, no. 1-2, p. 81-93. [Also available at https://doi.org/10.1093/biomet/30.1-2.81.] 
Koch, N.C., 1972, Major aquifers and sand and gravel resources in Marshall County, South Dakota: South Dakota Geological Survey Information Pamphlet No. 1, 9 p. [ Also available at http://www.sdgs.usd.edu/pubs/pdf/WIP-01.pdf.]

Koch, N.C., 1975, Geology and water resources of Marshall County, South Dakota: South Dakota Geological Survey Bulletin 23, 76 p. [Also available at http://www.sdg s.usd.edu/pubs/pdf/B-23.pdf.]

Koutsoyiannis, D., and Montanari, A., 2007, Statistical analysis of hydroclimatic time series-Uncertainty and insights: Water Resources Research, v. 43, no. 5. [Also available at https://doi.org/10.1029/2006WR005592.]

Lawrence, S.J., 1989, Water-resources appraisal of the Lake Traverse Indian Reservation in South Dakota: U.S. Geological Survey Water-Resources Investigations Report 88-4031, 42 p. [Also available at https://doi.org/10.3133/ wri884031.]

Leap, D.I., 1972, Major aquifers and sand and gravel resources in Day County, South Dakota: South Dakota Geological Survey Information Pamphlet No. 3, 4 p. [Also available at http://www.sdgs.usd.edu/pubs/pdf/IP-03.pdf.]

Leap, D.I., 1988, Geology and hydrology of Day County, South Dakota: South Dakota Geological Survey Bulletin 24, 117 p. [Also available at http://www.sdgs.usd.edu/pubs/pdf/ B-24.pdf.]

Martin, J.E., Sawyer, F.J., Fahrenbach, M.D., Tomhave, D.W., and Schulz, L.D., 2004, Geologic map of South Dakota: South Dakota Geological Survey, General Map 10, scale 1:500,000, accessed September 12, 2019, at http://www.sdg s.usd.edu/pubs/pdf/G-10.pdf.

Niehus, C.A., Vecchia, A.V., and Thompson, R.F., 1999, Lake-level frequency analysis for the Waubay Lakes Chain, northeastern South Dakota: U.S. Geological Survey Water-Resources Investigations Report 99-4122, 166 p., with appendix. [Also available at https://doi.org/10.3133/ wri994122.]

Önöz, B., and Bayazit, M., 2012, Block bootstrap for MannKendall trend test of serially dependent data: Hydrological Processes, v. 26, no. 23, p. 3552-3560. [Also available at https://doi.org/10.1002/hyp.8438.]

Patakamuri, S.K., 2018, modifiedmk-Modified versions of Mann Kendall and Spearman's Rho trend tests, ver. 1.3.0: accessed March 8, 2019, at https://CRAN.R-project.org/ package $=$ modifiedmk.
Paulson, Q.F., 1953, Ground water in the Fairmount area, Richland County, North Dakota and adjacent areas in Minnesota: North Dakota State Water Conservation Commission, North Dakota Ground-Water Studies No. 22, 67 p., accessed October 31, 2019, at https://www.s wc.nd.gov/info_edu/reports_and_publications/pdfs/gw studies/gws_22_report.pdf.

Powell, J.E., 1956, Geology and groundwater resources of the Hankinson area, Richland County, North Dakota: North Dakota State Water Conservation Commission, North Dakota Ground-Water Studies No. 25, 45 p., accessed October 31, 2019, at https://www.swc.nd.gov/info_edu/ reports_and_publications/pdfs/gw_studies/gws_25 report.pdf.

R Core Team, 2017, R-A language and environment for statistical computing: Vienna, Austria, R Foundation for Statistical Computing, ver. 3.5.1, accessed May 14, 2019, at https://www.R-project.org/.

Sen, P.K., 1968, Estimates of the regression coefficient based on Kendall's tau: Journal of the American Statistical Association, v. 63, no. 324, p. 1379-1389. [Also available at https://doi.org/10.1080/01621459.1968.10480934.]

Sisseton Wahpeton Oyate, 2019, Government: accessed October 31, 2019, at https://www.swo-nsn.gov/government/.

South Dakota Department of Environment and Natural Resources, 2017, Water Rights: South Dakota Department of Environment and Natural Resources database: accessed December 27, 2017, at https://denr.sd.gov/des/wr/ dbwrsearch.aspx.

South Dakota Department of Environment and Natural Resources, 2018, Observation wells: South Dakota Department of Environment and Natural Resources database: accessed October 31, 2018, at https://apps.sd.gov/ nr69obswell/default.aspx.

South Dakota Department of Environment and Natural Resources, 2019a, Summary of SD water laws \& rules: accessed March 1, 2019, at https://denr.sd.gov/des/wr/ summary.aspx.

South Dakota Department of Environment and Natural Resources, 2019b, Measured lakes: South Dakota Department of Environment and Natural Resources database: accessed August 9, 2019, at https://apps.sd.gov/ NR65LakeInfo/public.aspx.

Thompson, R.F., 2001, Water resources of the Lake Traverse Reservation, South and North Dakota, and Roberts County, South Dakota: U.S. Geological Survey Water-Resources Investigation Report 01-4219, 105 p. [Also available at ht tps://pubs.usgs.gov/wri/wri01-4219/.] 
U.S. Department of Agriculture Natural Resources Conservation Service, 2019, Interactive soils map: accessed October 31, 2019, at https://websoilsurvey.sc.egov .usda.gov/App/WebSoilSurvey.aspx.

U.S. Census Bureau, 2018, Cartographic boundary filesShapefile: accessed October 21, 2020, at https://www.c ensus.gov/geographies/mapping-files/time-series/geo/cartoboundary-file.html.

U.S. Geological Survey, 2019, USGS water data for the Nation: U.S. Geological Survey National Water Information System database, accessed October 28, 2019, at https://doi.org/10.5066/F7P55KJN.
Venables, W.N., and Ripley, B.D., 2002, Modern applied statistics with S: New York, Springer-Verlag, 497 p. [Also available at https://doi.org/10.1007/978-0-387-21706-2.]

Wilks, D.S., 2011, Statistical methods in atmospheric sciences (3rd ed.): Waltham, Mass., Oxford, Academic Press, 661 p. [Also available at https://www.elsevier.com/books/ statistical-methods-in-the-atmospheric-sciences/wilks/9780-12-385022-5.]

Winter, D.R., 1994, Water levels through 1989 in bedrock aquifers in South Dakota: U.S. Geological Survey OpenFile Report 94-320, 279 p. [Also available at https://doi.org/ 10.3133/ofr94320.] 
Appendixes 


\section{Appendix 1}

Graphs showing trends in measured water levels for the 76 observation wells considered are shown in figures 1.1 through 1.76 (available at https://doi.org/10.3133/ sir20205151). These figures are ordered by aquifer and include figures 1.1-1.20 for wells completed in the North Big Sioux aquifer, figures 1.21-1.36 for wells completed in the Prairie Coteau outwash group, figures 1.37-1.47 for wells completed in the Coteau Lakes aquifer system, figures $1.48-1.60$ for wells completed in the Veblen aquifer system, figure 1.61 for a well completed in the Middle James aquifer, figures 1.62-1.65 for wells completed in the Fairmount aquifer, figures 1.66-1.68 for wells completed in the Revillo aquifer, figures 1.69-1.71 for wells completed in the Pleistocene aquifer, and figures 1.72-1.76 for wells completed in the Rosholt aquifer. Either two or three graphs are presented for each observation well. Graph $A$ shows individual measurements of groundwater levels for each well and annual total precipitation from the Parameter-elevation Regressions on Independent Slopes Model (PRISM), which is estimated for the location of well. Graph $A$ includes a locally estimated scatterplot smoothing (LOESS) curve that is fit to the time series for annual total precipitation starting 2 years before the first year of waterlevel record for each well, which is used as the first year for trend analyses for the precipitation data. Results of timetrend analyses (Sen's slope and Mann-Kendall $p$-values) are shown above Graph $A$ for three annual water-level parameters (minimum, median, and maximum). Graph $B$ shows the same individual measurements of water levels as in Graph $A$, along with measured water levels for a selected lake. Graph $C$ shows licensed groundwater withdrawals rates, by year, within six specified radii $(0.5,1.0,2.0,3.0,4.0$, and 5.0 miles $)$ of each well. Graph $C$ is not included in cases where there are no known licensed groundwater withdrawals within 5 miles. 


\section{Appendix 2}

Complete results of the modified Mann-Kendall statistical trend tests for water-level measurements and standard MannKendall statistical trend tests for precipitation measurements at observation wells are listed in table 2.1. Two statistical methods were used for analysis of temporal trends for climatic and hydrologic data. To determine which trend analysis to use for statistical significance and magnitudes of temporal trends, applicable datasets were tested for statistically significant short-term persistence (STP) as described in the "Statistical and Analytical Methods" section of the main report. The standard version of the nonparametric Mann-Kendall test was used to determine statistical significance of trends for datasets that showed little or no STP. For datasets with substantial STP, a modified Mann-Kendall test was used. Results of testing for STP for applicable datasets are summarized in table 2.2. Graphs showing autocorrelation function values for annual total precipitation, annual mean maximum temperature, and annual mean minimum temperature for the study area are shown in figure 2.1. Graphs showing autocorrelation function values for annual total precipitation for the study area from 1896 to 2017, 1956 to 2017, and 1975 to 2017 are shown in figure 2.2. Graphs showing autocorrelation function values for annual total precipitation and annual median water levels for the 58 observation wells considered are shown in figures 2.3 through 2.78 . 
[no., number; ft/yr, foot per year; $p$-value, probability value; in/yr, inch per year; $<$, less than]

\begin{tabular}{|c|c|c|c|c|c|c|c|c|c|c|c|c|}
\hline \multirow{3}{*}{$\begin{array}{c}\text { Map } \\
\text { number }\end{array}$} & \multirow{3}{*}{$\begin{array}{c}\text { Well } \\
\text { number }\end{array}$} & \multirow{3}{*}{ Aquifer } & \multirow{3}{*}{$\begin{array}{l}\text { Start } \\
\text { year }\end{array}$} & \multicolumn{9}{|c|}{ Water levels } \\
\hline & & & & \multicolumn{3}{|c|}{ Minimum water level } & \multicolumn{3}{|c|}{ Median water level } & \multicolumn{3}{|c|}{ Maximum water level } \\
\hline & & & & $\begin{array}{c}\text { Sen's Slope } \\
\text { (ft/yr) }\end{array}$ & $\begin{array}{c}\text { Mod M-K } \\
p \text {-value }\end{array}$ & $\begin{array}{c}\text { Mod M-K } \\
\text { tau }\end{array}$ & $\begin{array}{c}\text { Sen's Slope } \\
\text { (ft/yr) }\end{array}$ & $\begin{array}{c}\text { Mod M-K } \\
p \text {-value }\end{array}$ & $\begin{array}{c}\text { Mod M-K } \\
\text { tau }\end{array}$ & $\begin{array}{c}\text { Sen's Slope } \\
\text { (ft/yr) }\end{array}$ & $\begin{array}{c}\text { Mod M-K } \\
p \text {-value }\end{array}$ & $\begin{array}{c}\text { Mod M-K } \\
\text { tau }\end{array}$ \\
\hline 1 & CD-56A & North Big Sioux & 1957 & 0.021 & 0.002 & 0.319 & 0.020 & $<0.001$ & 0.313 & 0.033 & $<0.001$ & 0.390 \\
\hline 2 & CD-57A & North Big Sioux & 1957 & 0.100 & $<0.001$ & 0.390 & 0.113 & $<0.001$ & 0.402 & 0.120 & $<0.001$ & 0.409 \\
\hline 3 & CD-59A & North Big Sioux & 1960 & 0.044 & 0.006 & 0.340 & 0.052 & 0.003 & 0.404 & 0.046 & 0.020 & 0.316 \\
\hline 4 & CD-60A & North Big Sioux & 1960 & 0.008 & 0.495 & 0.076 & 0.014 & 0.254 & 0.134 & 0.015 & 0.373 & 0.110 \\
\hline 5 & CD-60B & North Big Sioux & 1960 & -0.053 & $<0.001$ & -0.450 & -0.057 & $<0.001$ & -0.439 & -0.044 & 0.007 & -0.379 \\
\hline 6 & CD-76A & Prairie Coteau & 1977 & -0.477 & 0.005 & -0.328 & -0.064 & 0.343 & -0.130 & 0.018 & 0.382 & 0.135 \\
\hline 7 & CD-76B & North Big Sioux & 1977 & -0.031 & 0.013 & -0.357 & -0.035 & 0.024 & -0.312 & -0.048 & 0.018 & -0.343 \\
\hline 8 & CD-76C & North Big Sioux & 1977 & 0.015 & 0.120 & 0.176 & 0.001 & 0.787 & 0.032 & -0.003 & 0.515 & -0.034 \\
\hline 9 & CD-76D & Prairie Coteau & 1976 & -0.757 & 0.028 & -0.336 & -0.044 & 0.658 & -0.063 & 0.005 & 0.851 & 0.030 \\
\hline 10 & $\mathrm{CD}-77 \mathrm{~A}$ & Prairie Coteau & 1981 & -0.045 & 0.399 & -0.132 & 0.092 & 0.082 & 0.259 & 0.076 & 0.070 & 0.268 \\
\hline 11 & CD-77B & North Big Sioux & 1978 & 0.004 & 0.723 & 0.055 & -0.003 & 0.890 & -0.023 & -0.010 & 0.651 & -0.064 \\
\hline 12 & $\mathrm{CD}-77 \mathrm{C}$ & North Big Sioux & 1978 & 0.006 & 0.803 & 0.041 & 0.005 & 0.852 & 0.032 & 0.004 & 0.898 & 0.021 \\
\hline 13 & $\mathrm{CD}-77 \mathrm{~F}$ & North Big Sioux & 1978 & 0.015 & 0.582 & 0.072 & 0.009 & 0.820 & 0.032 & -0.004 & 0.901 & -0.019 \\
\hline 14 & CD-79A & North Big Sioux & 1980 & -0.013 & 0.637 & -0.053 & -0.006 & 0.869 & -0.027 & 0.000 & 1.000 & -0.001 \\
\hline 15 & CD-81A & North Big Sioux & 1981 & 0.051 & 0.117 & 0.255 & 0.068 & 0.055 & 0.321 & 0.055 & 0.047 & 0.308 \\
\hline 16 & CD-81B & North Big Sioux & 1981 & 0.052 & 0.207 & 0.191 & 0.057 & 0.100 & 0.228 & 0.032 & 0.300 & 0.149 \\
\hline 17 & CD-89A & North Big Sioux & 1989 & 0.012 & 0.548 & 0.071 & 0.016 & 0.615 & 0.071 & 0.007 & 0.905 & 0.020 \\
\hline 18 & CD-89B & North Big Sioux & 1989 & -0.012 & 0.491 & -0.074 & -0.014 & 0.610 & -0.059 & -0.017 & 0.589 & -0.084 \\
\hline 19 & DA-78C & Couteau Lakes & 1978 & 0.297 & 0.068 & 0.306 & 0.585 & 0.003 & 0.578 & 0.599 & $<0.001$ & 0.705 \\
\hline 20 & DA-78D & Couteau Lakes & 1978 & 0.146 & 0.006 & 0.508 & 0.099 & 0.007 & 0.518 & 0.076 & 0.006 & 0.518 \\
\hline 21 & DA-78E & Prairie Coteau & 1978 & 0.564 & $<0.001$ & 0.767 & 0.486 & $<0.001$ & 0.778 & 0.467 & $<0.001$ & 0.796 \\
\hline 22 & DA-78F & Prairie Coteau & 1978 & 0.438 & $<0.001$ & 0.703 & 0.401 & $<0.001$ & 0.754 & 0.382 & $<0.001$ & 0.767 \\
\hline 23 & DA-78H & Prairie Coteau & 1979 & 0.386 & $<0.001$ & 0.749 & 0.393 & $<0.001$ & 0.752 & 0.401 & $<0.001$ & 0.773 \\
\hline 24 & DA-82C & Prairie Coteau & 1982 & 0.303 & 0.099 & 0.333 & 0.268 & 0.101 & 0.324 & 0.244 & 0.164 & 0.271 \\
\hline 25 & GT-57A & North Big Sioux & 1957 & 0.031 & $<0.001$ & 0.344 & 0.037 & $<0.001$ & 0.338 & 0.050 & $<0.001$ & 0.251 \\
\hline 26 & GT-76A & North Big Sioux & 1977 & -0.024 & 0.219 & -0.162 & -0.006 & 0.630 & -0.052 & 0.013 & 0.567 & 0.071 \\
\hline 27 & GT-76B & Prairie Coteau & 1977 & -0.411 & 0.158 & -0.198 & -0.054 & 0.615 & -0.070 & 0.028 & 0.450 & 0.116 \\
\hline 28 & GT-76C & Prairie Coteau & 1977 & -0.388 & 0.072 & -0.232 & -0.031 & 0.796 & -0.038 & 0.061 & 0.260 & 0.191 \\
\hline 29 & GT-77A & Prairie Coteau & 1977 & -0.400 & 0.141 & -0.243 & -0.069 & 0.524 & -0.094 & 0.045 & 0.369 & 0.155 \\
\hline
\end{tabular}


Table 2.1. Results of statistical trend analyses for groundwater levels estimates at observation wells.-Continued

[no., number; ft/yr, foot per year; $p$-value, probability value; in/yr, inch per year; $<$, less than]

\begin{tabular}{|c|c|c|c|c|c|c|c|c|c|c|c|c|}
\hline \multirow{3}{*}{$\begin{array}{c}\text { Map } \\
\text { number }\end{array}$} & \multirow{3}{*}{$\begin{array}{c}\text { Well } \\
\text { number }\end{array}$} & \multirow{3}{*}{ Aquifer } & \multirow{3}{*}{$\begin{array}{l}\text { Start } \\
\text { year }\end{array}$} & \multicolumn{9}{|c|}{ Water levels } \\
\hline & & & & \multicolumn{3}{|c|}{ Minimum water level } & \multicolumn{3}{|c|}{ Median water level } & \multicolumn{3}{|c|}{ Maximum water level } \\
\hline & & & & $\begin{array}{c}\text { Sen's Slope } \\
\text { (ft/yr) }\end{array}$ & $\begin{array}{c}\text { Mod M-K } \\
p \text {-value }\end{array}$ & $\begin{array}{l}\text { Mod M-K } \\
\text { tau }\end{array}$ & $\begin{array}{c}\text { Sen's Slope } \\
\text { (ft/yr) }\end{array}$ & $\begin{array}{c}\text { Mod M-K } \\
p \text {-value }\end{array}$ & $\begin{array}{l}\text { Mod M-K } \\
\text { tau }\end{array}$ & $\begin{array}{c}\text { Sen's Slope } \\
\text { (ft/yr) }\end{array}$ & $\begin{array}{c}\text { Mod M-K } \\
p \text {-value }\end{array}$ & $\begin{array}{c}\text { Mod M-K } \\
\text { tau }\end{array}$ \\
\hline 30 & GT-77B & North Big Sioux & 1978 & -0.010 & 0.544 & -0.088 & 0.003 & 0.914 & 0.021 & 0.009 & 0.644 & 0.060 \\
\hline 31 & GT-77C & Prairie Coteau & 1978 & -0.068 & 0.664 & -0.079 & 0.069 & 0.257 & 0.173 & 0.100 & 0.092 & 0.295 \\
\hline 32 & GT-77D & North Big Sioux & 1978 & 0.091 & 0.359 & 0.194 & 0.079 & 0.355 & 0.173 & 0.080 & 0.331 & 0.171 \\
\hline 33 & GT-77E & Prairie Coteau & 1978 & -0.013 & 0.876 & -0.032 & 0.032 & 0.535 & 0.108 & 0.032 & 0.585 & 0.088 \\
\hline 34 & GT-79A & Prairie Coteau & 1982 & -0.100 & 0.419 & -0.143 & 0.034 & 0.773 & 0.057 & 0.069 & 0.441 & 0.148 \\
\hline 35 & GT-79B & Prairie Coteau & 1980 & -0.235 & 0.350 & -0.158 & -0.004 & 0.970 & -0.007 & 0.041 & 0.525 & 0.119 \\
\hline 36 & GT-79C & Prairie Coteau & 1980 & -0.046 & 0.788 & -0.058 & 0.053 & 0.506 & 0.124 & 0.080 & 0.225 & 0.239 \\
\hline 37 & GT-82A & North Big Sioux & 1982 & 0.008 & 0.468 & 0.103 & -0.009 & 0.363 & -0.095 & -0.009 & 0.548 & -0.071 \\
\hline 38 & ML-69A & Veblen & 1970 & 0.511 & 0.001 & 0.677 & 0.528 & 0.001 & 0.671 & 0.545 & $<0.001$ & 0.711 \\
\hline 39 & ML-70A & Veblen & 1977 & 0.720 & $<0.001$ & 0.843 & 0.721 & $<0.001$ & 0.846 & 0.722 & $<0.001$ & 0.846 \\
\hline 40 & ML-70B & Veblen & 1977 & 0.843 & $<0.001$ & 0.863 & 0.853 & $<0.001$ & 0.867 & 0.859 & $<0.001$ & 0.852 \\
\hline 41 & ML-70C & Middle James & 1977 & 0.052 & 0.142 & 0.245 & 0.050 & 0.137 & 0.232 & 0.039 & 0.261 & 0.183 \\
\hline 42 & ML-70Q & Couteau Lakes & 1978 & 0.132 & 0.128 & 0.323 & 0.155 & 0.058 & 0.351 & 0.162 & 0.069 & 0.328 \\
\hline 43 & RB-76A & Couteau Lakes & 1977 & 0.117 & 0.013 & 0.378 & 0.093 & 0.025 & 0.279 & 0.065 & 0.112 & 0.201 \\
\hline 44 & RB-76B & Couteau Lakes & 1977 & 0.091 & 0.229 & 0.195 & 0.035 & 0.537 & 0.083 & 0.012 & 0.701 & 0.045 \\
\hline 45 & RB-77B & Fairmount & 1977 & 0.136 & 0.056 & 0.333 & 0.200 & 0.042 & 0.382 & 0.220 & 0.019 & 0.443 \\
\hline 46 & RB-77C & Fairmount & 1977 & 0.217 & 0.013 & 0.420 & 0.285 & 0.009 & 0.491 & 0.300 & 0.004 & 0.533 \\
\hline 47 & RB-77D & Rosholt & 1978 & 0.219 & 0.020 & 0.415 & 0.218 & 0.030 & 0.394 & 0.200 & 0.043 & 0.372 \\
\hline 48 & RB-77E & Rosholt & 1978 & 0.302 & 0.060 & 0.360 & 0.312 & 0.032 & 0.387 & 0.275 & 0.043 & 0.376 \\
\hline 49 & $\mathrm{RB}-77 \mathrm{~F}$ & Rosholt & 1978 & 0.362 & $<0.001$ & 0.615 & 0.459 & $<0.001$ & 0.614 & 0.533 & $<0.001$ & 0.638 \\
\hline 50 & RB-77G & Rosholt & 1978 & 0.261 & 0.004 & 0.571 & 0.210 & 0.003 & 0.523 & 0.175 & 0.002 & 0.529 \\
\hline 51 & RB-77I & Fairmount & 1978 & 0.148 & 0.064 & 0.304 & 0.215 & 0.061 & 0.368 & 0.255 & 0.026 & 0.433 \\
\hline 52 & RB-77J & Veblen & 1978 & 0.580 & 0.002 & 0.621 & 0.596 & 0.003 & 0.591 & 0.626 & 0.002 & 0.600 \\
\hline 53 & RB-77K & Rosholt & 1978 & 0.606 & 0.001 & 0.656 & 0.605 & 0.001 & 0.638 & 0.646 & 0.001 & 0.650 \\
\hline 54 & RB-77L & Revillo & 1978 & 0.128 & 0.062 & 0.272 & 0.096 & 0.066 & 0.333 & 0.100 & 0.011 & 0.468 \\
\hline 55 & RB-77M & Revillo & 1978 & 0.254 & $<0.001$ & 0.462 & 0.250 & $<0.001$ & 0.708 & 0.246 & $<0.001$ & 0.765 \\
\hline 56 & $\mathrm{RB}-77 \mathrm{~N}$ & Revillo & 1978 & 0.232 & 0.013 & 0.326 & 0.232 & $<0.001$ & 0.669 & 0.230 & $<0.001$ & 0.772 \\
\hline 57 & RB-77R & Couteau Lakes & 1978 & 0.037 & 0.045 & 0.272 & 0.024 & 0.321 & 0.127 & 0.015 & 0.658 & 0.067 \\
\hline 58 & RB-77S & Couteau Lakes & 1978 & 0.040 & 0.013 & 0.394 & 0.033 & 0.005 & 0.388 & 0.027 & 0.006 & 0.318 \\
\hline
\end{tabular}


[no., number; ft/yr, foot per year; $p$-value, probability value; in/yr, inch per year; <, less than]

\begin{tabular}{|c|c|c|c|c|c|c|c|c|c|c|c|c|}
\hline \multirow{3}{*}{$\begin{array}{c}\text { Map } \\
\text { number }\end{array}$} & \multirow{3}{*}{$\begin{array}{c}\text { Well } \\
\text { number }\end{array}$} & \multirow{3}{*}{ Aquifer } & \multirow{3}{*}{$\begin{array}{l}\text { Start } \\
\text { year }\end{array}$} & \multicolumn{9}{|c|}{ Water levels } \\
\hline & & & & \multicolumn{3}{|c|}{ Minimum water level } & \multicolumn{3}{|c|}{ Median water level } & \multicolumn{3}{|c|}{ Maximum water level } \\
\hline & & & & $\begin{array}{c}\text { Sen's Slope } \\
\text { (ft/yr) }\end{array}$ & $\begin{array}{c}\text { Mod M-K } \\
p \text {-value }\end{array}$ & $\begin{array}{c}\text { Mod M-K } \\
\text { tau }\end{array}$ & $\begin{array}{c}\text { Sen's Slope } \\
\text { (ft/yr) }\end{array}$ & $\begin{array}{c}\text { Mod M-K } \\
p \text {-value }\end{array}$ & $\begin{array}{c}\text { Mod M-K } \\
\text { tau }\end{array}$ & $\begin{array}{c}\text { Sen's Slope } \\
\text { (ft/yr) }\end{array}$ & $\begin{array}{c}\text { Mod M-K } \\
p \text {-value }\end{array}$ & $\begin{array}{c}\text { Mod M-K } \\
\text { tau }\end{array}$ \\
\hline 59 & RB-77T & Couteau Lakes & 1978 & 0.045 & 0.383 & 0.156 & 0.074 & 0.209 & 0.194 & 0.057 & 0.222 & 0.191 \\
\hline 60 & RB-79A & Pleistocene & 1980 & 0.136 & 0.016 & 0.467 & 0.124 & 0.013 & 0.479 & 0.135 & 0.004 & 0.515 \\
\hline 61 & RB-79B & Veblen & 1980 & 0.084 & 0.083 & 0.309 & 0.100 & 0.019 & 0.401 & 0.107 & 0.035 & 0.408 \\
\hline 62 & RB-79C & Veblen & 1980 & 0.131 & 0.053 & 0.333 & 0.117 & 0.175 & 0.255 & 0.101 & 0.025 & 0.384 \\
\hline 63 & RB-79D & Veblen & 1980 & 0.010 & 0.703 & 0.080 & 0.021 & 0.570 & 0.102 & 0.050 & 0.205 & 0.182 \\
\hline 64 & RB-81A & Veblen & 1981 & 0.676 & $<0.001$ & 0.812 & 0.709 & $<0.001$ & 0.815 & 0.729 & $<0.001$ & 0.835 \\
\hline 65 & RB-81C & Couteau Lakes & 1982 & -0.058 & 0.004 & -0.443 & -0.062 & 0.002 & -0.563 & -0.056 & 0.001 & -0.467 \\
\hline 66 & RB-81D & Couteau Lakes & 1982 & 0.122 & 0.086 & 0.321 & 0.101 & 0.034 & 0.217 & 0.100 & 0.205 & 0.206 \\
\hline 67 & RB-82B & Couteau Lakes & 1982 & 0.000 & 0.955 & 0.013 & 0.003 & 0.895 & 0.027 & 0.000 & 0.936 & -0.016 \\
\hline 68 & RB-93C & Prairie Coteau & 1994 & -0.100 & 0.157 & -0.272 & -0.081 & 0.010 & -0.275 & -0.076 & 0.008 & -0.275 \\
\hline 69 & RB-98A & Fairmount & 1998 & -0.769 & 0.315 & -0.221 & -0.603 & 0.074 & -0.295 & -0.431 & 0.118 & -0.305 \\
\hline 70 & RB-\#05 & Pleistocene & 1981 & 0.078 & 0.002 & 0.363 & 0.088 & 0.033 & 0.305 & 0.089 & 0.068 & 0.264 \\
\hline 71 & RB-\#07 & Veblen & 1981 & 0.004 & 0.858 & 0.039 & -0.018 & 0.655 & -0.074 & -0.030 & 0.479 & -0.138 \\
\hline 72 & RB-\#10 & Pleistocene & 1981 & 0.109 & $<0.001$ & 0.429 & 0.134 & 0.001 & 0.467 & 0.134 & $<0.001$ & 0.526 \\
\hline 73 & RB-\#11 & Veblen & 1981 & 0.250 & $<0.001$ & 0.629 & 0.251 & $<0.001$ & 0.640 & 0.257 & $<0.001$ & 0.631 \\
\hline 74 & RB-\#12 & Veblen & 1981 & 0.224 & $<0.001$ & 0.605 & 0.220 & $<0.001$ & 0.581 & 0.215 & $<0.001$ & 0.583 \\
\hline 75 & RB-\#19 & Veblen & 1982 & 0.244 & $<0.001$ & 0.632 & 0.250 & $<0.001$ & 0.576 & 0.243 & $<0.001$ & 0.611 \\
\hline 76 & RB-\#20 & Veblen & 1981 & 0.251 & $<0.001$ & 0.616 & 0.254 & $<0.001$ & 0.631 & 0.247 & $<0.001$ & 0.635 \\
\hline
\end{tabular}


Table 2.2. Results of statistical trend analyses for annual total precipitation estimates at observation wells.

[Start year, start year for statistical analysis; Mod M-K, modified Mann-Kendall; p-value, probability value; M-K, Mann-Kendall; in/yr, inches per year]

\begin{tabular}{|c|c|c|c|c|c|c|}
\hline \multirow[b]{2}{*}{$\begin{array}{c}\text { Map } \\
\text { number }\end{array}$} & \multirow[b]{2}{*}{$\begin{array}{c}\text { Well } \\
\text { number }\end{array}$} & \multirow[b]{2}{*}{ Aquifer } & \multicolumn{4}{|c|}{ Annual total precipitation } \\
\hline & & & $\begin{array}{l}\text { Start } \\
\text { year }\end{array}$ & $\begin{array}{l}\text { Sen's Slope } \\
\text { (in/yr) }\end{array}$ & M-K p-value & M-K tau \\
\hline 1 & CD-56A & North Big Sioux & 1956 & 0.046 & 0.170 & 0.120 \\
\hline 2 & CD-57A & North Big Sioux & 1956 & 0.025 & 0.395 & 0.075 \\
\hline 3 & CD-59A & North Big Sioux & 1958 & 0.050 & 0.124 & 0.137 \\
\hline 4 & CD-60A & North Big Sioux & 1958 & 0.048 & 0.204 & 0.113 \\
\hline 5 & CD-60B & North Big Sioux & 1958 & 0.049 & 0.134 & 0.133 \\
\hline 6 & CD-76A & Prairie Coteau & 1975 & 0.064 & 0.250 & 0.123 \\
\hline 7 & CD-76B & North Big Sioux & 1975 & 0.032 & 0.572 & 0.061 \\
\hline 8 & $\mathrm{CD}-76 \mathrm{C}$ & North Big Sioux & 1975 & 0.041 & 0.426 & 0.085 \\
\hline 9 & CD-76D & Prairie Coteau & 1974 & 0.102 & 0.077 & 0.186 \\
\hline 10 & CD-77A & Prairie Coteau & 1979 & 0.039 & 0.529 & 0.072 \\
\hline 11 & CD-77B & North Big Sioux & 1976 & 0.070 & 0.251 & 0.124 \\
\hline 12 & $\mathrm{CD}-77 \mathrm{C}$ & North Big Sioux & 1976 & 0.066 & 0.251 & 0.124 \\
\hline 13 & $\mathrm{CD}-77 \mathrm{~F}$ & North Big Sioux & 1976 & 0.030 & 0.618 & 0.055 \\
\hline 14 & CD-79A & North Big Sioux & 1978 & 0.040 & 0.584 & 0.062 \\
\hline 15 & CD-81A & North Big Sioux & 1979 & 0.025 & 0.628 & 0.055 \\
\hline 16 & CD-81B & North Big Sioux & 1979 & 0.029 & 0.595 & 0.061 \\
\hline 17 & CD-89A & North Big Sioux & 1987 & 0.092 & 0.455 & 0.097 \\
\hline 18 & CD-89B & North Big Sioux & 1987 & 0.091 & 0.434 & 0.101 \\
\hline 19 & DA-78C & Couteau Lakes & 1976 & 0.150 & 0.009 & 0.282 \\
\hline 20 & DA-78D & Couteau Lakes & 1976 & 0.165 & 0.008 & 0.287 \\
\hline 21 & DA-78E & Prairie Coteau & 1976 & 0.096 & 0.146 & 0.157 \\
\hline 22 & DA-78F & Prairie Coteau & 1976 & 0.104 & 0.141 & 0.159 \\
\hline 23 & DA-78H & Prairie Coteau & 1977 & 0.059 & 0.375 & 0.098 \\
\hline 24 & DA-82C & Prairie Coteau & 1980 & 0.143 & 0.056 & 0.218 \\
\hline 25 & GT-57A & North Big Sioux & 1956 & 0.074 & 0.040 & 0.179 \\
\hline 26 & GT-76A & North Big Sioux & 1975 & 0.081 & 0.127 & 0.163 \\
\hline 27 & GT-76B & Prairie Coteau & 1975 & 0.080 & 0.132 & 0.161 \\
\hline 28 & GT-76C & Prairie Coteau & 1975 & 0.090 & 0.098 & 0.176 \\
\hline 29 & GT-77A & Prairie Coteau & 1975 & 0.085 & 0.132 & 0.161 \\
\hline 30 & GT-77B & North Big Sioux & 1976 & 0.102 & 0.146 & 0.157 \\
\hline 31 & GT-77C & Prairie Coteau & 1976 & 0.086 & 0.209 & 0.136 \\
\hline 32 & GT-77D & North Big Sioux & 1976 & 0.089 & 0.193 & 0.141 \\
\hline 33 & GT-77E & Prairie Coteau & 1976 & 0.091 & 0.242 & 0.127 \\
\hline 34 & GT-79A & Prairie Coteau & 1980 & 0.099 & 0.258 & 0.129 \\
\hline 35 & GT-79B & Prairie Coteau & 1978 & 0.074 & 0.279 & 0.121 \\
\hline 36 & GT-79C & Prairie Coteau & 1978 & 0.069 & 0.258 & 0.126 \\
\hline 37 & GT-82A & North Big Sioux & 1980 & 0.104 & 0.227 & 0.138 \\
\hline 38 & ML-69A & Veblen & 1968 & 0.134 & 0.003 & 0.293 \\
\hline 39 & ML-70A & Veblen & 1975 & 0.155 & 0.018 & 0.251 \\
\hline 40 & ML-70B & Veblen & 1975 & 0.152 & 0.017 & 0.254 \\
\hline
\end{tabular}


Table 2.2. Results of statistical trend analyses for annual total precipitation estimates at observation wells. - Continued

[Start year, start year for statistical analysis; Mod M-K, modified Mann-Kendall; p-value, probability value; M-K, Mann-Kendall; in/yr, inches per year]

\begin{tabular}{|c|c|c|c|c|c|c|}
\hline \multirow{2}{*}{$\begin{array}{c}\text { Map } \\
\text { number }\end{array}$} & \multirow{2}{*}{$\begin{array}{c}\text { Well } \\
\text { number }\end{array}$} & \multirow[b]{2}{*}{ Aquifer } & \multicolumn{4}{|c|}{ Annual total precipitation } \\
\hline & & & $\begin{array}{l}\text { Start } \\
\text { year }\end{array}$ & $\begin{array}{c}\text { Sen's Slope } \\
\text { (in/yr) }\end{array}$ & M-K p-value & M-K tau \\
\hline 41 & ML-70C & Middle James & 1975 & 0.165 & 0.012 & 0.267 \\
\hline 42 & ML-70Q & Couteau Lakes & 1976 & 0.160 & 0.009 & 0.282 \\
\hline 43 & RB-76A & Couteau Lakes & 1975 & 0.135 & 0.047 & 0.212 \\
\hline 44 & RB-76B & Couteau Lakes & 1975 & 0.127 & 0.057 & 0.203 \\
\hline 45 & RB-77B & Fairmount & 1975 & 0.166 & 0.021 & 0.245 \\
\hline 46 & RB-77C & Fairmount & 1975 & 0.170 & 0.013 & 0.265 \\
\hline 47 & RB-77D & Rosholt & 1976 & 0.194 & 0.006 & 0.296 \\
\hline 48 & $\mathrm{RB}-77 \mathrm{E}$ & Rosholt & 1976 & 0.181 & 0.009 & 0.280 \\
\hline 49 & $\mathrm{RB}-77 \mathrm{~F}$ & Rosholt & 1976 & 0.176 & 0.016 & 0.259 \\
\hline 50 & $\mathrm{RB}-77 \mathrm{G}$ & Rosholt & 1976 & 0.187 & 0.009 & 0.280 \\
\hline 51 & RB-77I & Fairmount & 1976 & 0.181 & 0.013 & 0.266 \\
\hline 52 & RB-77J & Veblen & 1976 & 0.181 & 0.013 & 0.266 \\
\hline 53 & RB-77K & Rosholt & 1976 & 0.180 & 0.011 & 0.273 \\
\hline 54 & RB-77L & Revillo & 1976 & 0.157 & 0.029 & 0.236 \\
\hline 55 & RB-77M & Revillo & 1976 & 0.156 & 0.024 & 0.243 \\
\hline 56 & RB-77N & Revillo & 1976 & 0.167 & 0.013 & 0.266 \\
\hline 57 & RB-77R & Couteau Lakes & 1976 & 0.146 & 0.026 & 0.240 \\
\hline 58 & RB-77S & Couteau Lakes & 1976 & 0.122 & 0.099 & 0.178 \\
\hline 59 & RB-77T & Couteau Lakes & 1976 & 0.133 & 0.059 & 0.203 \\
\hline 60 & RB-79A & Pleistocene & 1978 & 0.191 & 0.016 & 0.267 \\
\hline 61 & RB-79B & Veblen & 1978 & 0.196 & 0.013 & 0.274 \\
\hline 62 & RB-79C & Veblen & 1978 & 0.164 & 0.014 & 0.272 \\
\hline 63 & RB-79D & Veblen & 1978 & 0.168 & 0.023 & 0.251 \\
\hline 64 & RB-81A & Veblen & 1979 & 0.232 & 0.003 & 0.328 \\
\hline 65 & RB-81C & Couteau Lakes & 1980 & 0.160 & 0.008 & 0.303 \\
\hline 66 & RB-81D & Couteau Lakes & 1980 & 0.137 & 0.097 & 0.189 \\
\hline 67 & RB-82B & Couteau Lakes & 1980 & 0.147 & 0.029 & 0.249 \\
\hline 68 & RB-93C & Prairie Coteau & 1992 & 0.069 & 0.724 & 0.052 \\
\hline 69 & RB-98A & Fairmount & 1996 & 0.095 & 0.612 & 0.082 \\
\hline 70 & RB-\#05 & Pleistocene & 1979 & 0.182 & 0.008 & 0.298 \\
\hline 71 & RB-\#07 & Veblen & 1979 & 0.183 & 0.010 & 0.287 \\
\hline 72 & RB-\#10 & Pleistocene & 1979 & 0.183 & 0.009 & 0.293 \\
\hline 73 & RB-\#11 & Veblen & 1979 & 0.178 & 0.011 & 0.285 \\
\hline 74 & RB-\#12 & Veblen & 1979 & 0.193 & 0.009 & 0.293 \\
\hline 75 & RB-\#19 & Veblen & 1980 & 0.205 & 0.014 & 0.280 \\
\hline 76 & RB-\#20 & Veblen & 1979 & 0.196 & 0.010 & 0.287 \\
\hline
\end{tabular}


Table 2.3. Results of short-term persistence analyses for annual total precipitation and annual median groundwater levels estimates at observation wells.

[Start year, start year for statistical analysis; STP, short-term persistence]

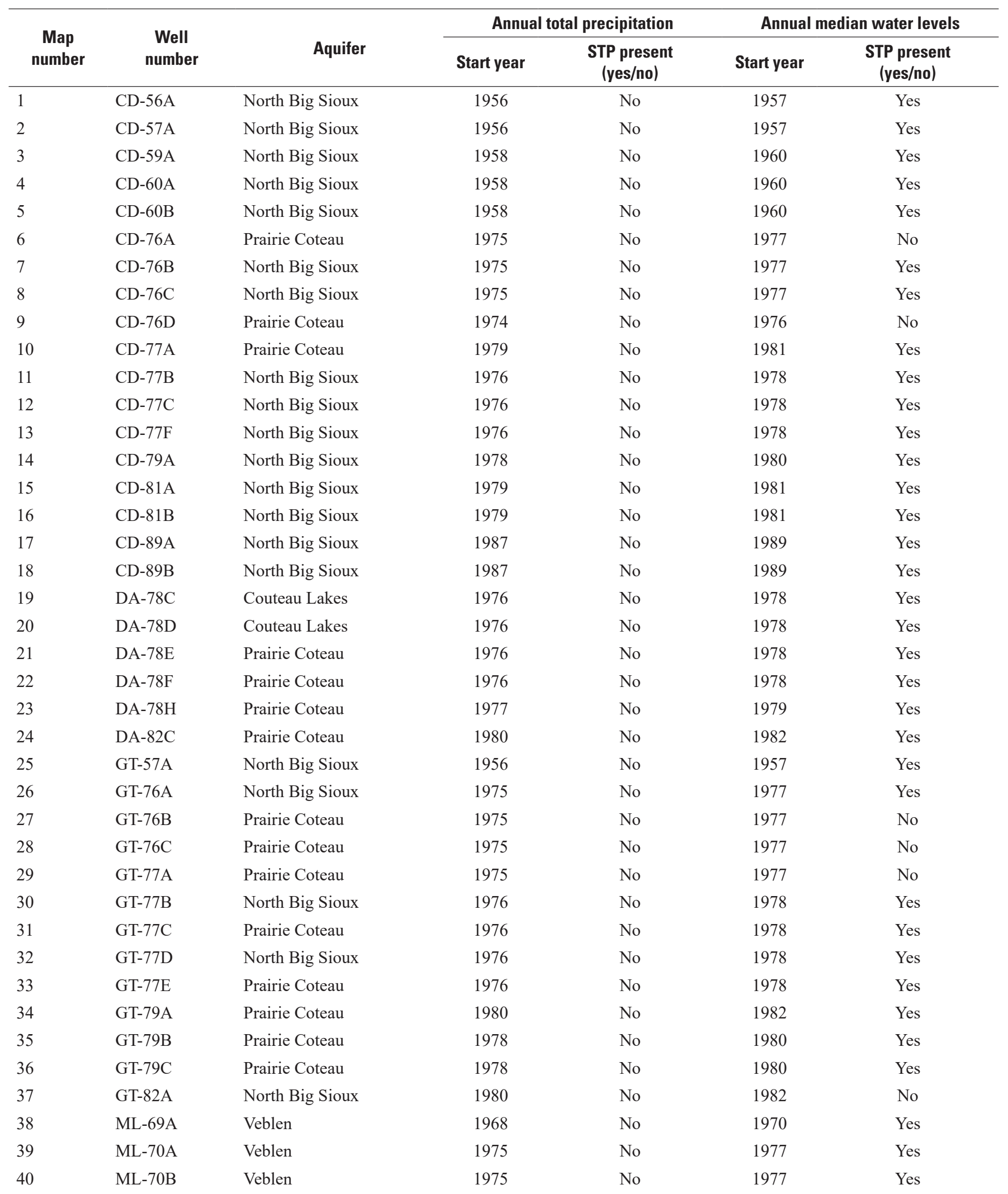


Table 2.3. Results of short-term persistence analyses for annual total precipitation and annual median groundwater levels estimates at observation wells.-Continued

[Start year, start year for statistical analysis; STP, short-term persistence]

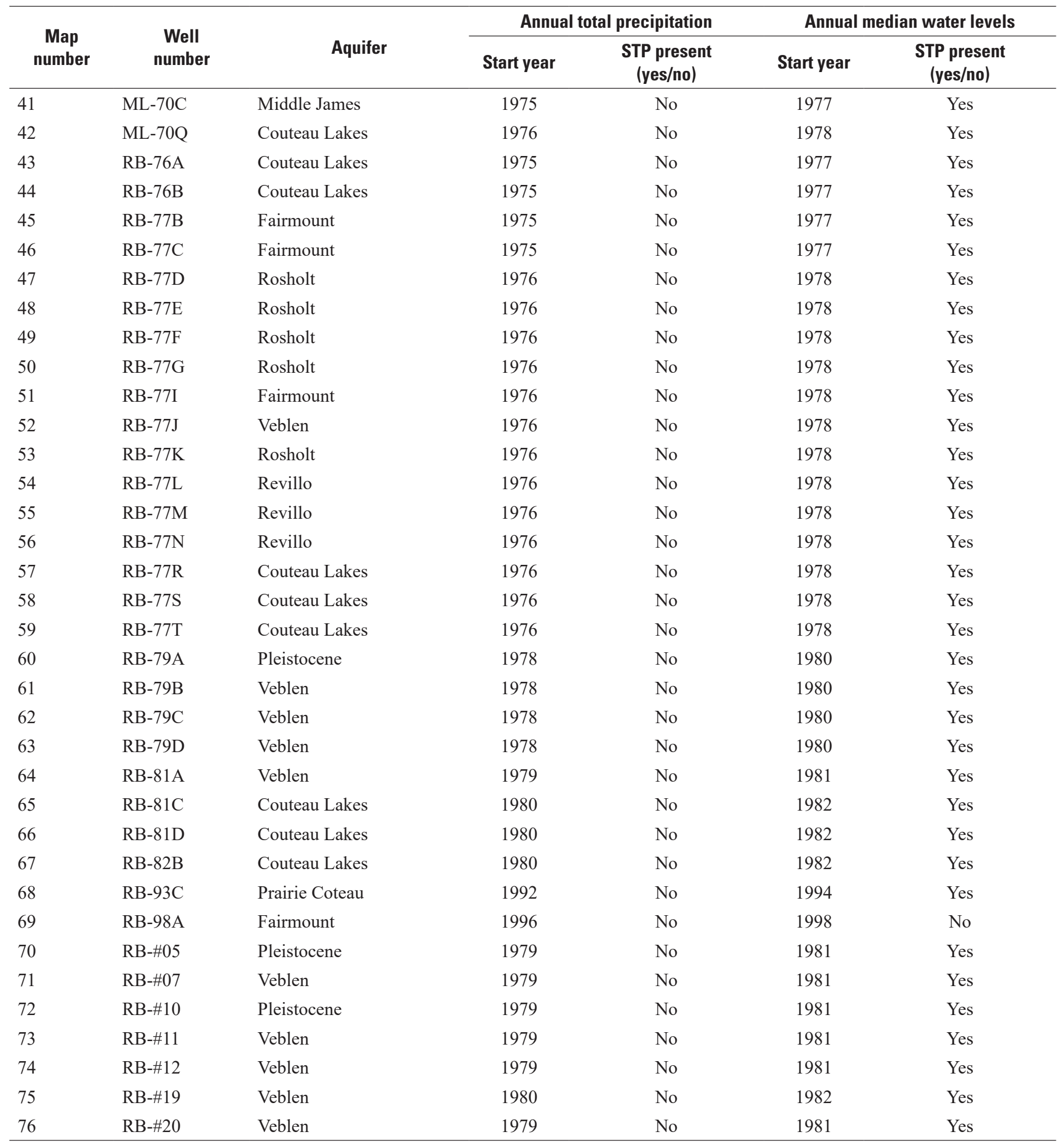


Table 2.4. Summary of licensed groundwater withdrawals within a specified radius of an observation well.

\begin{tabular}{|c|c|c|c|c|c|c|c|}
\hline \multirow{2}{*}{$\begin{array}{c}\text { Map } \\
\text { number }\end{array}$} & \multirow{2}{*}{$\begin{array}{c}\text { Well } \\
\text { number }\end{array}$} & \multicolumn{6}{|c|}{$\begin{array}{l}\text { Licensed groundwater withdrawals, in cubic feet per second, } \\
\text { within specified radius of well, in miles }\end{array}$} \\
\hline & & 0.5 & 1.0 & 2.0 & 3.0 & 4.0 & 5.0 \\
\hline \multicolumn{8}{|c|}{ Observation wells monitoring North Big Sioux aquifer } \\
\hline 1 & CD-56A & 1.0 & 3.8 & 9.2 & 19.8 & 32.4 & 40.2 \\
\hline 2 & CD-57A & 0.0 & 2.7 & 13.1 & 23.0 & 28.4 & 40.7 \\
\hline 3 & CD-59A & 0.0 & 1.6 & 15.5 & 24.5 & 34.7 & 46.5 \\
\hline 4 & CD-60A & 0.0 & 0.0 & 0.4 & 10.8 & 20.2 & 41.3 \\
\hline 5 & CD-60B & 0.0 & 4.9 & 19.7 & 35.4 & 43.5 & 54.5 \\
\hline 7 & CD-76B & 7.1 & 8.0 & 17.8 & 27.9 & 50.3 & 53.4 \\
\hline 8 & CD-76C & 1.9 & 1.9 & 11.8 & 12.8 & 20.1 & 28.1 \\
\hline 11 & CD-77B & 0.0 & 2.7 & 8.6 & 15.2 & 19.6 & 28.0 \\
\hline 12 & CD-77C & 0.0 & 0.0 & 4.4 & 13.2 & 16.6 & 25.4 \\
\hline 13 & CD-77F & 1.3 & 4.2 & 15.9 & 27.1 & 41.1 & 54.3 \\
\hline 14 & CD-79A & 1.7 & 3.3 & 3.3 & 5.0 & 21.1 & 35.0 \\
\hline 15 & CD-81A & 0.0 & 1.8 & 11.1 & 22.1 & 39.5 & 53.2 \\
\hline 16 & CD-81B & 0.0 & 0.0 & 14.2 & 22.9 & 32.0 & 47.1 \\
\hline 17 & CD-89A & 2.9 & 7.3 & 13.1 & 21.2 & 34.0 & 39.4 \\
\hline 18 & CD-89B & 3.3 & 4.4 & 18.1 & 26.0 & 37.4 & 49.9 \\
\hline 25 & GT-57A & 0.0 & 0.0 & 3.3 & 8.2 & 20.3 & 39.5 \\
\hline 26 & GT-76A & 3.5 & 6.6 & 17.8 & 30.8 & 39.2 & 45.8 \\
\hline 30 & GT-77B & 6.2 & 12.1 & 21.8 & 31.8 & 45.3 & 60.4 \\
\hline 32 & GT-77D & 0.7 & 2.8 & 11.3 & 32.6 & 46.8 & 64.0 \\
\hline 37 & GT-82A & 0.0 & 0.0 & 3.3 & 10.4 & 20.3 & 35.2 \\
\hline \multicolumn{8}{|c|}{ Observation wells monitoring Prairie Coteau aquifer } \\
\hline 6 & CD-76A & 1.8 & 1.8 & 1.8 & 8.7 & 14.6 & 28.4 \\
\hline 9 & CD-76D & 5.9 & 7.9 & 10.8 & 21.0 & 36.7 & 40.2 \\
\hline 10 & CD-77A & 0.0 & 1.1 & 6.2 & 13.6 & 27.2 & 40.5 \\
\hline 21 & DA-78E & 1.1 & 1.1 & 7.8 & 11.6 & 18.0 & 27.6 \\
\hline 22 & DA-78F & 0.0 & 5.6 & 11.6 & 18.0 & 25.1 & 35.8 \\
\hline 23 & DA-78H & 0.0 & 0.0 & 0.0 & 0.0 & 2.2 & 14.0 \\
\hline 24 & DA- $82 C$ & 0.0 & 0.0 & 2.2 & 6.7 & 45.3 & 54.9 \\
\hline 27 & GT-76B & 1.0 & 2.0 & 20.5 & 29.3 & 41.1 & 49.4 \\
\hline 28 & GT-76C & 0.0 & 0.0 & 6.7 & 18.0 & 36.7 & 50.7 \\
\hline 29 & GT-77A & 0.0 & 4.3 & 4.3 & 24.8 & 39.0 & 56.3 \\
\hline 31 & GT-77C & 0.0 & 0.0 & 7.9 & 29.5 & 54.2 & 62.9 \\
\hline 33 & GT-77E & 0.0 & 0.0 & 0.0 & 0.0 & 7.9 & 30.2 \\
\hline 34 & GT-79A & 0.0 & 0.0 & 0.1 & 5.2 & 24.0 & 38.8 \\
\hline 35 & GT-79B & 0.0 & 0.0 & 0.0 & 17.0 & 25.9 & 59.5 \\
\hline 36 & GT-79C & 0.0 & 0.0 & 14.4 & 27.4 & 33.6 & 59.0 \\
\hline 68 & RB-93C & 0.0 & 11.3 & 26.8 & 33.8 & 33.8 & 45.3 \\
\hline \multicolumn{8}{|c|}{ Observation wells monitoring Coteau Lakes aquifer system } \\
\hline 19 & DA-78C & 4.5 & 5.8 & 8.9 & 8.9 & 8.9 & 9.5 \\
\hline 20 & DA-78D & 2.6 & 2.6 & 4.2 & 16.6 & 21.2 & 43.8 \\
\hline 42 & ML-70Q & 0.0 & 0.0 & 0.0 & 0.0 & $<0.1$ & 0.1 \\
\hline
\end{tabular}


Table 2.4. Summary of licensed groundwater withdrawals within a specified radius of an observation well.—Continued

\begin{tabular}{|c|c|c|c|c|c|c|c|}
\hline \multirow{2}{*}{$\begin{array}{c}\text { Map } \\
\text { number }\end{array}$} & \multirow{2}{*}{$\begin{array}{c}\text { Well } \\
\text { number }\end{array}$} & \multicolumn{6}{|c|}{$\begin{array}{l}\text { Licensed groundwater withdrawals, in cubic feet per second, } \\
\text { within specified radius of well, in miles }\end{array}$} \\
\hline & & 0.5 & 1.0 & 2.0 & 3.0 & 4.0 & 5.0 \\
\hline \multicolumn{8}{|c|}{ Observation wells monitoring Coteau Lakes aquifer system-Continued } \\
\hline 43 & RB-76A & 1.0 & 5.0 & 22.5 & 33.8 & 40.9 & 52.6 \\
\hline 44 & RB-76B & 6.3 & 6.3 & 17.0 & 26.8 & 33.8 & 40.9 \\
\hline 57 & RB-77R & 6.9 & 6.9 & 18.4 & 30.9 & 51.0 & 55.4 \\
\hline 58 & RB-77S & 2.2 & 2.2 & 10.2 & 24.4 & 40.0 & 68.5 \\
\hline 59 & RB-77T & 5.8 & 11.7 & 19.5 & 33.8 & 33.8 & 44.9 \\
\hline 65 & RB-81C & 0.0 & 2.9 & 6.2 & 6.2 & 13.8 & 28.8 \\
\hline 66 & RB-81D & 0.0 & 0.0 & 8.0 & 17.5 & 31.2 & 33.8 \\
\hline 67 & RB-82B & 0.0 & 1.8 & 16.6 & 38.2 & 49.2 & 61.8 \\
\hline \multicolumn{8}{|c|}{ Observation wells monitoring Veblen aquifer system } \\
\hline 38 & ML-69A & 0.2 & 0.2 & 0.2 & 1.0 & 2.4 & 3.4 \\
\hline 39 & ML-70A & 0.0 & 0.0 & 0.0 & 0.0 & 0.2 & 0.2 \\
\hline 40 & ML-70B & 0.0 & 0.0 & 0.0 & 0.0 & 0.0 & 0.2 \\
\hline 52 & RB-77J & 0.0 & 0.0 & 0.0 & 0.0 & 0.0 & $<0.1$ \\
\hline 61 & RB-79B & 0.0 & 0.0 & 0.3 & 0.3 & 0.3 & 0.3 \\
\hline 62 & RB-79C & 0.4 & 2.0 & 2.0 & 3.3 & 3.3 & 3.3 \\
\hline 63 & RB-79D & 0.0 & 0.0 & 3.3 & 3.3 & 3.3 & 3.3 \\
\hline 64 & RB-81A & 0.0 & 0.0 & 0.0 & 0.0 & 0.0 & 0.0 \\
\hline 71 & RB-\#07 & 0.0 & 0.0 & 1.3 & 2.4 & 3.3 & 5.6 \\
\hline 73 & RB-\#11 & 0.0 & 0.0 & 1.3 & 3.3 & 3.3 & 3.3 \\
\hline 74 & RB-\#12 & 1.3 & 1.3 & 3.3 & 3.3 & 3.3 & 4.9 \\
\hline 75 & RB-\#19 & 0.0 & 1.3 & 3.3 & 3.3 & 3.3 & 3.3 \\
\hline 76 & RB-\#20 & 0.0 & 2.0 & 3.3 & 3.3 & 3.3 & 3.3 \\
\hline \multicolumn{8}{|c|}{ Observation wells monitoring Middle James aquifer } \\
\hline 41 & ML-70C & 0.0 & 0.0 & 0.0 & 0.0 & 0.0 & 0.0 \\
\hline \multicolumn{8}{|c|}{ Observation wells monitoring Fairmount aquifer } \\
\hline 45 & RB-77B & 0.0 & 0.0 & 0.0 & 0.0 & $<0.1$ & $<0.1$ \\
\hline 46 & $\mathrm{RB}-77 \mathrm{C}$ & 0.0 & 0.0 & 0.0 & 0.0 & 0.0 & $<0.1$ \\
\hline 51 & RB-77I & 0.0 & 0.0 & 0.0 & 0.0 & 0.0 & $<0.1$ \\
\hline 69 & RB-98A & 1.6 & 1.9 & 2.7 & 2.7 & 2.7 & 2.7 \\
\hline \multicolumn{8}{|c|}{ Observation wells monitoring Revillo aquifer } \\
\hline 54 & RB-77L & 0.0 & 0.0 & 7.0 & 12.9 & 21.3 & 24.3 \\
\hline 55 & $\mathrm{RB}-77 \mathrm{M}$ & 1.4 & 7.0 & 17.3 & 22.6 & 24.3 & 26.2 \\
\hline 56 & $\mathrm{RB}-77 \mathrm{~N}$ & 0.0 & 9.2 & 13.3 & 19.4 & 22.2 & 28.0 \\
\hline \multicolumn{8}{|c|}{ Observation wells monitoring Pleistocene aquifer } \\
\hline 60 & RB-79A & 0.2 & 0.2 & 0.3 & 0.3 & 0.3 & 0.3 \\
\hline 70 & RB-\#05 & 0.0 & 0.0 & 0.0 & 0.0 & 1.5 & 4.3 \\
\hline 72 & RB-\#10 & 0.0 & 1.3 & 1.3 & 3.3 & 4.8 & 6.8 \\
\hline \multicolumn{8}{|c|}{ Observation wells monitoring Rosholt aquifer } \\
\hline 47 & RB-77D & 0.0 & 1.6 & 2.7 & 2.7 & 2.7 & 2.7 \\
\hline 48 & RB-77E & $<0.1$ & $<0.1$ & $<0.1$ & 1.6 & 2.7 & 2.7 \\
\hline 49 & $\mathrm{RB}-77 \mathrm{~F}$ & 0.0 & 0.0 & 0.0 & $<0.1$ & $<0.1$ & 1.6 \\
\hline 50 & RB-77G & 0.0 & 0.0 & 0.0 & $<0.1$ & 1.6 & 2.7 \\
\hline 53 & $\mathrm{RB}-77 \mathrm{~K}$ & 0.0 & 0.0 & 0.0 & 0.0 & 0.0 & 0.0 \\
\hline
\end{tabular}


For more information about this publication, contact:

Director, USGS Dakota Water Science Center

821 East Interstate Avenue, Bismarck, ND 58503

1608 Mountain View Road, Rapid City, SD 57702

605-394-3200

For additional information, visit: https://www.usgs.gov/centers/ dakotawater

Publishing support provided by the

Rolla Publishing Service Center 
